\begin{abstract}
Aus dem
Veterinär-Physiologisch-Chemischen Institut der Veterinärmedizinischen Fakultät der Universität Leipzig
\end{abstract}

Die Wirkung mehrfach ungesättigter Fettsäuren auf Schlüsselproteine der Knorpeldegeneration in einem Modellsystem für die canine Osteoarthrose

\author{
Inaugural-Dissertation \\ zur Erlangung des Grades eines \\ Doctor medicinae veterinariae (Dr. med. vet.) \\ durch die Veterinärmedizinische Fakultät \\ der Universität Leipzig
}

eingereicht von

Nadja Adler

aus Jena

Leipzig, 2020 
Mit Genehmigung der Veterinärmedizinischen Fakultät der Universität Leipzig

Dekan: $\quad$ Prof. Dr. Dr. Thomas Vahlenkamp

Betreuer: $\quad$ Prof. Dr. Herbert Fuhrmann

Gutachter: $\quad$ Prof. Dr. Herbert Fuhrmann

Veterinär-Physiologisch-Chemisches Institut,

Veterinärmedizinische Fakultät, Universität Leipzig

Prof. Dr. Peter Böttcher

Klinik für kleine Haustiere,

Veterinärmedizinische Fakultät, Freie Universität Berlin

Tag der Verteidigung: 20.11.2020 
Für meine Großeltern

Marlene und Andreas Deutrich

und

Renate und Gerhard Adler 


\section{INHALTSVERZEICHNIS}

$1 \quad$ Einleitung. 1

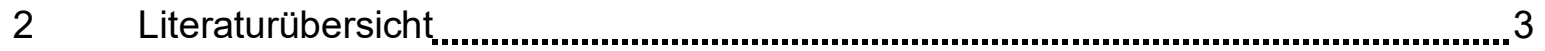

2.1 Physiologie und Anatomie des hyalinen Knorpels....................................

2.1.1 Feinstruktur des Gewebes ...............................................................

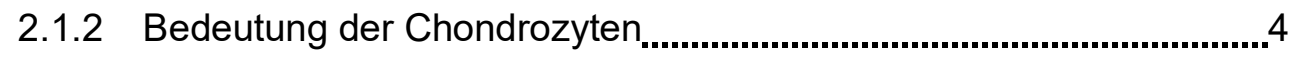

2.1.3 Aufbau der Extrazellulären Matrix (ECM) .................................... 5

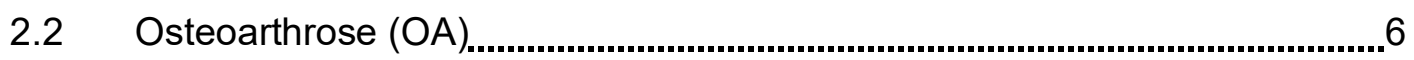

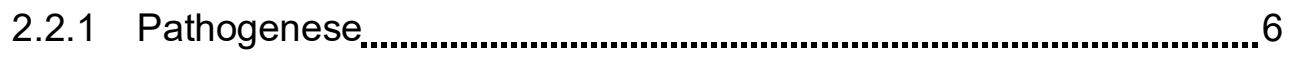

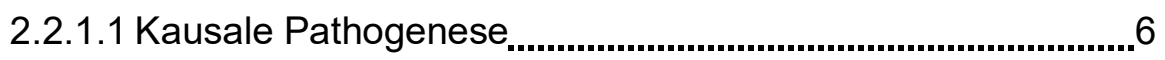

2.2.1.2 Formale Pathogenese

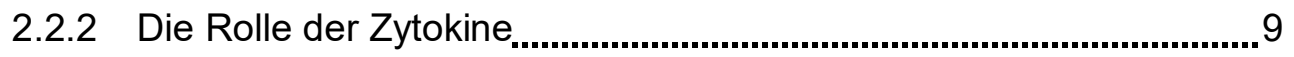

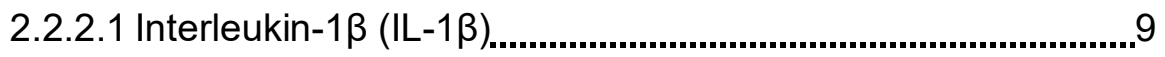

2.2.2.2 Transforming Growth Factor- $\beta$ (TGF- $\beta$ )..............................10

2.2.3 Rolle der Matrixproteinasen MMP und ADAMTS .............................12

2.2.4 Rolle der Entzündungsmediatoren ............................................... 14

2.2.4.1 Stickstoffmonoxid (NO) ........................................................ 14

2.2.4.2 Prostaglandin E2 (PGE2) .................................................... 15

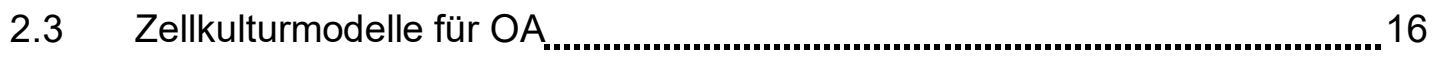

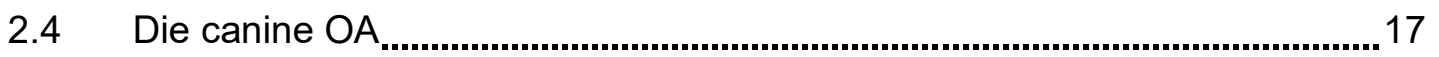

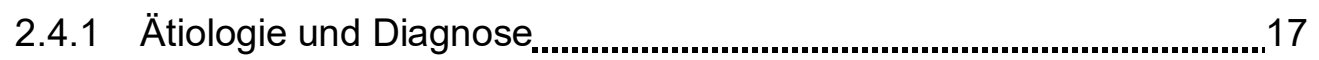

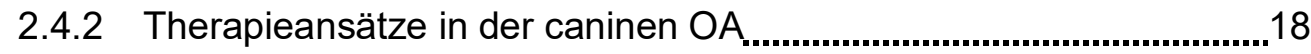

2.5 Mehrfach ungesättigte Fettsäuren (PUFAs) als Ergänzungsfuttermittel.......20

2.5.1 Grundlagen des Fettsäurestoffwechsels ......................................20 
2.5.2 Fettsäurestoffwechsel im Knorpelgewebe .......................................21

2.5.3 n-3 PUFAs als Therapieoption bei caniner OA ................................22

$3 \quad$ Ziel der Arbeit

Ergebnisse

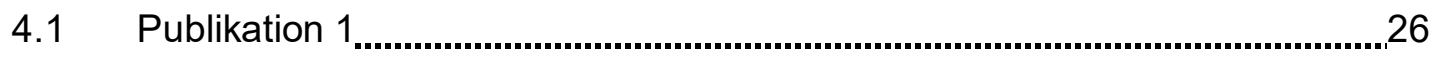

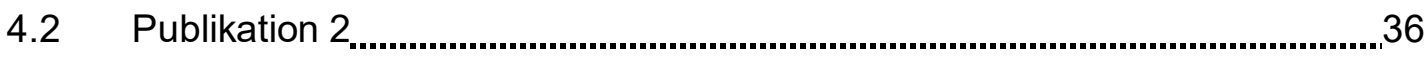

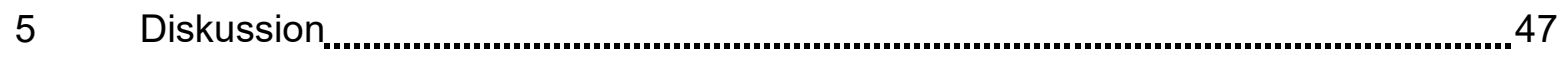

5.1 Isolation und Anzucht von caninen Chondrozyten .....................................4

5.2 IL-stimulierte canine Chondrozyten als Osteoarthrosemodell...................... 51

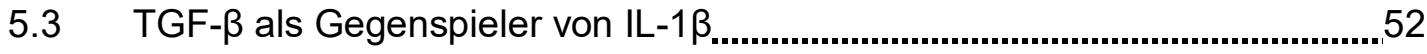

5.4 Fettsäuremetabolismus der Chondrozyten ..................................................5

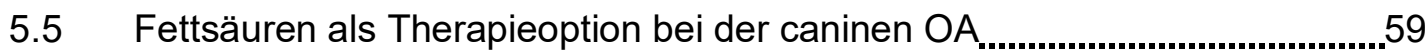

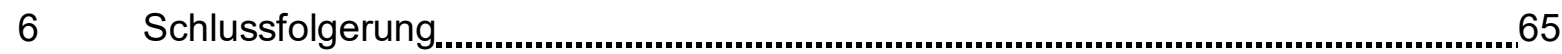

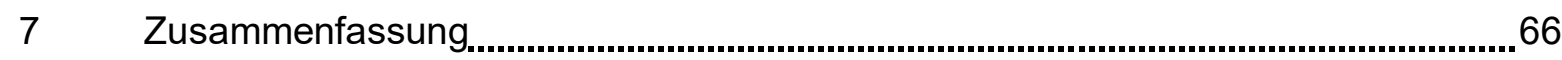

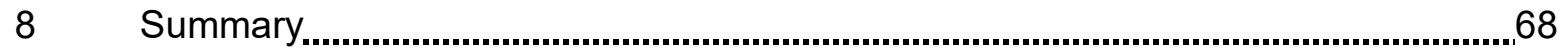

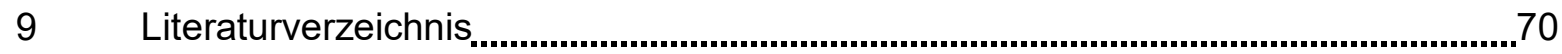

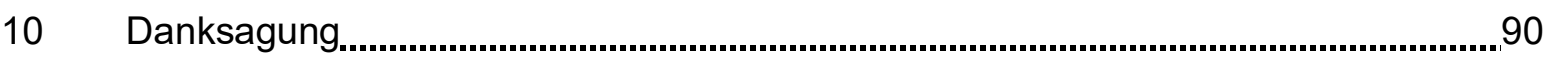




\section{ABBILDUNGSVERZEICHIS}

Abbildung 1: Histologischer Schnitt durch porcinen hyalinen Knorpel (Hämatoxylin-Eosin Färbung). Anhand der Zellmorphologie und Ausrichtung ist die Gliederung in die verschiedenen Zonen deutlich zu erkennen: Tangentialzone $(A)$, Übergangszone $(B)$, Radiärzone (C) und Verkalkungszone (D). (Bild aus der virtuellen Mikroskopie mit freundlicher Genehmigung von Prof. Dr. Johannes Seeger, Universität Leipzig). 4

Abbildung 2: Histologischer Schnitt durch porcinen hyalinen Knorpel (Hämatoxylin-Eosin Färbung). Mehrere Chondrozyten liegen als sogenannte Territorien oder Chondrone abgekapselt in der extrazellulären Matrix. (Bild aus der virtuellen Mikroskopie mit freundlicher Genehmigung von Prof. Dr. Johannes Seeger, Universität Leipzig). 5

Abbildung 3: Strukturformeln der n-3 und n-6 Fettsäuren, welche in dieser Arbeit zur Verwendung kamen. 21

Abbildung 4: Blick auf die Gelenksfläche eines kniegesunden Spenderhundes vor der Gewebsentnahme. 48

Abbildung 5: Chondrozytennester in einer P1-Kultur nach 8 Tagen, dargestellt bei 400 -facher Vergrößerung im Lichtmikroskop. 49

Abbildung 6: Lipidvakuolen in Chondrozyten nach einer Supplementierung des Mediums mit $200 \mu \mathrm{M}$ ALA über 8 Tage, dargestellt mittels Öl Rot O Färbung bei 400-facher Vergrößerung im Lichtmikroskop. 58 


\section{ABKÜRZUNGSVERZEICHNIS}

AA

ADAMTS

ALA

DHA

DNA

DPA

COX

ECM

EPA

FCS

IL-1 $\beta$

LA

LOX

mRNA

miRNA

MMP

NO

NOS

NSAIDs

$\mathrm{OA}$

$P G$

PLA2

PUFA

mRNA

ROS

TGF- $\beta$

TIMP

TNF- $\alpha$
Arachidonsäure

A Disintegrin and Metalloproteinase with Thrombospondin Motifs

Alpha-Linolensäure

Docosahexaensäure

Desoxyribonucleinsäure

Docosapentaensäure

Cyclooxygenase

Extrazelluläre Matrix

Eicosapentaensäure

Fetales Kälberserum

Interleukin-1 $\beta$

Linolsäure

Lipoxygenase

Messenger Ribonukleinsäure

Mikro-Ribonucleinsäure

Matrixmetalloproteinase

Stickstoffmonoxid

Stickstoffmonoxid Synthase

Nichtsteroidale Antiphlogistica

Osteoarthrose

Prostaglandin

Phospholipase A2

Mehrfach ungesättigte Fettsäure

Messenger Ribonukleinsäure

Reaktive Sauerstoffspezies

Transforming Growth Factor- $\beta$

Tissue Inhibitor of Metalloproteinase

Tumor Nekrose Faktor- $\alpha$ 


\section{EINLEITUNG}

Osteoarthrose $(\mathrm{OA})$ ist eine schmerzhafte chronische Gelenkserkrankung, die durch den degenerativen Verlust von Knorpelgewebe auf den Gelenksflächen gekennzeichnet ist (XIA et al. 2014; HOUARD et al. 2013). Geschätzt haben bis zu $20 \%$ der Hunde, die älter als ein Jahr sind, bereits Anzeichen für OA. Damit handelt es sich um die meist diagnostizierte Erkrankung im caninen muskuloskelettalen System (ANDERSON et al. 2018). Symptome der Krankheit wie Lahmheit, Steifheit und Bewegungsschmerz hindern die Tiere daran, Aktivitäten wie Spielen oder langen Spaziergänge nachzugehen und beeinträchtigen daher in einem hohen Maß die Lebensqualität betroffener Hunde (BLAND 2015). Knorpelgewebe ist nicht zur Selbstheilung befähigt, da Chondrozyten ihre Teilungsfähigkeit im Reifungsprozess des Gewebes verlieren und von der Umgebung durch eine dichte extrazelluläre Matrix (ECM) isoliert sind (TEMENOFF und MIKOS 2000; TALLHEDEN et al. 2006). Daher existiert derzeit kein Therapieansatz, welcher zu einem Ersatz des verloren gegangenen Knorpelgewebes führt. Die Behandlung zielt daher auf eine Minderung der klinischen Symptome und eine Verlangsamung der Krankheit. Mittel der ersten Wahl sind in der Tiermedizin nichtsteroidale Antiphlogistika (ANDERSON et al. 2018; BOUND et al. 2011), welche durch eine Hemmung der Cyclooxygenase-2 (COX-2) die Ausschüttung proinflammatorischer Eicosanoide reduzieren und somit den Schmerz und die Entzündung im Gelenk unterdrücken (SMITH et al. 2011). Ein wesentlicher Nachteil dieser Wirkstoffgruppe sind die schädlichen Nebenwirkungen wie gastrointestinale Blutungen und Leber- und Nierenversagen, welche gerade bei der Langzeitanwendung auftreten können (MONTEIRO-STEAGALL et al. 2013). Es besteht daher ein dringender Bedarf an alternativen Wirkstoffen zur Behandlung der caninen OA.

Um neue Therapieoptionen ausfindig zu machen, ist eine Kenntnis der genauen Pathogenese der Krankheit unabdingbar. Die Integrität von Knorpelgewebe wird bestimmt durch das Gleichgewicht zwischen katabolen und anabolen Prozessen. Im Falle der OA kommt es zu einer Störung dieses Gleichgewichts mit einer Verschiebung zu katabolen Prozessen, welche initial durch eine erhöhte Ausschüttung proinflammatorischer Zytokine wie Interleukin-1 $\beta$ (IL-1 $\beta$ ) oder Tumor Nekrose Faktor- $\alpha$ (TNF- $\alpha$ ) angetrieben werden (HOUARD et al. 2013). Diese Zytokine bewirken über eine Regulation der Genexpression die Bildung von Matrixproteinasen und Entzündungsmediatoren sowie Substanzen, welche eine Apoptose der Chondrozyten auslösen (WOJDASIEWICZ et al. 2014). Der genaue Ablauf gilt als multifaktoriell und äußerst komplex, sodass trotz weitreichender Forschung auf diesem Gebiet viele Abläufe unklar sind und die Rollen von bestimmten Faktoren, wie zum Beispiel 
Transforming Growth Faktor- $\beta$ (TGF- $\beta$ ), nicht vollständig geklärt sind (BAUGÉ et al. 2014; XIA et al. 2014).

Die n-3 mehrfach ungesättigten Fettsäuren (PUFAs) Docosahexaensäure (DHA) und Eicosapentaensäure (EPA) aus marinen Nahrungsquellen haben bei einer Vielzahl von chronischen Erkrankungen bei Menschen und Tieren eine entzündungshemmende Wirkung (CALDER 2015). Auch in der caninen OA konnten in mehreren Fütterungsstudien mit n-3 PUFAs eine Besserung der klinischen Symptome beobachtet werden (MEHLER et al. 2016; ROUSH et al. 2010a; ROUSH et al. 2010b; FRITSCH et al. 2010a). Darüber hinaus ermöglichte eine Supplementierung mit Fischöl, die Dosis der NSAIDs zu reduzieren und senkte somit das Risiko von schädlichen Nebenwirkungen (FRITSCH et al. 2010b). Trotz dieser vielversprechenden Ergebnisse existieren bisher kaum Studien, welche den dahinter liegenden Wirkmechanismus aufdecken. In vitro Kulturen aus humanen und bovinen Knorpelzellen weisen eine geringere Produktion von Prostaglandin E (PGE) und proinflammatorischen Zytokinen, sowie eine geringere Matrixdegeneration unter einer Supplementierung von n-3 PUFAs auf (WANN et al. 2010; ZAINAL et al. 2009; HURST et al. 2009; CURTIS et al. 2002b; CURTIS et al. 2002a). Es gilt darüber hinaus als gesichert, dass die EPA und DHA (n-3) mit Arachidonsäure (AA; n-6) um einen Einbau in die Membranphospholipide der Zellen konkurrieren und dort bei einer Umsetzung durch die COX und Lipoxygenase (LOX) zu einem Anstieg an weniger inflammatorischen oder sogar antiinflammatorischen Lipidmediatoren führen (CALDER 2015; WEYLANDT et al. 2012; SMITH et al. 2011).

Die Ergebnisse dieser bisherigen Studien legen nahe, dass bei einem multimodalen Therapieansatz mit n-3 PUFAs zusätzlich zu traditionellen medikamentösen Therapieformen bessere Heilungschancen für die erkrankten Gelenke bestehen. Allerdings untersuchen viele dieser Studien hohe, eventuell sogar supraphysiologische Konzentrationen von n-3 PUFAs (ZAINAL et al. 2009; CURTIS et al. 2002b; CURTIS et al. 2002a). Da sich außerdem der Fettsäuremetabolismus zwischen den einzelnen Tierarten unterscheidet, ist auch ein abweichender Wirkmechanismus zwischen den verschiedenen Tierarten denkbar (BAUER 2008). Die Untersuchungen an Menschen und Rindern können somit nicht ohne Weiteres auf den Hund übertragen werden.

Daher haben wir es uns zum Ziel gesetzt, in dieser Studie die Langzeitwirkung von den n-3 PUFAs EPA und DHA im Vergleich zu der n-6 PUFA AA auf Schlüsselfaktoren der Knorpeldegeneration in einem in vitro Modell der caninen OA zu untersuchen. Im Zuge der Studie wurden darüber hinaus neue Erkenntnisse zur Rolle von IL-1 $\beta$ und TGF- $\beta$ in der caninen OA gewonnen. 


\section{LITERATURÜBERSICHT}

\subsection{Physiologie und Anatomie des hyalinen Knorpels}

Hyaliner Knorpel bedeckt die Gelenkflächen von Säugetieren und besteht aus extrazellulärer Matrix (ECM) und wenigen, hochspezialisierten Zellen, den Chondrozyten. Gesunder hyaliner Knorpel ist ein avaskuläres und alymphatisches Gewebe ohne eine sensible Innervation. Bedingt durch die geringe Versorgungsrate hat das Gewebe eine geringe metabolische Aktivität und kaum Möglichkeiten zur Selbstheilung (PFANDER 2005). Beim Menschen unterliegt der Knorpel Druckschwankungen zwischen 0 bis 20 MPa mit Frequenzen zwischen 0,1 bis $10 \mathrm{H}$ (WONG und CARTER 2003; HODGE et al. 1986). Um diesen starken Belastungen standzuhalten, ist das Gewebe sehr komplex konstruiert. Für das Verständnis von Osteoarthrose (OA) ist es daher nötig, den genauen Aufbau und die Biomechanik von gesundem Knorpel zu verstehen.

\subsubsection{Feinstruktur des Gewebes}

Hyaliner Knorpel kann in Matrixregionen bzw. Zonen eingeteilt werden. Man unterscheidet zwischen der perizellulären, der territorialen und der interterritorialen Matrixregion. Jede einzelne Zelle wird dicht von einer dünnen Schicht aus perizellulärer Matrix umgeben. Die perizelluläre Matrix mehrerer Zellen wird zudem schützend von einem dichten Netz aus Kollagen umschlossen, der sogenannten territorialen Matrix. Dazwischen liegen weite Bereiche aus zellfreier, interterritorialer Matrix (BUCKWALTER et al. 2005).

Gelenkknorpel zeigt einen charakteristischen zonalen Aufbau: a) oberflächlich die Tangentialzone mit wenigen, abgeflachten, parallel zur Gelenksfläche angeordneten Zellen, welche zum Gelenkspalt hin durch eine dünne Kollagenfaserschicht (Lamina splendes) abgegrenzt wird, b) die Übergangszone mit zunehmenden runden Zellen, c) die Radiärzone, in der die runden Zellen senkrecht und säulenartig zur Gelenksfläche angeordnet sind und d) die Verkalkungszone mit verkalkter Matrix und wenigen, kleinen und stoffwechselarmen Chondrozyten, welche zur Radiärschicht durch eine basophile Linie abgegrenzt ist (Tidemark). Die Zonen fangen die verschiedenen Kräfte, die auf den Knorpel wirken, nicht gleichmäßig ab. So reguliert die oberflächliche Schicht vor allem Druckkräfte durch Aufnahme und Abgabe von Flüssigkeit, wogegen die widerstandsfähige Radiärschicht vor allem Reiß- und Scherkräften entgegenwirkt. Um diesen Ansprüchen gerecht $\mathrm{zu}$ werden, variiert auch die Zusammensetzung der ECM, die Zellzahl und die Eigenschaften der Zellen zwischen den Zonen (BUCKWALTER et al. 2005; WONG und CARTER 2003; TEMENOFF und MIKOS 2000). 


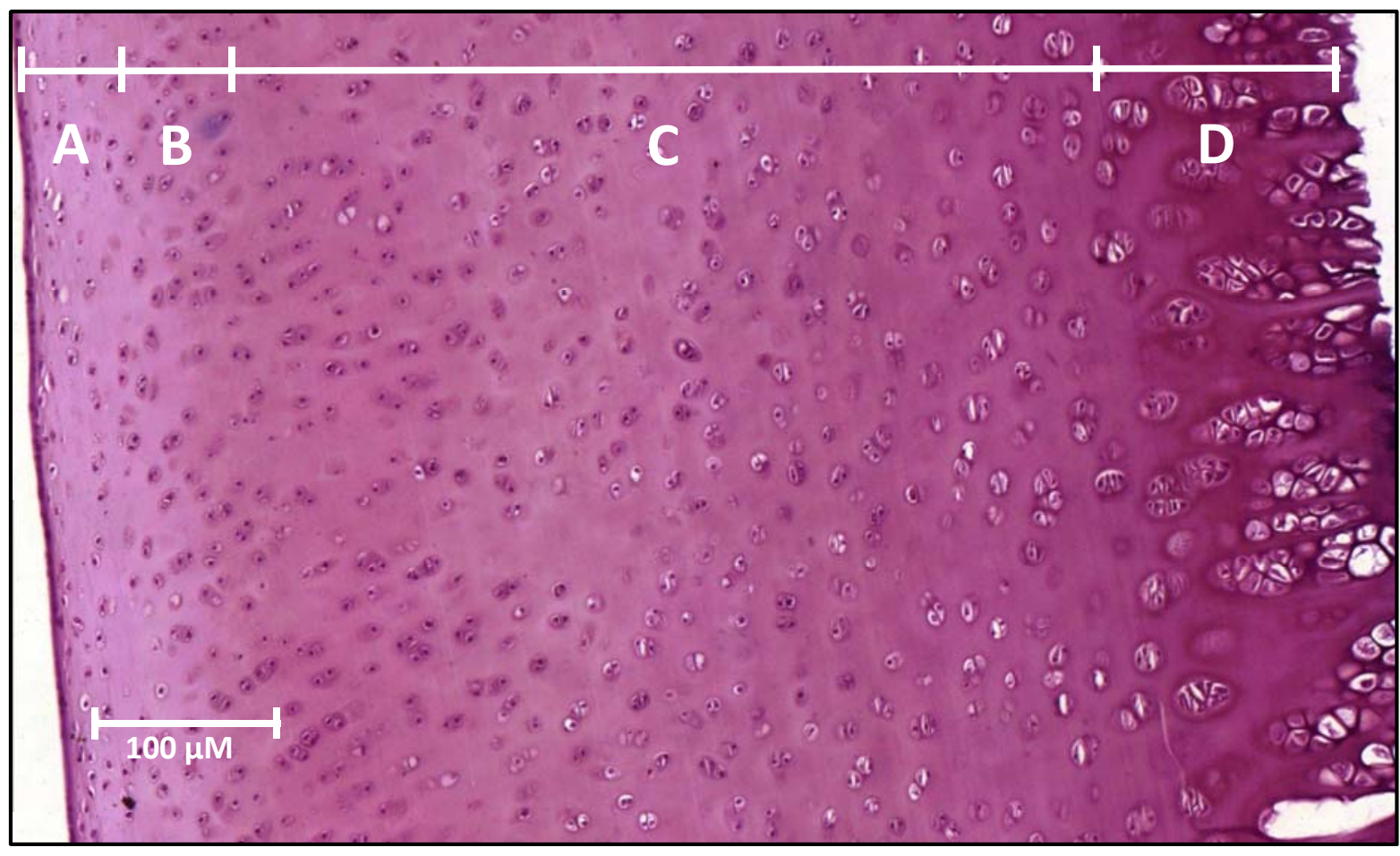

Abbildung 1: Histologischer Schnitt durch porcinen hyalinen Knorpel (Hämatoxylin-EosinFärbung). Anhand der Zellmorphologie und Ausrichtung ist die Gliederung in die verschiedenen Zonen deutlich zu erkennen: Tangentialzone $(A)$, Übergangszone $(B)$, Radiärzone (C) und Verkalkungszone (D). (Bild aus der virtuellen Mikroskopie mit freundlicher Genehmigung von Prof. Dr. Johannes Seeger, Universität Leipzig)

\subsubsection{Bedeutung der Chondrozyten}

Im Gegensatz zu den meisten Geweben im Körper besteht Knorpel nur aus einer Zellart, den Chondrozyten. Adulte, vollständig ausdifferenzierte Chondrozyten sind rund und kaum teilungsfähig. Trotz ihrer geringen Anzahl (1-2\% des Gewebsvolumens) sind diese Zellen für die Bildung und den Erhalt der ECM zuständig. Um diesem Anspruch gerecht zu werden, stehen die Zellen mit der ECM in enger Interaktion und weisen eine Vielzahl an Rezeptoren zur Wahrnehmung von Wachstumsfaktoren, Zytokinen, Matrixbestandteilen sowie von physikalischen Parametern, wie z.B. Druckschwankungen, auf. Sie passen daher ihre Syntheseraten direkt an die Gegebenheiten im Gelenk an und variieren in Größe, Form und metabolischer Aktivität je nach ihrer Beanspruchung und Lage (WONG und CARTER 2003). So sind die metabolisch aktiven Zellen der Radiärzone reich an Zellorganellen wie z.B. Endoplasmatischem Retikulum, Golgi-Apparat und Fettvakuolen (BUCKWALTER et al. 2005; WONG und CARTER 2003; STOCKWELL 1967). Da sie vollständig von ECM umschlossen sind, decken sie ihren Energiebedarf in erster Linie aus anaerober Glykolyse (MURPHY et al. 2009). 


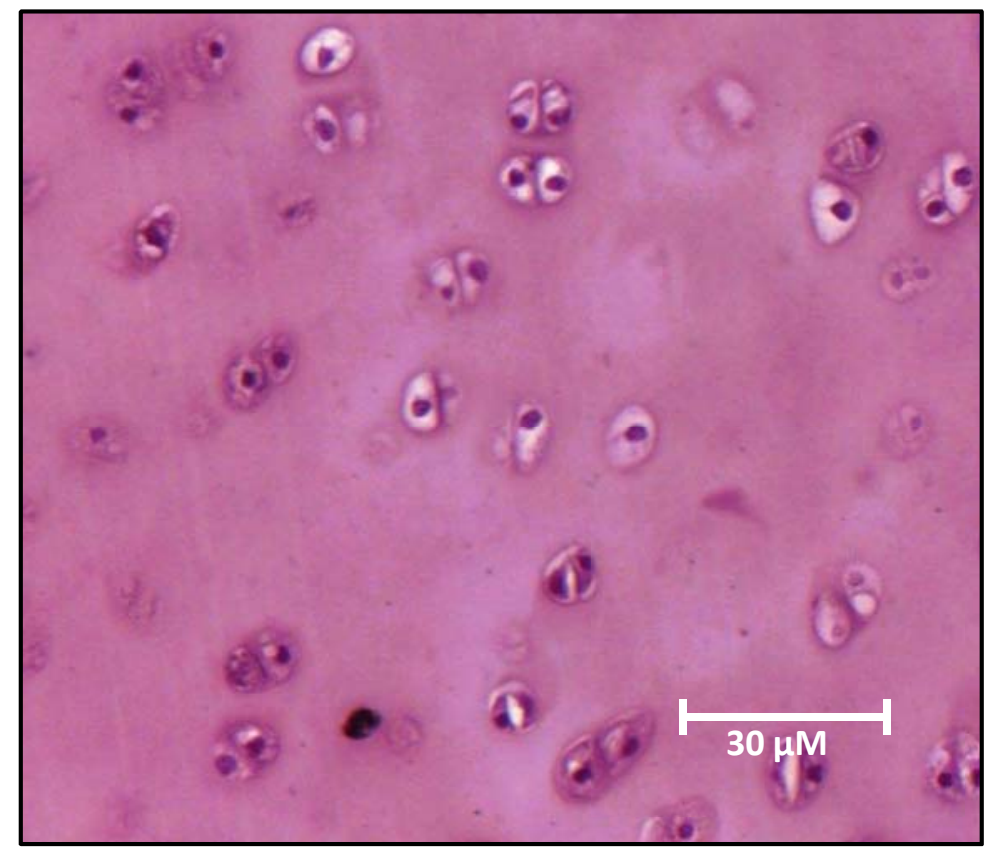

Abbildung 2: Histologischer Schnitt durch porcinen hyalinen Knorpel (Hämatoxylin-EosinFärbung).

Mehrere Chondrozyten liegen als sogenannte Territorien oder Chondrone abgekapselt in der extrazellulären Matrix. (Bild aus der virtuellen Mikroskopie mit freundlicher Genehmigung von Prof. Dr. Johannes Seeger, Universität Leipzig)

\subsubsection{Aufbau der Extrazellulären Matrix (ECM)}

Die Widerstandsfähigkeit und Verformbarkeit des Knorpelgewebes werden durch den charakteristischen Aufbau der ECM bestimmt. Die ECM macht über $98 \%$ der Knorpelmasse aus und besteht zum größten Teil aus Wasser und Makromolekülen, wie z.B. Kollagen und Proteoglykanen sowie wenigen anderen Proteinen. Das mit Abstand häufigste Kollagen ist Kollagen II, welches viele, kreuzförmig verlaufende Fasern aus zopfartig verwundenen Polypeptidsträngen bildet. Kollagen VI, IX, X und XI stabilisieren diese Fasern und dienen der Signalvermittlung zwischen der ECM und den Zellen. Das entstehende Netzwerk bildet das Grundgerüst der ECM, in deren Freiräume ihre zweite Hauptkomponente, die Proteoglykane, eingelagert werden (BUCKWALTER et al. 2005; PFANDER 2005). Man unterscheidet zwei Klassen von Proteoglykanen: Kleine einfache Proteoglykane wie Biglykan und Fibromodulin und große Moleküle aus vielen aggregierten Proteoglykanen wie Aggrecan oder Versican. Das häufigste Proteoglykan im Knorpel ist Aggrecan. Es besteht aus einer zentralen Hyaluronsäurekette mit vielen nichtkovalent gebundenen Aggrecanmolekülen, welche ihrerseits aus einem zentralen Kernprotein mit seitlich angelagerten sulfatierten Glykosaminoglykanen bestehen, meist Keratansulfat und Chondroitinsulfat. Aggrecan spielt eine außergewöhnliche Rolle für die Tragkraft des Gelenks. Das Molekül hat die Tendenz, Wasser zwischen den negativ geladenen Glykosaminoglykanketten einzulagern und dadurch aufzuquellen. Das Kollagennetz wirkt dieser Volumenzunahme entgegen und bewirkt damit die Festigkeit des Gewebes. Bei Kompression des Gewebes entlässt Aggrecan das aufgenommene Wasser und bei Entlastung zieht es das Wasser wieder zurück. Dadurch 
entsteht ein dynamischer Transport von Wasser in die ECM, der Nährstoffe und Gase mit sich führt und Abfallstoffe wieder aus der ECM transportiert. OA geht einher mit der Degeneration des Aggrecans und damit dem Verlust dieser essenziellen Eigenschaft (ROUGHLEY und MORT 2014).

\section{$2.2 \quad$ Osteoarthrose (OA)}

\subsubsection{Pathogenese}

\subsubsection{Kausale Pathogenese}

OA ist eine chronische, progressive Erkrankung, die mit einer irreversiblen Zerstörung des Gelenkknorpels einhergeht und letztendlich zu einem funktionellen Versagen des betroffenen Gelenks führt (JOHNSTON 1997). Nach einer Studie zur Gesundheit Erwachsener in Deutschland leiden 20 \% der Menschen zwischen 18 und 79 Jahren in Deutschland unter OA (FUCHS et al. 2013). Aber auch unsere Haustiere sind betroffen. Bei Pferden ist OA einer der wichtigsten Gründe für Lahmheit (MCILLWRAITH et al. 2012). Durch den hohen emotionalen Stellenwert kleiner Haustiere erlangt die Diagnose und Therapie der OA auch bei Hunden und Katzen zunehmend an Bedeutung (PETTITT und GERMAN 2015; BEALE 2004).

Der OA liegt oft eine multifaktorielle Genese zu Grunde. Man unterscheidet zwischen einer OA ohne erkennbaren Grund, der primären oder idiopathischen OA und der sekundären OA, welche aus einem anderen Grundleiden hervorgeht. Während die sekundäre Form beim Menschen eine eher untergeordnete Rolle spielt, ist sie beim Tier vorherrschend (HENROTIN et al. 2005; JOHNSTON 1997). Die Faktoren, welche zum Ausbruch einer sekundären OA führen, lassen sich vereinfacht auf zwei Ursachen zurückführen: Einer abnormen Zusammensetzung des Knorpels (Alter, genetische Krankheiten) oder einer starken mechanischen Belastung (Traumata, Inkongruenz, Überlastung) (HASEEB und HAQQI 2013; FELSON 2013).

Eine Sonderform stellt die metabolische OA da. So führt Übergewicht neben einer chronischen Überlastung der Gelenke auch zur Produktion einer Vielzahl an systemischen Faktoren wie z.B. Adipokinen, welche die Entzündungsneigung des Körpers erhöhen und damit das Risiko steigern, an OA zu erkranken (WANG et al. 2015). Mit der Entdeckung der metabolischen OA konnte zum ersten Mal bewiesen werden, dass OA mit anderen Organen in Wechselwirkung steht und damit nicht als rein lokale Erkrankung zu sehen ist. Inzwischen wurde gezeigt, dass OA beim Menschen auch die Genexpression der peripheren Blutleukozyten verändert (ATTUR et al. 2011) und auch gelenkferne Krankheiten, wie z.B. Alzheimer auslösen kann (KYRKANIDES et al. 2011). Durch diese Erkenntnisse wird OA seit neuestem als systemische Krankheit definiert (CICUTTINI und WLUKA 2014; MALEMUD 2015). 


\subsubsection{Formale Pathogenese}

Unter physiologischen Umständen herrscht im Knorpel ein dynamisches Gleichgewicht zwischen Synthese und Abbau. Wird dieses Gleichgewicht gestört, kommt es zu einem zyklischen Krankheitsverlauf mit chronisch progressiver Zerstörung des Gelenkknorpels (HOUARD et al. 2013).

Histopathologisch unterscheidet man vier Krankheitsgrade (PFANDER 2005). Zu Beginn sind die Veränderungen marginal und betreffen nur die Matrixzusammensetzung der obersten Gewebsschichten. Der Proteoglykangehalt sinkt und die Glykosaminoglykanketten nehmen an Länge ab. Durch diese Veränderungen wird vermehrt Wasser in die ECM eingelagert (Grad I). Als Nächstes kommt es zu einer Umgestaltung der Querverbindung zwischen den Kollagenfasern und damit zu einer Linearisierung und Auflockerung des Kollagenfasernetzes (Grad II). Zusammen führen beide Veränderungen zu einer Erweichung der ECM mit oberflächlicher Faserzeichnung („Asbestzeichnung“). Die Widerstandsfähigkeit des Gewebes gegenüber Scherkräften nimmt ab und führt zu oberflächlichen Fissuren in beanspruchten Arealen. Mit der Zeit setzen sich die Matrixveränderungen von den oberflächlichen Schichten bis zur Übergangs- und Radiärschicht fort. Die Zellen registrieren die Veränderungen und versuchen, die entstehenden Defekte durch einen gesteigerten Umbau der ECM auszugleichen. Dieser Umbau geht einher mit der Produktion von anabolen Faktoren, wie Wachstumsfaktoren und Matrixproteinen, und katabolen Faktoren, wie Proteinasen und Entzündungsmediatoren. Die bisher amitotischen Zellen reaktivieren ihre Teilungsfähigkeit und bilden Chondrozytennester, die aus bis zu 20 hypertrophen Zellen bestehen. Bei kleinen Defekten kann der intrinsische Reparaturversuch durchaus zu einer Ausheilung führen, jedoch reicht die Syntheseleistung der Zellen bei größeren Defekten nicht aus. In der Umgebung des Defektes kommt es zu einer fortschreitenden Dysbalance zwischen Matrixabbau und Matrixaufbau. Syntheseaktive Zellen gehen durch Apoptose verloren. Um die Stabilität zu erhöhen, lagert das Gewebe zunehmend Kalziumpyrophosphatdihydrat ein und erschwert dadurch zunehmend die Versorgung der verbliebenen Zellen (Grad III). In der finalen Phase versagt schließlich die Funktionalität des Gewebes und der Knorpel ulzeriert bis auf den subchondralen Knochen (Grad IV) (TALLHEDEN et al. 2006; BUCKWALTER et al. 2005; PFANDER 2005).

Die zugrundeliegende biochemische Pathogenese der OA gilt als äußerst komplex und konnte bis heute nicht vollständig geklärt werden (XIA et al. 2014). Es handelt sich insgesamt um ein komplexes Zusammenspiel von verschiedenen katabolen und anabolen Faktoren, die gemeinsam zu einer Schädigung der beteiligen Strukturen führen. Dementsprechend gestaltet es sich schwierig, einen initialen Auslöser der Krankheit zu definieren. Es ist aber allgemein bekannt, dass eine Ausschüttung pro-inflammatorischer Zytokine, Wachstumsfaktoren und 
Chemokine wie Interleukin-1 $\beta$ (IL-1 $\beta$ ), Interleukin-6, Tumor Nekrose Faktor- $\alpha$ (TNF- $\alpha$ ) und Transforming Growth Faktor- $\beta$ (TGF- $\beta$ ) den ersten histopathologischen Veränderungen vorangeht. Diese Mediatoren sowie abnorme mechanische Reize sprechen eine Vielzahl von Rezeptoren auf den Chondrozyten an und aktivieren damit verschiedene Signalwege, welche ihrerseits die Transkription nachgeschalteter Zielgene auslösen. Dazu gehören unter anderem matrixabbauende Proteasen, Gene, die an der Produktion von Entzündungsmediatoren beteiligt sind und Gene, die eine Apoptose der Chondrozyten bewirken (WOJDASIEWICZ et al. 2014). Neue Untersuchungen zeigen außerdem eine Beteiligung von reaktiven Sauerstoffspezies (ROS), Adipokinen, einem gestörten Immunsystem, Vitamin D und dysregulierten mikro-Ribonukleinsäuren (miRNAs) (MALEMUD 2015).

Neben dem Knorpelgewebe sind andere Gewebe des Gelenks maßgeblich an der Pathogenese beteiligt.

Obgleich OA zu den degenerativen Erkrankungen gezählt wird, ist eine nicht-klassische Entzündung des Gelenks ein wesentlicher Aspekt der Krankheit (MALEMUD 2015). Eine zentrale Rolle spielt dabei die den Gelenkspalt umgebende Synovialis und ihre Interaktion mit dem angeborenen und adaptiven Immunsystem. Freigesetzte Fragmente der ECM reagieren als Autoantigene (DAMPs=damage-associated molecular patterns oder Alarmine) und aktivieren über Pattern Recognition Rezeptoren (z.B. Toll-like Rezeptoren) Synovialozyten und verschiedene Zellen des Immunsystem wie Makrophagen, T- und B-Zellen. Diese Zellen schädigen das Gewebe nicht nur durch eine zusätzliche Bildung von Entzündungsmediatoren und Proteasen, sondern darüber hinaus durch eine Aktivierung des Komplementsystems und die Bildung von Autoantikörpern. Die Beteiligung des Immunsystems manifestiert sich in Form einer milden bis moderaten Synovitis. Neben einer Beteiligung am progressiven Verlauf wird der Synovialis inzwischen auch eine Rolle als ein möglicher Initiator der Krankheit zugeschrieben (BERENBAUM 2013; HASEEB und HAQQI 2013).

Der subchondrale Knochen ist der zweite Teil des Gelenks, der wesentlich zum Fortschreiten der Krankheit beiträgt (MALEMUD 2015). Auch hier werden massiv Entzündungsmediatoren durch eingewanderte Osteoklasten und Osteoblasten gebildet, welche von dort in den Knorpel diffundieren (BERENBAUM 2013; HOUARD et al. 2013). Zusätzlich bestimmt der subchondrale Knochen die mechanische Pathogenese der OA (FELSON 2013). Durch den abnehmenden Schutz der Knorpelschicht ist der Knochen erhöhten Belastungen ausgesetzt. Er entwickelt eine reaktive Sklerose mit vereinzelten Zysten, Mikrofrakturen und Fissuren (BUCKWALTER et al. 2005). Im Randbezirk des Gelenks erfolgt die Bildung von Osteophyten (PFANDER 2005). Diese Umbauvorgänge verstärken die Inkongruenz und damit die Fehlbelastung der Gelenksflächen und potenzieren die degenerativen Vorgänge im Knorpel 
(FELSON 2013). Ausgehend vom Knochen kommt es außerdem bei tiefen Defekten zu einer vorübergehenden Reparatur des Knorpelgewebes. Wird eine Blutung des subchondralen Knochens ausgelöst, organisieren Knochenmarksstammzellen das Blutgerinnsel zu einem faserknorpelähnlichen Ersatzgewebe. Dieses Narbengewebe ist dem eigentlichen Gelenkknorpel biomechanisch unterlegen und geht auf Grund entzündlicher Vorgänge und Belastungen mit der Zeit ebenfalls verloren (HUNZIKER 2002; TEMENOFF und MIKOS 2000).

\subsubsection{Die Rolle der Zytokine}

\subsubsection{Interleukin-1 $\beta$ (IL-1 $\beta)$}

Pro-inflammatorische Zytokine spielen als Hauptursache der Entzündungsprozesse eine zentrale Rolle in der Pathogenese der OA. Besonders prominent ist dabei das Zytokin IL-1 $\beta$, welches neben TNF- $\alpha$ lange Zeit als wichtigster Verursacher des gestörten Knorpelmetabolismus angesehen wurde (MALEMUD 2015; HASEEB und HAQQI 2013; FERNANDES et al. 2002). Inzwischen gibt es jedoch auch Untersuchungen, welche die Schlüsselrolle von IL-1 $\beta$ als Initiator der OA in Frage stellen (SANDY et al. 2015; RICHETTE et al. 2008) und inm eine größere Bedeutung in der Pathogenese der rheumatoiden Arthritis zusprechen (KOKEBIE et al. 2011).

Das Zytokin IL-1 $\beta$ ist eines von 11 Mitgliedern der Interleukin-Familie und wird mittels limitierter Proteolyse durch Caspase-1 (ICE; interleukin-1 converting enzyme) aus einem zytosolischen Vorläuferprotein aktiviert. Im gesunden Gelenk liegt es im Gleichgewicht mit seinem kompetitiven Gegenspieler Interleukin-1 Rezeptor Antagonist (IL-1Ra) vor (WOJDASIEWICZ et al. 2014; DAHESHIA und YAO 2008a). Im Zuge der OA wird IL-1 $\beta$ von verschiedenen Zellen des Gelenks unter anderem Synovialozyten (SMITH et al. 1997) und Osteoblasten (MASSICOTTE et al. 2002) überexprimiert und kann daher in erhöhten Mengen im Knorpel und in der Synovia nachgewiesen werden (TSUCHIDA et al. 2014; SOHN et al. 2012). Zeitgleich kommt es zum Anstieg der IL-Rezeptoren I und II (IL-1R I und IL-1R II) (SHLOPOV et al. 2000) sowie zum Abfall des Antagonisten IL-1Ra (SMITH et al. 1997). Die Prozesse erleichtern die Bindung von IL-1 $\beta$ an den Rezeptor und lösen so eine komplexe Signalkaskade aus, welche die Transkriptionsfaktoren NF-KB (nuclear factor "kappa-light-chain-enhancer" of activated B-cells), p38 MAPK (p38-mitogenaktivierte Proteinkinasen) und JNK (c-Jun Nterminale Kinasen) aktivieren. Die Transkriptionsfaktoren bewirken eine Veränderung der Genexpression, welche eine Verstärkung der katabolen Stoffwechselwege bei gleichzeitiger Schwächung der anabolen Stoffwechselwege zur Folge hat. So führt IL-1 $\beta$ zu einem Anstieg von Matrixmetalloproteinasen (MMPs, u.a. MMP-1, MMP-3, MMP-13) und Aggrecanasen (ADAMTS, u.a. ADAMTS-4 und ADAMTS-5), vermittelt die Apoptose über freie Radikale (u.a. Stickstoffmonoxid) sowie über pro-apoptotische Proteine (WOJDASIEWICZ et al. 2014; 
DAHESHIA und YAO 2008b; FERNANDES et al. 2002) und verhindert durch eine Hemmung der Transkription von Kollagen II und Aggrecan eine Reparatur der entstandenen Defekte (PUJOL et al. 2008; PFANDER et al. 2004). Die destruktive Wirkung wird noch potenziert durch die Interleukin-vermittelte Einwanderung von Entzündungszellen in das Gelenk. (DAHESHIA und YAO 2008b). Auf autokrinem Wege steigert IL-1 $\beta$ außerdem die Bildung anderer Zytokine und die eigene Produktion (AIGNER et al. 2006).

\subsubsection{2}

Transforming Growth Factor- $\beta$ (TGF- $\beta$ )

Die Transforming Growth Factor Superfamilie besteht aus über 30 Liganden, welche mit Hilfe von Smad-Proteinen in den Zellstoffwechsel von verschiedenen Geweben eingreifen. Im Knorpel werden ihnen im Gegensatz zu IL-1 $1 \beta$ eine rege Beteiligung an den anabolen und antikatabolen Prozessen zugeschrieben (ZHAl et al. 2015).

TGF- $\beta 1,-\beta 2$ und $-\beta 3$ und ihre Rezeptoren sind im gesunden Knorpel in größeren Mengen in den oberflächlichen und unreifen Knorpelschichten vorzufinden (BAUGÉ et al. 2014). Nach der Synthese und der Prozessierung im Golgi-Apparat werden die Vertreter der TGF- $\beta$ Familie an Proteine gebunden und entweder als kleiner dimerer Komplex von den Zellen sekretiert („small latent complex“) oder als großer Komplex in die ECM eingebaut (,large latent complex"). Eine Abspaltung der Proteine durch Enzyme oder pH-Veränderungen legt die aktiven Liganden frei, welche an den TGF- $\beta$ Typ II Rezeptor binden und schließlich an der Zelloberfläche mit dem TGF- $\beta$ Typ I Rezeptor zu einem großen Rezeptorkomplex fusionieren. Der Rezeptorkomplex setzt eine Kaskade aus Smad-Proteinen in Gang, beginnend mit der Phosphorylierung von R-Smads (Rezeptor-regulierte Smads z.B. Smad-2/-3), die sich anschließend mit dem Co-Smad (Common-Partner Smad, Smad-4) vereinigen und gemeinsam als Transkriptionsfaktoren die Genexpression ausgewählter Zielgene beeinflussen. Dieser kanonische Smad-Weg kann von den Gegenspielern der R-Smads, den I-Smads (inhibitorische Smads, Smad-6 und-7) unterbrochen werden. Der alternative nicht-kanonische Weg führt über TGF- $\beta$ aktivierende Kinasen $z u$ anderen Signaltransduktionswegen und beeinflusst so ebenfalls den Knorpelstoffwechsel. (BAUGÉ et al. 2014; ZHAl et al. 2015). Im Alter kommt es beim Menschen zu einer Verschiebung der Wege von R-Smad-2/-3 zu R-Smad-1/-5/-8 und zu einer geringeren Expression von TGF- $\beta$ Rezeptoren. Diese Veränderung der Transduktionswege führt zu einer geringeren protektiven Wirkung von TGF- $\beta$ und bietet wahrscheinlich die Erklärung für die altersbedingte OA beim Menschen (BAUGÉ et al. 2014; VAN DER KRAAN 2014; BLANEY DAVIDSON et al. 2005). Es ist bekannt, dass TGF- $\beta$ eine Schlüsselrolle in der Chondrogenese spielt (TANG et al. 2009) und es findet daher verbreitete Anwendung in der Stammzellforschung in chondrogenen Differenzierungsmedien (CSAKI et al. 2007). Es trägt wesentlich zum Erhalt des 
Knorpelgewebes bei, indem es die Bildung von Proteoglykanen und Kollagen II fördert (BURTON-WURSTER et al. 2003; HUNZIKER 2002; DEMOOR-FOSSARD et al. 1999), deren Abbau vermindert (TCHETINA et al. 2006) und die Apoptose der Chondrozyten hemmt (LIRES-DEAN et al. 2008). TGF- $\beta$ ist zusätzlich ein wichtiger Regulator des Knochenstoffwechsels und beeinflusst die Aktivität von Osteoblasten und Osteoklasten (MOULHARAT et al. 2004). Aufgrund dieser Eigenschaften rückt TGF- $\beta$ in den Fokus der Forschung als neuer Therapieansatz zur Behandlung der OA.

Neben einigen vielversprechenden Ergebnissen wurden jedoch vor allem bei hohen Dosen und langer Anwendungsdauer schädliche Wirkungen nachgewiesen, welche die vorteilhafte Rolle der TGF- $\beta$ Familie bei degenerativen Gelenkserkrankungen in Frage stellen. Die intraartikuläre Applikation von TGF- $\beta$ in Tiermodellen führte zu einer hohen Komplikationsrate mit Bildung von Pannus, Osteophyten, Schwellung und Gelenksergüssen (HUNZIKER 2002; ELFORD et al. 1992). Darüber hinaus steuert TGF- $\beta$ über miRNAs die selektive Degeneration der ECM durch proteolytische Enzyme wie ADAMTS-5 und MMP-13 (AREF-ESHGHI et al. 2015; ZHAl et al. 2015; MOULHARAT et al. 2004) und ist beteiligt an dem nicht-entzündlichen Gelenksschmerz (BLANEY DAVIDSON et al. 2015). In Mausmodellen konnte bewiesen werden, dass eine Hemmung von TGF- $\beta$ Rezeptor II vor der Ausbildung einer OA schützt (CHEN et al. 2015; SCHARSTUHL et al. 2002). Die Erklärung für die ambivalenten Wirkungen liegt wahrscheinlich ebenfalls in einer Verschiebung der Smad-Wege zu Smad-1/-5/-8 (ZHAO et al. 2016).

Wie in vitro gezeigt werden konnte, stehen TGF- $\beta$ und IL-1 $\beta$ in enger Interaktion. Bei gleichzeitiger Gabe von TGF- $\beta$ und IL-1 $\beta$ kommt es bei Kaninchen-Chondrozyten zu einer verminderten Expression des IL-Rezeptors und damit zu einer geringeren Bindung von IL-1 $\beta$ (PRONOST et al. 1995; RÉDINI et al. 1993; HARVEY et al. 1991). Im Gegenzug unterdrückt IL-1 $\beta$ die Signaltransduktion von TGF- $\beta$ durch eine Reduktion des TGF- $\beta$ Typ II Rezeptors zusammen mit einer Steigerung von I-Smad-7 (BAUGÉ et al. 2007). In einem Teil der Studien konnte gezeigt werden, dass TGF- $\beta$ einige schädliche Effekte von IL-1 $\beta$ antagonisieren kann, unter anderem die Matrixdegeneration durch Matrixproteinasen (HARVEY et al. 1991) sowie die Bildung von Stickstoffmonoxid (NO) (VUOLTEENAHO et al. 2005; BLANCO et al. 1995). Andere Untersuchungen führen jedoch zu keinem eindeutigen Ergebnis in Bezug auf die Wirkung von TGF- $\beta$ bei einer simultanen Inkubation mit IL-1 $\beta$ (FAWTHROP et al. 1997; MEJIERS et al. 1994; PUJOL et al. 1991). 


\subsubsection{Rolle der Matrixproteinasen MMP und ADAMTS}

Die irreversible Zerstörung der Knorpelmatrix gilt als Schlüsselereignis der OA und involviert eine Vielzahl von proteolytischen Enzymen. Zwei Enzymfamilien stechen dabei besonders hervor: Die Familie der „A Disintegrin and Metalloproteinase with Thrombospondin Motifs“ (ADAMTS) und die Familie der Matrixmetalloproteinasen (MMP). Es handelt sich bei beiden Familien um Zink-abhängige Proteinasen, welche zuerst als inaktive Zymogene ausgeschüttet werden und anschließend durch andere Proteasen oder äußere Faktoren wie pH-Abfall oder Hitze aktiviert werden (CUI et al. 2017; NAGASE und KASHIWAGI 2003; CAWSTON 1998). Sie unterliegen im Gelenk einer komplexen Regulation mit Angriffspunkten auf multiplen Ebenen, unter anderem durch verschiedene Transkriptionsfaktoren, miRNAs (LI et al. 2017) und Interaktion mit ihren natürlichen Hemmstoffen, den Tissue Inhibitors of Metalloproteinases (TIMP) (MURPHY und LEE 2005).

Die Familie der ADAMTS (19 Mitglieder) wurde erst vor kurzem entdeckt. Sie binden mit ihrem Typ-1 Thrombospondin an die sulfatierten Glykosaminoglykane und hydrolysieren die Bindung zwischen Glutaminsäure 373-Alanin 374 in der interglobulären Domäne vom Aggrecan-Kernprotein (SANDY et al. 1992). Zurück bleiben verkürzte Aggrecanketten mit einer geringen Wasserbindungskapazität, welche die Belastbarkeit der ECM gegen Druckkräfte herabsetzen und damit die Funktionalität des Aggrecans zerstören (ROUGHLEY und MORT 2014). Durch den Abbau des Aggrecans wird das darunterliegende Kollagennetz freigelegt und damit angreifbar für die MMPs (NAGASE und KASHIWAGI 2003).

Die Familie der MMPs enthält 28 Mitglieder mit einem typischen Aufbau, bestehend aus einem Propeptid aus 80 Aminosäuren, einer katalytischen Domäne mit zwei gebundenen Zink-lonen, einem Verknüpfungspeptid und einer Hämopexin-Domäne (CUl et al. 2017). Die MMPs können je nach Domänenorganisation in vier Subtypen eingeteilt werden: (1) Gelatinasen, (2) Matrilysine, (3) Archetypale MMPs inklusive Stromelysine und Kollagenasen, und (4) Furinaktivierbare MMPs (LI et al. 2017). Neben ihrer Beteiligung an pathologischen Vorgängen haben sie einen Einfluss auf physiologische Abläufe wie Proliferation, Differenzierung und Angiogenese. So spalten sie Chemokine, Zytokine und deren Rezeptoren und regulieren so Zell-Zell und Zell-Matrix Interaktionen (CUI et al. 2017; MOHAMMED et al. 2003). In der OA spielen vor allem die kollagenolytischen MMPs eine große Rolle, welche die Tripelhelix des Kollagens spalten (Glycin 775-Leucin 776) und damit dem Knorpelgewebe die Stabilität und Widerstandsfähigkeit gegen Scherkräfte nehmen (CUI et al. 2017; POOLE et al. 2003). Zudem sind MMP-1, -3, und-13 in der Lage, das Aggrecan zu spalten (LITTLE et al. 2002). Durch beide Enzymfamilien gemeinsam kommt es zum endgültigen Versagen der Funktionalität der ECM und damit zu großflächigen Erosionen. Darüber hinaus binden Bruchstücke von 
Fibronektin und Kollagen II an nicht-katalytischen Domänen und steigern so die Aktivität der MMPs auf autodegenerativem Weg (POOLE et al. 2003).

Die Protease mit der größten Bedeutung für den Untergang der ECM ist Kollagenase-3 oder MMP-13 (LI et al. 2017; VAN DEN BERG 2011). Dabei handelt es sich um das Enzym mit der höchsten Umsatzrate für Kollagen II (XIA et al. 2014). Schon in den frühen Krankheitsstadien wird es stark überexprimiert (SATO et al. 2006). Wie an MMP-13 Knockout-Mäusen bewiesen werden konnte, spielt es im Krankheitsverlauf der OA eine Schlüsselrolle (LITTLE et al. 2009).

MMP-3 oder Stromelysin-1 zersetzt eine Vielzahl von Matrixbestandteilen, im Gegensatz zu MMP-13 wird ihm beim Hund jedoch eine eher untergeordnete Rolle im Kollagenabbau zugeschrieben. Stattdessen hat es eine große Bedeutung für das Ausmaß der Entzündung (HEGEMANN et al. 2002) und aktiviert die proinflammatorischen Zytokine IL-1 $\beta$ und TNF- $\alpha$ (CUI et al. 2017). Durch seine Fähigkeit, die Proenzyme anderer MMPs (u.a. MMP-1 und MMP-8) zu aktivieren, nimmt es außerdem eine Sonderrolle in der kaskadenartigen Freisetzung von matrixdegenerierenden Enzymen ein (CHEN et al. 2014).

Die wichtigste Aggrecanase ist ADAMTS-5 (GLASSON et al. 2005). Niedrige Mengen von ADAMTS- 5 sind jedoch für einen gesunden Knorpelmetabolismus nötig. Erst in hohen Mengen entfaltet das Enzym seine pathologische Wirkung (XIA et al. 2014).

Die Wirkung der MMPs wird unter physiologischen Bedingungen von ihren natürlichen Gegenspielern, den TIMPs, kontrolliert. Über eine riffartige Struktur am N-Terminus dieser Hemmstoffe kommt es zu einer nicht-kovalenten Bindung mit dem aktiven Zentrum der MMPs und damit zu einer Unterbrechung der katalytischen Aktivität. Die insgesamt vier Vertreter der TIMPs hemmen über diesen Mechanismus alle aktiven MMPs sowie vereinzelt deren inaktive Proenzyme und darüber hinaus auch ausgewählte Vertreter der ADAMTS (MURPHY und LEE 2005). Sie werden von verschiedenen Zellen des Gelenks, unter anderem Chondrozyten und Synovialozyten, an die Umgebung abgegeben (CLEMENTS et al. 2009; CLEMENTS et al. 2006; SU et al. 1999). Eine Ausnahme stellt TIMP-3 da, welches als einziger Vertreter der TIMP gebunden an Chondroitinsulfat und Heparansulfat in der ECM vorliegt (YU et al. 2000). Es gibt bisher wenig Untersuchungen zu ihrer Regulation. Jedoch gibt es Anhaltspunkte, dass nicht alle TIMPs induzierbar sind, sondern speziesabhängig konstitutiven Expressionsmustern folgen (BEE et al. 2000). Bei degenerativen Gelenkserkrankungen verschiebt sich das Gleichgewicht zwischen TIMPs und MMPs zugunsten der MMPs und erhöht somit die Wirksamkeit der freigesetzten Proteinasen als matrixschädigende Enzyme. Daher gilt das TIMP/MMP Verhältnis als Maß für eine fortschreitende Knorpeldegeneration (CUI et al. 2017; BEE et al. 2000). 


\subsubsection{Rolle der Entzündungsmediatoren}

\subsubsection{Stickstoffmonoxid (NO)}

Stickstoffmonoxid (NO) ist ein labiles, gasförmiges Radikal, welches in Gegenwart von Sauerstoff schnell zu Nitrat oder Nitrit umgewandelt wird. Es entsteht bei der Oxidation von L-Arginin zu L-Citrullin durch die Isoformen der Stickstoffmonoxidsynthase (NOS) (PALMER et al. 1988). Man unterscheidet zwischen den beiden konstitutiv exprimierten NOS, der neuronalen (nNOS) und der endothelialen Form (eNOS), sowie der induzierbaren NOS (iNOS). Chondrozyten exprimieren nur die eNOS und die iNOS (HENROTIN et al. 2003).

NO zählt beim Menschen als Biomarker zur Früherkennung degenerativer Gelenkserkrankungen (PANINA et al. 2017). Bei OA spielt vor allem die vermehrte Bildung von NO durch die iNOS eine wichtige Rolle, wogegen die eNOS keine wesentliche Rolle im Krankheitsverlauf einnimmt. Die iNOS kann sowohl von mechanischen (GUPTA et al. 2008; LEE et al. 2003) als auch biochemischen Faktoren, wie zum Beispiel IL-1 $\beta$ und TNF- $\alpha$, induziert werden (VUOLTEENAHO et al. 2005; BLANCO und Lotz 1995) und führt zu einer überschießenden Produktion von NO durch Chondrozyten (MELCHIORRI et al. 1998) und Synovialozyten (OSTOJIC et al. 2017).

Das gebildete NO erfüllt im Körper eine ambivalente Funktion. In physiologischen, konstitutiven Mengen und in einem ausgewogenen Redoxmilieu hat NO eine wichtige Rolle als Botenstoff. Unter pathologischen Bedingungen hingegen kommt es zur Reaktion von NO mit Superoxidanionen und damit zur Bildung des weitaus schädlicheren Peroxinitrit (HENROTIN et al. 2003). Bei OA können eine Vielzahl der katabolen Wirkungen von NO auf ein erhöhtes Level von Sauerstoffradikalen und dem daraus resultierenden Peroxinitrit zurückgeführt werden. Zu diesen Wirkungen zählen eine verlangsamte Reparatur bestehender Knorpeldefekte durch eine Hemmung der Proteoglykan- (OH et al. 1998; TASKIRAN et al. 1994) und Kollagen II-Synthese (CAO et al. 1997) sowie eine verminderte Ansprechbarkeit auf Wachstumsfaktoren wie Insulin-like Growth Faktor 1 (STUDER et al. 2000). Darüber hinaus führt NO zu einer erhöhten Aktivität von MMPs (MURRELL et al. 1995) und zur Apoptose der Knorpelzellen (YASUHARA et al. 2005; WHITEMAN et al. 2004; PELLETIER et al. 2000) und damit zu Knorpelgewebsverlusten. Der Metabolismus von NO und Prostaglandin E2 (PGE2) ist eng verknüpft (ABRAMSON 2008; BLANCO und LOTZ 1995). So führt eine Bildung von Peroxinitrit zu einer Reduktion der Cyclooxygenase-2 (COX-2) und damit einhergehend zu einer verminderten Ausschüttung von PGE2 (MATHY-HARTERT et al. 2003). 


\subsubsection{Prostaglandin E2 (PGE2)}

Bei OA kann im Knorpel ein breites Spektrum an Eicosanoiden und Lipoxiden nachgewiesen werden, unter anderem PGE2, PGF2 $\alpha$, PGF1 $\alpha$, Thromboxan B2, PGD2 und Leukotrien B4 (ATTUR et al. 2012).

Eine Schlüsselrolle spielt dabei das Eicosanoid PGE2. Es gehört zu der 2er-Serie der PG und damit zu den PG, die im Körper am häufigsten vorkommen (SMITH et al. 2011). Ausgangssubstanz für PGE2 ist die mehrfach ungesättigte Fettsäure Arachidonsäure (AA), welche aus den Phospholipiden der Zellmembran mittels der zytosolischen oder sekretorischen Phospholipase A2 (cPLA2 und sPLA2) freigesetzt wird (ATTUR et al. 2012). Unter Einfluss der Cyclooxygenasen (COX; Synonym: Prostaglandin Endoperoxide Synthasen) wird AA zu PGH2, dem Vorläufermolekül aller PG umgesetzt. Es existieren zwei Formen der COX: eine konstitutive COX-1, die an regulativen physiologischen Vorgängen beteiligt ist, und eine induzierbare COX-2, die präferentiell bei pathologischen Zuständen gebildet wird (SMITH et al. 2011). Das entstehende PGH2 wird anschließend mittels der PGE Synthase zu PGE2 umgewandelt (KOROTKOVA und JAKOBSSON 2014). Bei Entzündungsprozessen kommt es, ausgelöst durch verschiedene Faktoren, unter anderem IL-1 $\beta$ (SHIMPO et al. 2009), mechanische Reize (WANG et al. 2013a) und Adipokine (GOSSET et al. 2008), zu einer verstärkten Nutzung der COX-2 und PGE Synthase und damit zu einer überschießenden Ausschüttung von PGE2.

PGE2 vermittelt seine Wirkung über vier G-Protein gekoppelte Rezeptoren (EP1-EP4), die verschiedene Affinitäten zu PGE2 aufweisen und mit verschiedenen Transduktionswegen verknüpft sind. Je nachdem welcher Rezeptor im Gewebe dominiert, kommt es zu verschiedenen und teilweise ambivalenten Wirkungen (ATTUR et al. 2008; TCHETINA et al. 2007). So hat PGE2 in niedrigen Dosen (bis $70 \mathrm{pg} / \mathrm{ml}$ ) eine eher matrixfördernde Wirkung (TCHETINA et al. 2007). Es hemmt die IL-induzierte Bildung von MMPs (NISHITANI et al. 2010), stimuliert die Kollagen- und Proteoglykansynthese (O'KEEFE et al. 1992) und reguliert die Zellreifung der Chondrozyten (CLARK et al. 2009). In hohen Dosen hingegen bedingt PGE2 typische Entzündungssymptome, forciert die IL-induzierte Ausschüttung von MMP-13 und ADAMTS-5 und hemmt die Proteoglykansynthese (ATTUR et al. 2008). Darüber hinaus vermittelt PGE2 in hohen Konzentrationen die Knorpelzellapoptose und führt zur Ausschüttung anderer Entzündungsmediatoren wie NO (LI et al. 2009). Zusätzlich spielt PGE2 eine Schlüsselrolle bei der Ausbildung von Arthroseschmerz und der Schmerzweiterleitung im Rückenmark (LEE et al. 2013). 
Die Pathogenese der OA gilt als äußerst komplex und konnte bis heute nicht vollständig geklärt werden (XIA et al. 2014). Dementsprechend schwierig gestaltet es sich, ein adäquates Modellsystem zu finden. Neben zahlreichen in vivo Modellen (AMEYE und YOUNG 2006), finden vor allem in vitro Modelle auf Basis einer Chondrozytenkultur Verwendung. Die Chondrozyten werden in Form von Explantkulturen, 2D-Monolayerkultur oder eingebettet in Matrixersatz als 3D-Kultur genutzt (JOHNSON et al. 2016). In 2D-Kulturen werden die isolierten Zellen über lange Zeiträume als Monolayer kultiviert und passagiert, um genügend Zellen zu bekommen. Ein unerwünschter Nebeneffekt ist dabei die fortschreitende Entdifferentzierung der Kultur. Entdifferentzierung ist definiert als der Verlust des Chondrozytenphänotyps und wird charakterisiert durch eine erhöhte Expression von Kollagen-I bei gleichzeitigem Rückgang der Expression typischer Chondrozytenmarker wie Kollagen-II. Die Morphologie der Zellen verändert sich von einer polymorphen, runden Form zu einer abgeflachten, fibroblastoiden Gestalt (MINEGISHI et al. 2013; CARON et al. 2012). Der Prozess der Entdifferentzierung beginnt, sobald die Zellen aus ihrer natürlichen ECM gelöst werden und ist erst nach circa fünf Passagen abgeschlossen (KANG et al. 2007; BENYA et al. 1978).

Die einfachste Kulturform, die Explantkultur (CURTIS et al. 2002b; LEVIN et al. 2001), verlangsamt den Prozess der Entdifferentzierung, indem sie die Zellen in ihrer natürlichen ECM belässt. Eine Einbettung der Zellen in 3D-Medien wie Alginat (RAI et al. 2009; LEMARE et al. 1998), Agarose (KENNETH et al. 2010) oder synthetische Polymergele (KAPS et al. 2004) sowie die erhöhte Zelldichte in einer Pelletkultur (ZHANG et al. 2004) fördern eine Redifferentzierung der Zellen. Darüber hinaus lässt sich die Matrixproduktion durch Medienzusätze wie Ascorbinsäure oder Insulin fördern (CIGAN et al. 2013; PRIDDY II et al. 2001).

Bei der Induktion der OA unterscheidet man im Wesentlichen zwei Modellsysteme: Zytokinbasierte Modelle und Belastungs-basierte Modelle (JOHNSON et al. 2016). In vitro wird OA durch hohe Level an katabolen Zytokinen initiiert. Dementsprechend eignen sich IL-1 $\beta$ und TNF- $\alpha$ exzellent als Trigger für ein in vitro Modell und führen oft zu Entzündungsmustern, die der natürlichen OA weitgehend entsprechen (RAI et al. 2008; KUROKI et al. 2005; COOK et al. 2000). Belastungs-basierte Modelle stützen sich auf die These, dass OA zu einem großen Teil durch eine abnorme Belastung der Gelenke vorangetrieben wird. So führen Zug und Druckbelastungen in 3D-Chondrozytenkulturen zu Zellsterben und einem Anstieg an katabolen Enzymen (FITZGERALD et al. 2004; LEVIN et al. 2001).

Da der Ablauf der caninen OA dem Ablauf der humanen $O A$ ähnelt und Hunde-Chondrozyten leichter zu beschaffen sind, gewinnen canine Chondrozyten zunehmend an Bedeutung als 
Material für Modellsysteme (FRYE et al. 2016; KUROKI et al. 2010; RAI et al. 2008). Solche Studien involvieren canine 2D- und 3D-Systeme und induzieren die Krankheit mit Hilfe von IL-1 $\beta$, IL-1 $\alpha$, TNF- $\alpha$ oder einer Kombination aus mehreren Zytokinen (DYCUS et al. 2013; RAI et al. 2008; KUROKI et al. 2005; COOK et al. 2000) oder seltener durch zyklische Belastung (LEVIN et al. 2001).

\section{$2.4 \quad$ Die canine OA}

\subsection{1 Ätiologie und Diagnose}

Es liegen bisher nur wenige epidemiologische Daten zu dem Auftreten von OA bei Hunden vor. Bei einer US-amerikanischen Studie konnte 1997 festgestellt werden, dass über $20 \%$ der Hunde, die älter als ein Jahr sind, röntgenologische Anzeichen für OA aufweisen (JOHNSTON 1997). In britischen Studien konnte festgestellt werden, dass 2,5-6,6 \% der Hunde unter den Auswirkungen einer OA leiden (ANDERSON et al. 2018; O'NEILL et al. 2014). Obwohl sich die Krankheit vor allem bei älteren und größeren Hunden entwickelt, können prinzipiell Hunde jeder Rasse und jeden Alters betroffen sein. Reinrassige Hunde sind häufiger betroffen als Mischlinge und es besteht eine Rasseprädisposition bei Golden Retrievern, Labrador Retrievern, Rottweilern und Deutschen Schäferhunden. Darüber hinaus haben männliche Hunde im Vergleich zu weiblichen Hunden ein größeres Risiko, an OA zu erkranken. Eine Kastration beider Geschlechter erhöht das Risiko zusätzlich, denn durch eine Kastration entfällt die gelenksschützende Wirkung der Sexualhormone. Zudem neigen kastrierte Tiere dazu, an Gewicht zuzunehmen und werden häufiger adipös, was das Risiko für OA erhöht (ANDERSON et al. 2018).

OA tritt beim Hund typischerweise als Folgeerscheinung einer bestehenden Primärerkrankung im Bewegungsapparat auf (sekundäre OA). Dabei sind Ellenbogen-, Hüft- und Kniegelenk am häufigsten betroffen (PETTITT und GERMAN 2015). Angeborene Krankheiten, wie Hüftgelenksdysplasie, Patellaluxation oder Osteochrondrose (Osteochondrosis dissecans; $O C D)$, führen durch eine andauernde Fehlbelastung der betroffenen Gliedmaße letztendlich zu OA (HENROTIN et al. 2005). Aber auch erworbene Defekte sind oft Ausgangspunkt für OA. Folgen von Traumata, wie z.B. Frakturen, können bei einer fehlerhaften Ausheilung zu einem Stabilitätsverlust oder einer Stufenbildung im Gelenk führen, die eine $O A$ begünstigen (BÖTTCHER et al. 2007a). Auch Hunde mit Band- und Muskelverletzungen, wie z.B. einem Kreuzbandriss, entwickeln durch die bestehende Gelenksinstabilität oft degenerative Veränderungen im betroffenen Gelenk (HENROTIN et al. 2005). Wogegen die metabolische OA beim Menschen als Form der Ätiologie anerkannt ist, fehlen bisher Untersuchungen zu 
ähnlichen Prozessen beim Hund (FRYE 2016). Beim Hund wird OA oft erst im späten Stadium diagnostiziert, wenn erste klinische Symptome wie intermittierende Lahmheit auftreten und der Halter sein Tier aus diesen Gründen beim Tierarzt vorstellt. Die Tiere leiden unter Gelenksschmerz, -steifheit und -schwellung, welche die Beweglichkeit einschränken und die Lebensqualität der Tiere negativ beeinflussen (BLAND 2015). Röntgenologisch erkennbar ist eine chronische, entzündliche Reaktion des periartikulären Weichteilgewebes mit einer Schwellung und Fibrosierung, sowie Fissuren und periartikuläre Osteophyten (SZABO et al. 2007; CARRIG 1997). Neben einer röntgenologischen Untersuchung kann die Diagnose mit Hilfe von Computertomographie, Magnetresonanztomographie, Szintigraphie und Arthroskopie untermauert werden (CARRIG 1997).

\subsubsection{Therapieansätze in der caninen OA}

Da hyaliner Knorpel nur eine limitierte Fähigkeit zur Selbstheilung aufweist, zielt die derzeitige OA Therapie eher auf eine Verlangsamung der Krankheit und einer Milderung der Symptome (BLAND 2015).

Neben einer chirurgischen Therapie hat in der Tiermedizin vor allem die konservative Behandlung eine große Bedeutung. Die am häufigsten verordneten Medikamente in der konservativen Behandlung sind nichtsteroidale Antiphlogistika (NSAIDs), gefolgt von Glucocorticoiden und Nahrungsergänzungsmitteln (BOUND et al. 2011).

NSAID zielen auf eine Hemmung der COX-Enzyme und unterdrücken damit eine Bildung von proinflammatorischen Eicosanoiden wie PG, Thromboxanen und Prostacyclinen. Über diesen Mechanismus reduzieren sie die Entzündungsanzeichen und Schmerzen im Gelenk, haben jedoch keine nennenswerten krankheitsmodifizierenden Wirkungen (SMITH et al. 2011). Ein wesentlicher Nachteil sind die unter der Behandlung mit NSAIDs bei Hunden auftretenden Nebenwirkungen wie Erbrechen, Durchfall, Inappetenz, seltener gastrointestinale Ulzera, dolentes Abdomen, Ikterus, Leberenzymerhöhung sowie Polyurie und Polydipsie (MONTEIRO-STEAGALL et al. 2013). Durch den Einsatz selektiver COX-2-Hemmer konnten einige dieser Nebenwirkungen umgangen werden. Diese Gruppe der NSAID blockiert selektiv die induzierbare, meist an pathologischen Zuständen beteiligte COX-2, wogegen die physiologische COX-1 nicht beeinflusst wird (KIM und GIORGI 2013). Obwohl bei der Anwendung selektiver COX-2 Hemmer in klinischen Studien weniger Nebenwirkungen verzeichnet werden konnten, kam es in der Praxis bei Hunden dennoch zu Magenulzera und intestinalen Blutungen, sodass auch diese Gruppe der NSAIDs nicht ohne Einschränkungen angewendet werden kann (MÜNTENER et al. 2015). Beim Hund werden die COX-2 präferierenden NSAIDs Meloxicam (Metacam $®$ ) und Carprofen (Rimadyl囚) sowie die COX-2 
selektiven NSAIDs Firocoxib (Previcox®), Robenacoxib (Onsior $\left.{ }^{\circledR}\right)$, Mavacoxib (Trocoxil囚) und Cimicoxib (Cimalgex®) eingesetzt (CLINIPHARM/CLINITOX 2020a).

Corticosteroide kommen als Mittel zweiter Wahl vor allem im Endstadium der OA und bei Therapieversagen zum Einsatz (BOUND et al. 2011). Diese Wirkstoffe greifen schon über die PLA2 in die Entzündungskaskade ein und hemmen sowohl die COX als auch die Lipoxygenasen (LOX). Dadurch beeinflussen sie effektiv die Entzündungskaskade und verbessern die Lebensqualität der Tiere. Unerwünscht ist ihr Eingriff in den Stoffwechsel des gesamten Körpers, unter anderem den Wasser- und Elektrolythaushalt, das Immunsystem, die Hypothalamus-Hypophysen-Nebennierenrinden-Achse und den Intermediärstoffwechsel (CLINIPHARM/CLINITOX 2020b). Sie bedingen dadurch eine Vielzahl oft heftiger Nebenwirkungen wie iatrogenes Morbus Cushing, Diabetes, gastrointestinale Ulzera, Polydipsie, Polyurie, Polyphagie mit Gewichtszunahme und ausgeprägte immunsuppressive Effekte (BLAND 2015).

Im Jahre 2017 ist zudem ein neuer vielversprechender Wirkstoff zur Behandlung der caninen Osteoarthrose auf den Markt gekommen. Grapiprant (Galliprant®) beeinflusst im Gegensatz zu NSAID und Corticosteroiden nicht die Produktion der Eicosanoide, sondern blockiert den EP-4 Rezeptor und damit selektiv die Signalkaskade von PGE2 (KIRKBY SHAW et al. 2016). In einer Studie mit an OA erkrankten Hunden konnte eine ähnliche Effektivität und geringere Nebenwirkungen im Vergleich zu NSAID nachgewiesen werden (RAUSCH-DERRA et al. 2016). Bis heute existieren jedoch nur wenige Studien zum Langzeiteinsatz von Grapiprant.

Neben der konservativen und medikamentösen Behandlung von OA stellt eine chirurgische Versorgung arthrotischer Gelenke eine wichtige Alternative zur Prophylaxe und Therapie dar. Operationen können die Gelenkinkongruenz bei vererbten Dysplasien korrigieren oder die Heilung von Frakturen unterstützen (COOK und PAYNE 1997). Im Endstadium der Krankheit bleiben oft nur eine Schmerzabschirmung durch Denervation (KINZEL et al. 2002) oder der vollständige Gelenksersatz durch eine Endoprotese (ALLEN 2012). Alle chirurgischen Behandlungsmöglichkeiten sind kostspielig und mit Risiken verbunden, sodass sie nicht für jedes Tier in Frage kommen. In Zukunft könnte eine Transplantation von gesundem Knorpelgewebe in beschädigte Bereiche eine neue Behandlungsmöglichkeit darstellen (FITZPATRICK et al. 2009; BÖTTCHER et al. 2007b). Unterstützend zu den genannten Therapiemöglichkeiten wird Physiotherapie, Akupunktur und vor allem bei übergewichtigen Tieren eine Gewichtsreduktion zur Gelenksentlastung angeraten (BOUND et al. 2011). Diese Maßnahmen erfordern jedoch eine hohe Besitzer-Compliance und sind daher nicht immer umsetzbar. 
Auf der Suche nach verträglicheren und krankheitsmodifizierenden neuen Behandlungsmöglichkeiten rücken die Nahrungsergänzungsmittel bei Menschen und Tieren zunehmend in den Fokus der Forschung. So gibt es für Hunde ein großes Angebot an frei verkäuflichen Ergänzungsfuttermitteln in Form von Ölen, Pulvern und Tabletten auf Basis von Tierprodukten, Enzymen, Vitaminen- und Mineralstoffen. Diese Mittel zählen je nach Zusammensetzung laut $\S 3 \mathrm{Nr}$. 15 des LEBENSMITTEL-UND FUTTERMITTELGESETZBUCHS zu den Diätfuttermitteln oder laut Artikel 3 Absatz 2 Buchstabe j der VERORDNUNG (EG) NR. 767/2009 zu den Ergänzungsfuttermitteln. Damit fallen sie nicht unter die Zulassungsbeschränkungen für Arzneimittel und können ohne Rücksprache mit einem Tierarzt vom Tierhalter angewendet werden. Klinische Studien zur Wirksamkeit dieser Präparate existieren zu Glucosaminen, Chondroitinsulfat, unverseifbaren Bestandteilen aus Sojabohnen oder Avocado, Grünlippmuschelextrakt, „Auszüge“ aus grünem Tee und Curcumin. Die beobachteten klinischen Effekte sind oft nur marginal und auf Grund methodischer Mängel in der Durchführung vieler Studien von fraglicher Bedeutung. Kritikpunkte sind unter anderem eine geringe Studienanzahl insgesamt, die mangelnde Randomisierung, fehlende objektive Untersuchungskriterien wie Kraftplattenmessungen, geringe Stichprobengröße und große Variabilität in Dauer und Dosis mit einer daraus resultierenden schlechten Vergleichbarkeit untereinander. Eine wichtige Ausnahme stellen die klinischen Studien zur Fütterung von n-3 mehrfach ungesättigten Fettsäuren (PUFAs) aus Fischöl dar (COMBLAIN et al. 2016; VANDEWEERD et al. 2012).

\subsection{Mehrfach ungesättigte Fettsäuren (PUFAs) als Ergänzungsfuttermittel}

\subsubsection{Grundlagen des Fettsäurestoffwechsels}

Nicht essentielle Fettsäuren können vom Körper aus Acetyl-Coenzym A selbst synthetisiert werden und kommen in großen Mengen in tierischen Zellen vor. Zu diesen Fettsäuren gehören die gesättigten Fettsäuren Palmitinsäure und Stearinsäure sowie die n-9 einfach ungesättigte Fettsäure Ölsäure. Fettsäuren, die eine oder mehrere cis-Doppelbindungen im Abstand von mehr als neun C-Atomen zur Carboxylgruppe aufweisen, können hingegen vom tierischen Organismus nicht synthetisiert werden und müssen mit der Nahrung zugeführt werden. Zu diesen essentiellen Fettsäuren zählen die n-6 PUFAs Linolsäure (LA) und Arachidonsäure (AA) sowie die n-3 PUFAs a-Linolensäure (ALA), Eicosapentaensäure (EPA) und Docosahexaensäure (DHA) (LÖFFLER et al. 2007).

Dabei dienen die in Pflanzen enthaltenen essentiellen langkettigen Fettsäuren LA (18:2n-6; Sojaöl, Sonnenblumenöl und Maisöl) und ALA (18:3n-3; Walnussöl und Leinöl) als Ausgangssubstrat für Fettsäuren mit einer längeren Acylkette und mehr Doppelbindungen. 
Mittels Elongasen, $\Delta-6$ Desaturase und $\Delta-5$ Desaturase entsteht aus n-6 LA die semiessentielle Fettsäure AA (20:4n-6) und aus n-3 ALA die semiessentielle Fettsäure EPA (20:5n-3). DHA (22:6n-3), als extralangkettige Fettsäure mit sechs Doppelbindungen, benötigt für die Synthese aus EPA zusätzlich zur $\Delta-6$ Desaturase und zur Elongase einen Zyklus der B-Oxidation (CALDER 2015; CURTIS et al. 2004). Die Umsatzraten dieser Reaktionen variieren jedoch für alle Fettsäuren. So erfolgt die Konversion von ALA zu EPA, im Vergleich zur Konversion von LA zu AA, nur zu einer geringen Rate von 20\%. Die anschließende Umwandlung zu DHA liegt beim Menschen unter 1\% (ARTERBURN et al. 2006). Auch bei Hunden ist die Konversionsrate nachweislich sehr gering (BAUER 2007; HARRIS et al. 2007). Eine Steigerung des Blutspiegels von DHA erfolgt demnach nur nach Supplementierung von DHA und nicht nach Gabe von ALA oder EPA (BRENNA et al. 2009). Eine verlässliche Quelle für EPA und DHA sind Lebensmittel maritimer Herkunft und Fischöle, welche bis zu $30 \%$ von beiden Fettsäuren enthalten können (CALDER 2015).

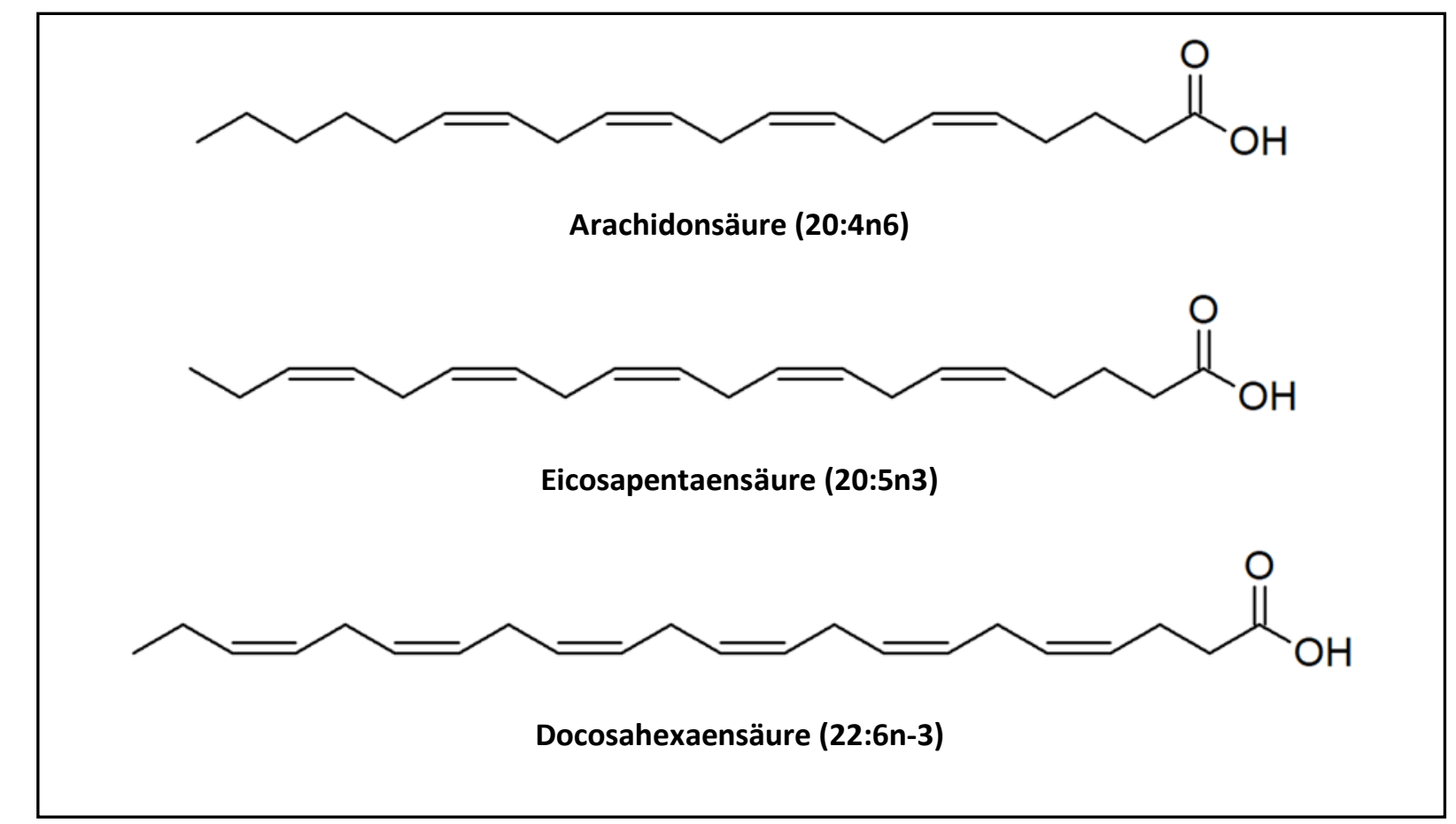

Abbildung 3: Strukturformeln der n-3 und n-6 Fettsäuren, welche in dieser Arbeit zur Verwendung kamen.

\subsubsection{Fettsäurestoffwechsel im Knorpelgewebe}

Trotz seines geringen Anteils an Lipiden (<1\%) (STOCKWELL 1967) hat das Knorpelgewebe eine einzigartige Lipidzusammensetzung und einen außergewöhnlichen Lipidmetabolismus (VILLALVILLA et al. 2013). Im gesunden, adulten Knorpel dominieren vor allem gesättigte Fettsäuren und n-9 Fettsäuren, wogegen n-3 und n-6 Fettsäuren nur einen kleinen Anteil des 
Fettsäuremusters ausmachen (XU et al. 1994; ADKISSON et al. 1991). Die Zusammensetzung der Lipide variiert zwischen den einzelnen Knorpelzonen. In den oberflächlichen Zonen befinden sich die Lipide größtenteils extrazellulär in der ECM, wogegen sie in den tiefen Zonen vor allem intrazellulär in Form von Lipidvakuolen vorliegen (MANSFIELD und WINLOVE 2017). Zudem verändert sich die Fettsäurezusammensetzung und der Gesamtgehalt an Lipiden im Alter und bei OA (CLELAND et al. 1995; ADKISSON et al. 1990).

Chondrozyten sind befähigt, zugeführte Fettsäuren in großem Maße in ihr Fettsäuremuster zu integrieren und zu verstoffwechseln (XU et al. 1994; NAGAO et al. 1991; LIPPIELLO 1990). Bedingt durch die isolierte Lage im Gelenksspalt und die fehlende Versorgung mit Blutgefäßen hat hyalines Knorpelgewebe allerdings nur einen sehr limitierten Zugang zu Nährstoffen und damit auch zu Lipiden. Die Versorgung erfolgt hauptsächlich durch Diffusion aus der Synovialflüssigkeit (WANG et al. 2013b) und in geringem Maße auch durch die Gefäße im anliegenden Knochen (PAN et al. 2009). Größe und Ladung der Moleküle bestimmen wesentlich die Verfügbarkeit, da jedes Molekül sich erst durch die negativ geladene und dichte ECM bewegen muss, um zu den Zellen zu gelangen. Fettsäuren werden im Blut vor allem in Form von Lipoproteinen und gebunden an Albumin transportiert und liegen demnach in großen Komplexen vor. Vor ihrem Eintritt in die ECM lösen sich die Fettsäuren von den Transportproteinen und diffundieren durch die Matrix (ARKILL und WINLOVE 2006). Untersuchungen zeigen, dass vor allem tiefe Zonen bei der Versorgung mit Lipiden benachteiligt sind (MANSFIELD und WINLOVE 2017). Man geht allerdings davon aus, dass bei OA der Transport durch die degenerierte Matrix und Gefäßeinsprossung in den Knorpel insgesamt erleichtert ist (PAN et al. 2012; LOTKE und GRANDA 1972).

\subsection{3 n-3 PUFAs als Therapieoption bei caniner OA}

Während in vivo Ernährungsstudien bei Menschen bisher nur inkonsistente Ergebnisse liefern (BOE und VANGSNESS 2015), zeigen canine Studien bei OA meist eine signifikante Verbesserung der klinischen Symptome. So beschreiben Tierärzte und Besitzer unter fischölreichen Diäten eine bessere Beweglichkeit sowie geringere Schmerzhaftigkeit und damit eine positive Auswirkung auf die Lebensqualität der betroffenen Tiere (MEHLER et al. 2016; FRITSCH et al. 2010a; FRITSCH et al. 2010b; ROUSH et al. 2010a; ROUSH et al. 2010b). Darüber hinaus konnten objektive Messungen mit Kraftplatten eine stärkere Belastung betroffener Gliedmaßen dokumentieren (HIELM-BJÖRKMAN et al. 2012; ROUSH et al. 2010a). Zudem kann das Auftreten röntgenologischer Anzeichen für eine OA nach einer TPLO (Tibial Plateau Leveling Osteotomy) hinausgezögert werden (VERPAALEN et al. 2018). 
Der dahinterstehende Mechanismus ist bis heute nicht vollständig geklärt, man geht jedoch davon aus, dass es sich um ein multifaktorielles Geschehen handelt. Eine Erklärungsmöglichkeit besteht in der Umsetzung der Fettsäuren in bioaktive Lipidmediatoren. So konkurriert die n-3 PUFA EPA mit der n-6 PUFA AA um den Einbau in die Phosphoglyceride der Zellmembran. Die n-6 PUFA AA wird mittels der COX- und LOX-Enzyme in proinflammatorische Eicosanoide wie $P G$ der Klasse 2 und Leukotriene der Klasse 4 umgewandelt. Sobald jedoch anstelle der n -6 PUFA AA die n-3 PUFA EPA in die Zellmembran eingebaut wird, kommt es stattdessen zur Bildung weniger potenter Lipidmediatoren wie $P G$ der Klasse 3 und Leukotriene der Klasse 5. Man geht davon aus, dass diese Derivate auf Grund ihrer geringeren Affinität zum Eicosanoidrezeptor eine eher antinflammatorische Wirkung haben und damit dem pathologischen, chronischen Entzündungszustand der $\mathrm{OA}$ entgegenwirken (CALDER 2015; LOPEZ 2012; SMITH et al. 2011). Darüber hinaus hemmen die n-3 PUFAs den AA-Metabolismus und die Expression der COX-2 und LOX-5 (SMITH et al. 2011; HURST et al. 2009; CURTIS et al. 2002a; CURTIS et al. 2002b) und verringern damit zusätzlich die Umsetzung der noch bestehenden AA in proinflammatorische Eicosanoide. Neben den Eicosanoiden können die n-3 PUFAs DHA und EPA in eine Vielzahl weiterer Lipidmetabolite umgesetzt werden, unter anderem Resolvine, Maresine, (Neuro-)Protectine und Endocannabinoide, welche ihrerseits eine antiinflammatorische und analgetische Wirkung vermitteln (CALDER 2015; WEYLANDT et al. 2012). Darüber hinaus wirken sich Diäten, welche reich an n-3 PUFAs sind, positiv auf die Mitochondrienfunktion aus und verändern die Membran-Fluidität (NICOLSON und ASH 2014). Eher spekulativ ist bisher die positive Wirkung der n-3 PUFAs auf die Schmerzweiterleitung (LOPEZ 2012).

In in vitro Modellen für OA reduzierte eine Supplementierung mit EPA und DHA die Expression der proinflammatorischen Zytokine IL-1 $\beta$, IL-1 $\alpha$ und TNF- $\alpha$, die Expression diverser MMP- und ADAMTS-Enzyme sowie COX-2 und PGE2 (HURST et al. 2009; ZAINAL et al. 2009; CURTIS et al. 2002a; CURTIS et al. 2002b). Zudem fiel in Explantkulturen die IL-induzierte Freisetzung von Glykosaminoglykanen aus der ECM unter Einfluss von EPA und DHA deutlich geringer aus (WANN et al. 2010; CURTIS et al. 2002a; CURTIS et al. 2002b). Diese Ergebnisse konnten teilweise in caninen Fütterungsversuchen bestätigt werden (VERPAALEN et al. 2018; HANSEN et al. 2008). Alle in vitro Untersuchungen beschränken sich bisher jedoch auf bovine und humane Chondrozyten.

Wahrscheinlich ebenfalls vorteilhaft für den Krankheitsverlauf ist die Wirkung von n-3 PUFAs auf das gesamte Immunsystem. Bei Menschen ist bekannt, dass n-3 PUFAs die Expression von Leukozyten-Adhäsionsmolekülen hemmen, die Freisetzung von Signalmolekülen durch die Veränderung von Lipid Rafts unterbinden und die T-Zell Proliferation beeinflussen (CALDER 2015). Untersuchungen an Hunden zeigen eine Beeinflussung des gesamten 
Immunstatus des Körpers. So verbesserten Ergänzungsfuttermittel in Form von Fischöl die Phagozytoseleistung der Immunzellen (BAUER 2007) und reduzierten diverse oxidative Marker im Blut (BARROUIN-MELO et al. 2016).

Nicht zuletzt aus diesen Gründen erwies sich bei Hunden die Einnahme von Fischöl als vorteilhaft bei einer Vielzahl von anderen Erkrankungen, welche mit einem chronischen Entzündungsstatus einhergehen, wie malignem Lymphom (OGILVIE et al. 2000), Herzinsuffizienz (SMITH et al. 2007), Niereninsuffizienz (BROWN et al. 2000) und chronisch entzündlichen Darmerkrankungen (IBD) (ONTSOUKA et al. 2012). 


\section{ZIEL DER ARBEIT}

Obwohl eine vorteilhafte Wirkung von Fischöl in der OA beim Hund als gesichert gilt, liegen derzeit kaum Studien vor, welche die zugrundeliegenden Mechanismen entschlüsseln. In vitro Studien an bovinen und humanen Chondrozyten zeigen unter der Supplementierung mit n-3 PUFAs eine Reduktion von Matrixproteinasen, COX und proinflammatorischen Zytokinen (WANN et al. 2010; ZAINAL et al. 2009; HURST et al. 2009; CURTIS et al. 2002a; CURTIS et al. 2002b). Ein ähnlicher Mechanismus ist auch beim Hund denkbar. Diese Studie soll nun dazu dienen, die molekularen Wirkmechanismen der n-3 PUFAs EPA und DHA in der caninen OA genauer zu untersuchen.

Dafür wurde im ersten Schritt ein Protokoll zur Isolierung, Anzucht und Kryokonservierung für canine Chondrozyten etabliert. Die Ansprechbarkeit der Zellen auf das katabole Zytokin IL-1 $\beta$ und das anabole Zytokin TGF- $\beta$ wurde getestet und auf Basis dieser Untersuchungen ein Modell für die canine OA entwickelt.

Im nächsten Schritt wurde das Modell mit AA, EPA und DHA supplementiert, um die Fettsäureaufnahme und den Fettsäuremetabolismus von caninen Chondrozyten zu untersuchen.

Im letzten Schritt wurde der Effekt von AA, EPA und DHA auf ausgewählte Schlüsselproteine der Entzündung und Matrixdegeneration in einem Modell der caninen OA getestet. Der Fokus lag dabei auf der Supplementierung von geringen Dosen über längere Zeiträume, um der in vivo Situation im caninen Gelenk nach der Aufnahme von Diäten mit Fischöl nahe zu kommen. 


\section{ERGEBNISSE}

\subsection{Publikation 1}

Effects of transforming growth factor- $\beta$ and interleukin-1 $\beta$ on inflammatory markers of osteoarthritis in cultured canine chondrocytes

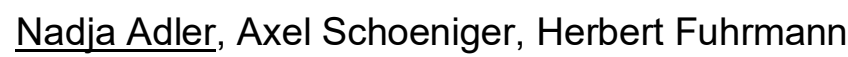

Publiziert im: American Journal of Veterinary Research 2017; 78(11): 1264-1272

Doi: 10.2460/ajvr.78.11.1264

\section{Eigenanteile der einzelnen Autoren}

Nadja Adler

$\diamond$ Gewinnung der Daten

$\diamond$ Analyse der Daten

$\diamond$ Interpretation der Daten

$\diamond$ Zusammenstellung der Publikation

$\underline{\text { Axel Schoeniger }}$

$\diamond \quad$ Analyse der Daten

$\diamond$ Interpretation der Daten

$\diamond$ Durchsicht und Korrektur der Publikation

\section{Herbert Fuhrmann}

$\diamond \quad$ Zielstellung und Aufbau der Studie

$\diamond$ Interpretation der Daten

$\diamond$ Durchsicht und Korrektur der Publikation 


\section{Effects of transforming growth factor- $\beta$ and interleukin-I $\beta$ on inflammatory markers of osteoarthritis in cultured canine chondrocytes}

\author{
Nadja Adler DVM \\ Axel Schoeniger Dipl Biochem, Dr Rer Nat \\ Herbert Fuhrmann DVM, Prof Dr Med Vet \\ Received November 23, 2016 \\ Accepted February 14, 2017.
}

From the Faculty of Veterinary Medicine, Institute of Biochemistry, University of Leipzig, 04103 Leipzig, Germany. Ms. Adler's present address is Kleintierpraxis und Tierärztliche Klinik für Kleintiere, Gartenstraße 12, 26I22 Oldenburg, Germany.

Address correspondence to Dr. Fuhrmann (fuhrmann@vmf.uni-leipzig.de).

\begin{abstract}
OBJECTIVE
To determine effects of transforming growth factor (TGF)- $\beta$ and interleukin (IL)-I $\beta$ on inflammatory markers in cultured canine chondrocytes to clarify the role of these cytokines in osteoarthritis of dogs.
\end{abstract}

\section{SAMPLE}

Pooled chondrocytes isolated from the stifle joints of 4 adult dogs.

\section{PROCEDURES}

Chondrocytes were isolated, cultured, and frozen at $-80^{\circ} \mathrm{C}$. Pooled cells were incubated in medium with or without TGF- $\beta$ (I or $10 \mathrm{ng} / \mathrm{mL}$ ) and subsequently stimulated with IL-I $\beta(10 \mathrm{ng} / \mathrm{mL})$. Concentrations of nitric oxide (NO) and prostaglandin (PG) E were measured in culture supernatants. Gene expression of matrix metalloproteinase (MMP)-3, tissue inhibitor of metalloproteinase (TIMP)-2, inducible NO synthase (iNOS), and cyclooxygenase (COX)-2 was quantified by use of real-time quantitative PCR assays.

\section{RESULTS}

Stimulation with IL-I $\beta$ increased gene expression of all inflammatory markers, except for TIMP-2. Incubation with TGF- $\beta$ resulted in a significant decrease in MMP-3 and TIMP-2 mRNA concentrations but had no effect on PGE and NO concentrations. For cells treated with TGF- $\beta$ followed by IL-I $\beta$, concentrations of PGE and NO were lower, compared with concentrations for IL-I $\beta$ control cells. Furthermore, IL-I $\beta$-induced gene expression of iNOS, MMP-3, and COX-2 was downregulated. However, the IL-I $\beta$ induced downregulation of TIMP-2 gene expression was partially restored by pretreatment with TGF- $\beta$.

\section{CONCLUSIONS AND CLINICAL RELEVANCE}

Results indicated that IL-I $\beta$ increased the expression of inflammatory genes and mediators, and TGF- $\beta$ largely attenuated the IL-I $\beta$-mediated inflammatory response. Therefore, TGF- $\beta$ might be a novel target for use in the prevention and treatment of cartilage breakdown in dogs with osteoarthritis. (Am J Vet Res 2017;78:1264-1272)
$\mathrm{H}$ yaline cartilage is a highly complex connective tissue that resists compression in articular joints and protects bones from friction. ${ }^{1}$ Healthy functional cartilage is characterized by a balance between anabolic and catabolic factors. Disturbance of this balance may result in excessive inflammation that ultimately leads to the breakdown of cartilage. This process has been implicated in the pathogenesis of osteoarthritis. $^{2}$

$\begin{array}{ll}\text { ABBREVIATIONS } \\ \text { COX } & \text { Cyclooxygenase } \\ \text { GAPDH } & \text { Glyceraldehyde-3-phosphate dehydrogenase } \\ \text { IL } & \text { Interleukin } \\ \text { iNOS } & \text { Inducible nitric oxide synthase } \\ \text { MMP } & \text { Matrix metalloproteinase } \\ \text { NO } & \text { Nitric oxide } \\ \text { PG } & \text { Prostaglandin } \\ \text { qPCR } & \text { Quantitative PCR } \\ \text { TBP } & \text { TATA-binding protein } \\ \text { TGF } & \text { Transforming growth factor } \\ \text { TIMP } & \text { Tissue inhibitor of metalloproteinase }\end{array}$

Osteoarthritis is a common condition in dogs. Presumably $>20 \%$ of middle-aged dogs in the United States have osteoarthritis. ${ }^{3}$ Similar to the condition in humans, affected dogs have signs of joint pain and restricted mobility; thus, they often have a diminished quality of life. ${ }^{3}$ Methods have been used to mimic osteoarthritis in dogs for in vitro evaluation of this inflammatory disease. ${ }^{4-7}$

Several factors derived from chondrocytes and synoviocytes play a major role in the initiation and progression of osteoarthritis. Among them, IL-1 $\beta$ is considered one of the most important. ${ }^{8}$ Once IL-1 $\beta$ is bound to the IL-1 receptor, various catabolic pathways are induced, which include the expression of proteolytic enzymes (eg, MMPs and aggrecanases). Major components of the extracellular matrix are broken down ${ }^{6,9-11}$ and mediators (eg, NO and PGE) are produced, which leads to inflammation in the joint. ${ }^{12-14}$ Furthermore, anabolic activity of the cells is suppressed, which leads to delayed healing of the 
resulting cartilage defects. ${ }^{15,16}$ Interleukin- $1 \beta$ also has the potential to induce a variety of chemokines that attract other cells to the joint. These cells generate additional inflammatory and proteolytic mediators, ${ }^{17,18}$ which may result in total cartilage destruction.

Transforming growth factor- $\beta$ is a supplement commonly added to chondrocyte cell cultures and has been used as a trigger for chondrogenic differentiation of mesenchymal stem cells. ${ }^{19,20}$ However, the actions of TGF- $\beta$ on chondrocytes remain controversial because it has been found that TGF- $\beta$ provides both stimulatory and inhibitory effects on cartilage metabolism. On the one hand, TGF- $\beta$ promotes the production of matrix components in chondrocytes ${ }^{21}$ and plays a key role in chondrogenesis ${ }^{22}$ and cartilage repair. ${ }^{23}$ Furthermore, TGF- $\beta$ attenuates IL-1 $\beta$-stimulated NO production ${ }^{24}$ and has proven beneficial for matrix protection because it modulates secretion of TIMPs $^{25}$ and decreases the synthesis of MMPs. ${ }^{26,27}$ On the other hand, TGF- $\beta$ has a number of effects that promote cartilage breakdown, which include the synthesis of matrix-degenerating enzymes, ${ }^{28,29}$ the development of osteophytes, ${ }^{30}$ and the initiation of fibrosis. ${ }^{22}$ In vivo experiments have revealed that prolonged administration of high doses of TGF- $\beta$ results in osteoarthritis-like cartilage defects. ${ }^{31}$ However, moderate doses of TGF- $\beta$ may be a potential treatment for osteoarthritis. ${ }^{32}$

The effects of TGF- $\beta$ on canine chondrocytes have not been elucidated. Therefore, the purpose of the study reported here was to use cultured canine chondrocytes to investigate the effects of TGF- $\beta$ on chondrocytes stimulated with IL-1 $\beta$. We hypothesized that TGF- $\beta$ would exert positive effects on matrix metabolism and, moreover, inhibit the destructive effects of IL-1 $\beta$.

\section{Materials and Methods}

\section{Sample}

Full-thickness cartilage slices were aseptically obtained from the stifle joints of 4 dogs (mixed-breed dogs; median age, 12 years) within 24 hours after the dogs were euthanized for reasons unrelated to the present study. Carcasses were stored in a cold room $\left(7^{\circ} \mathrm{C}\right)$ from time of euthanasia until harvest of cartilage slices. Dogs were eligible for inclusion in the study if they had no orthopedic abnormalities in the stifle joints and no current systemic diseases that could have interfered with the growth and viability of chondrocytes.

\section{Chondrocyte isolation and in vitro culture}

Cells were cultured and harvested as described elsewhere, ${ }^{33}$ with slight modifications. Briefly, slices of macroscopically normal articular cartilage were digested in an enzyme mixture at $37^{\circ} \mathrm{C}$ for 18 hours with constant agitation. The enzyme mixture consisted of collagenase $^{\mathrm{a}}(1 \mathrm{U} / \mathrm{mL})$, another collagenase $\mathrm{b}^{\mathrm{b}}(330 \mathrm{U} /$ $\mathrm{mL})$, and hyaluronidase ${ }^{\mathrm{c}}(30 \mathrm{U} / \mathrm{mL})$ diluted in Dulbecco modified Eagle medium (high glucose) that was supplemented with $10 \%$ fetal calf serum and $1 \%$ penicillinstreptomycin. After enzymatic digestion was completed, cells were separated by filtration through a $100-\mu \mathrm{m}$ nylon mesh, centrifuged at $400 \times g$ for 20 minutes, and washed twice with PBS solution. Viability and cell numbers were determined by use of trypan blue dye exclusion in a Neubauer chamber, and cells were plated in culture flasks at a density of $2 \times 10^{4}$ cells $/ \mathrm{cm}^{2}$. Freshly isolated cells were maintained in Dulbecco modified Eagle medium (high glucose) with $10 \%$ fetal calf serum and $1 \%$ penicillin-streptomycin, enriched with $10 \mathrm{ng}$ of human recombinant insulin $/ \mathrm{mL}$ and $50 \mu \mathrm{g}$ of phosphoascorbic acid-trisodium salt/mL (basic medium), and incubated at $37^{\circ} \mathrm{C}, 5 \% \mathrm{CO}_{2}$, and $95 \%$ humidity (passage 0 ). Culture medium was replaced with basic medium every 2 to 3 days. After confluency was reached, cells were detached with $0.05 \%$ trypsin-EDTA, centrifuged at 400 $\mathrm{X} g$ for 20 minutes, and washed once with PBS solution. Cells from each donor were resuspended in antimicrobial-free basic medium with 5\% dimethyl sulfoxide at a density of $1 \times 10^{6}$ cells/cryovial and frozen at $-80^{\circ} \mathrm{C}$.

Cells harvested from each of the 4 canine cadaver donors were cultured separately (passage 0 ). They were pooled prior to the respective experiments (passage 1).

\section{Experimental design}

Canine IL-1 $\beta^{\mathrm{d}}$ was obtained as a solid lyophilized powder, reconstituted in sterile distilled water to a concentration of $50 \mu \mathrm{g} / \mathrm{mL}$, and placed in aliquots and frozen at $-20^{\circ} \mathrm{C}$ until usage. Frozen cells pooled from all 4 canine cadaver donors were thawed, diluted with basic medium, and centrifuged at $1,200 \times g$ for 6 minutes. The cell pellet was resuspended in basic medium (with $5 \%$ fetal calf serum), and cells were counted and seeded onto 6-well plates at a density of $1.8 \times 10^{5}$ cells/well (passage 1). During incubation, plates were maintained at $37^{\circ} \mathrm{C}$ with $5 \% \mathrm{CO}_{2}$ and $95 \%$ humidity. To investigate the effects of TGF- $\beta$, cells were incubated in basic medium alone or basic medium containing 1 or $10 \mathrm{ng}$ of canine TGF- $1 \beta / \mathrm{mL}$. Cultures were incubated for 48 hours, and cells then were incubated with (stimulated) or without $10 \mathrm{ng}$ of IL- $1 \beta / \mathrm{mL}$ for another 24 hours in basic medium supplemented as described previously. The incubation time of 24 hours was chosen on the basis of a previous study 5 in which investigators found that the first peak of inflammatory marker release in osteoarthritis models occurs after cells have been incubated for 24 hours. After cultures were incubated for 72 hours, cells and culture supernatants were collected and stored at $-80^{\circ} \mathrm{C}$ for subsequent assessment of PGE and NO concentrations and gene expression. All samples were prepared in triplicate. At the end of the experiment, the total yield of chondrocytes was $4 \times 10^{5}$ cells/well.

\section{Histologic examination of extracellular matrix}

Cells were examined daily by use of phase-contrast microscopy during in vitro culture. Extracellular matrix production was visible by use of Alcian blue 
stain. Cells of passage 0 and passage 1 were grown in monolayer, as described previously. After confluency was reached, cells were fixed with $10 \%$ formaldehyde for 15 minutes, incubated in $3 \%$ acetic acid for 3 minutes, and then incubated with $1 \%$ Alcian blue salt solution $^{c}$ for 3 hours. Phase-contrast microscopy of stained cells was performed, and photographs were obtained of representative specimens.

\section{Gene expression analysis}

Total RNA was extracted from the cells with a commercially available $\mathrm{kit}^{\mathrm{f}}$ used in accordance with the manufacturer's instructions. Contaminating residual genomic DNA was removed with an endonuclease. ${ }^{g}$ Purity and concentration of RNA were determined by absorbance measurement at 260 and $280 \mathrm{~nm} .^{\text {h }}$ For each sample, $500 \mathrm{ng}$ of RNA was reverse transcribed into cDNA by use of a commercial $\mathrm{kit}^{\mathrm{i}}$ and thermal cycler. ${ }^{j}$ Relative gene expression of MMP- $3,{ }^{34}$ TIMP- $2,{ }^{35}$ iNOS, ${ }^{36}$ and COX-2 $2^{5}$ and the reference genes $\mathrm{TBP}^{37}$ and GAPDH $^{38}$ (Appendix) was analyzed by use of a commercially available PCR assay $\mathrm{kit}^{\mathrm{k}}$ and real-time detection system. ${ }^{1}$ Final volume of reaction samples was 20 $\mu \mathrm{L}$, which consisted of $10 \mu \mathrm{L}$ of master mix, ${ }^{\mathrm{k}} 400 \mathrm{nM}$ of forward primer, $400 \mathrm{nM}$ of reverse primer, and $1 \mu \mathrm{L}$ of cDNA diluted 1:10 in PCR-grade water. Previously validated primers for target and reference genes were used. The amplification efficiency for each gene was determined from the slope of a standard curve generated by performing qPCR assays with a logarithmic dilution of the template DNA. All reactions were performed in triplicate by use of the following cycling conditions: initial denaturation at $95^{\circ} \mathrm{C}$ for 3 minutes, which was followed by 40 cycles of denaturation at $95^{\circ} \mathrm{C}$ for 3 seconds, annealing at the appropriate temperature for 20 seconds, and extension at $72^{\circ} \mathrm{C}$ for 1 second. Control samples (no reverse transcriptase and no template) were included in each assay. To verify specificity of the PCR assay products, a melting curve analysis was performed by heating the samples from $55^{\circ}$ to $99^{\circ} \mathrm{C}$ in $1^{\circ} \mathrm{C}$ increments with continuous measurement of fluorescence. Relative expression was obtained by normalizing target gene expression to that of the reference genes TBP and GAPDH. The change in gene expression for each sample was calculated by use of computer software. ${ }^{\mathrm{m}}$

\section{Assay of NO concentrations}

Nitric oxide is a short-lived free radical that is rapidly metabolized to nitrite. Therefore, the nitrite concentration was quantified by use of a calorimetric assay and used as an indicator of NO production. Briefly, $50 \mu \mathrm{L}$ of Griess reagent (1:1 mixture of $0.1 \%$ sulfanilamide in $5 \%$ phosphoric acid and $0.1 \%$ $\mathrm{N}$-naphthyl-ethylenediamine dihydrochloride) was added to $50 \mu \mathrm{m}$ of cell culture supernatant and allowed to incubate for 10 minutes. Absorbance then was measured at $540 \mathrm{~nm}$ on a plate reader. ${ }^{\mathrm{n}}$ A standard curve was generated from solutions containing 0 to $6 \mu \mathrm{g}$ of sodium nitrite $/ \mathrm{mL}^{\circ}{ }^{\circ}$

\section{Assay of PGE concentrations}

Stored supernatants were thawed and assayed for PGE concentration by use of a commercially available enzyme immunoassay kit $^{p}$ that was used in accordance with the manufacturer's instructions. Optical density was measured at $450 \mathrm{~nm}$ on a plate reader. ${ }^{\mathrm{q}}$ Assay specificity was approximately $100 \%$ for $\mathrm{PGE}_{2}$. Cross-reactivity was $100 \%$ for $\mathrm{PGE}_{3}$ and $27 \%$ for $\mathrm{PGE}_{1}$.

\section{Statistical analysis}

Data for the real-time qPCR assay were analyzed as logarithmic (base 2) ratios of expression. The study was conducted as 3 separate experiments in duplicate for PGE and NO concentrations and in triplicate for gene expression analysis by use of pooled cells from the 4 canine cadaver donors. To compare the effects of TGF- $\beta$ and IL- $1 \beta$, all data were analyzed with a 2 -factor ANOVA by use of a statistical program. ${ }^{\mathrm{r}}$ When there was a significant main effect of TGF- $\beta$ or IL-1 $\beta$ or an interaction between TGF- $\beta$ and IL-1 $\beta$, a Bonferroni post hoc test was performed to detect differences between means. Significance for the ANOVA and post hoc test was set at $\alpha=0.01$.

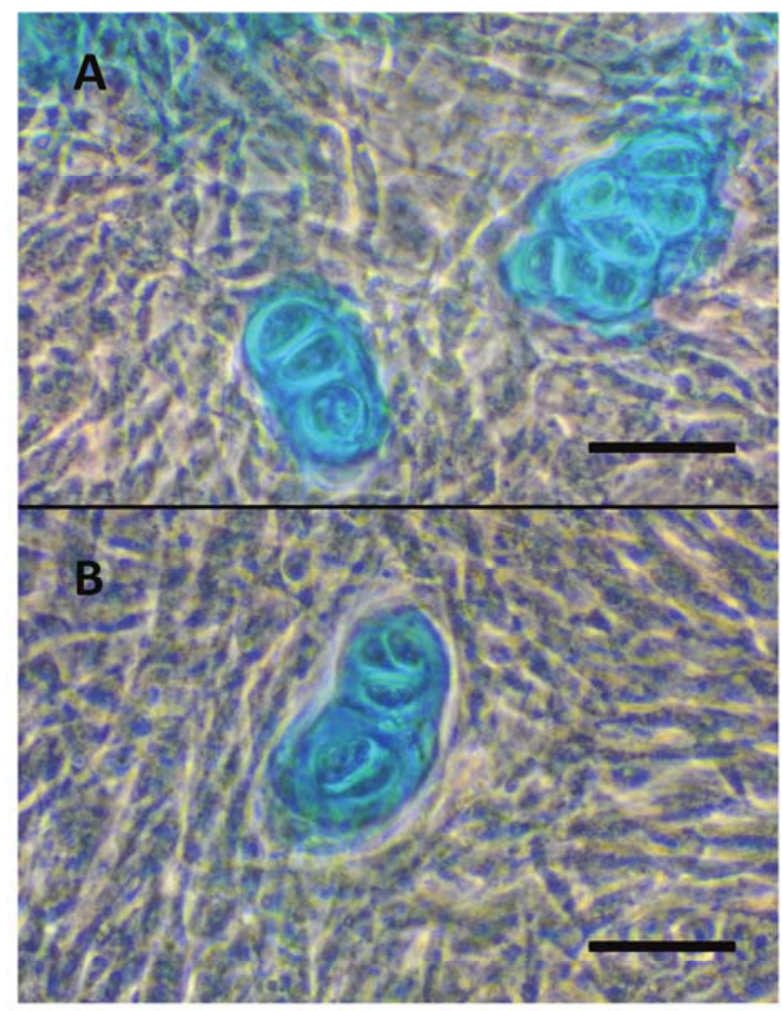

Figure I-Photomicrographs of canine chondrocytes isolated and cultured in monolayer for 10 days (passage $0 ; A$ ) and isolated, cultured in monolayer for 10 days, frozen at $-80^{\circ} \mathrm{C}$, and then cultured for another 5 days (passage I; B). Notice that chondrocytes of both passages form clusters of round cells and are encapsulated in extracellular matrix. Alcian blue stain; bar $=250 \mu \mathrm{m}$. 


\section{Results}

\section{Chondrocyte in vitro culture}

Examination after application of trypan blue dye stain revealed that viability of the isolated chondrocytes was $>90 \%$. Cells adhered to the bottom of the flasks within 24 to 72 hours after seeding. There was no appreciable variation of viability between cultured cells isolated from the various donors. Cells in monolayer appeared small and had a polygonal shape, although clusters of round cells remained. Cells in clusters were encapsulated in metachromatic materi-
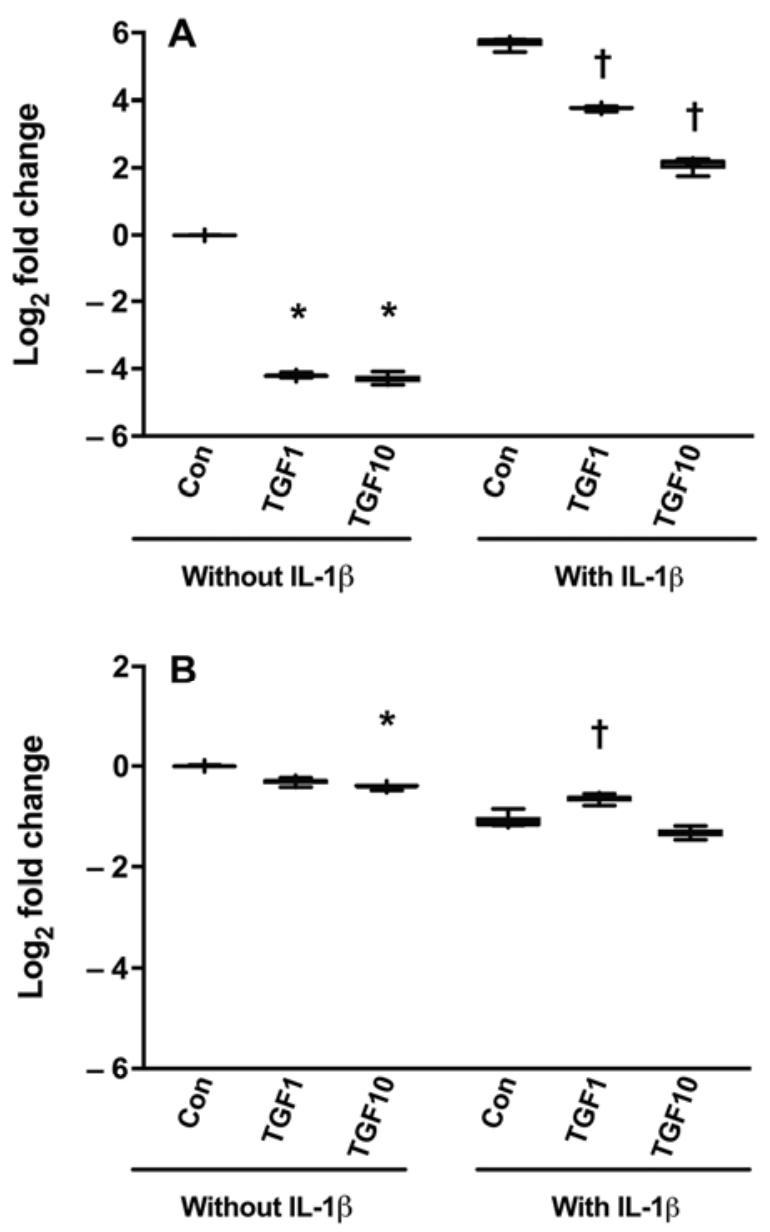

Figure 2-Box-and-whisker plots of the effects of TGF- $\beta$ on mRNA concentrations for MMP-3 (A) and TIMP-2 (B). Canine chondrocytes obtained from 4 canine cadavers were incubated (in triplicate) in medium supplemented with I $\mathrm{ng}$ of TGF- $\beta / \mathrm{mL}$ (TGFI) and $10 \mathrm{ng}$ of TGF- $\beta / \mathrm{mL}$ (TGFI0) for 48 hours followed by incubation with or without IL-1 $\beta(10 \mathrm{ng} / \mathrm{mL})$ for 24 hours. Data were normalized on the basis of mRNA concentrations for the housekeeping genes GAPDH and TBP and reported as $\log _{2}$-fold changes relative to results for the untreated control cells (Con). Each box represents the 25 th to 75 th percentiles, the horizontal line in each box represents the mean, and the whiskers represent the minimum and maximum values. Notice that the scale on the $y$-axis differs between panels. *Value differs significantly $(P<0.01)$ from the value for the untreated control cells. †Value differs significantly $(P<0.01)$ from the value for the IL-I $\beta$-treated control cells. al that consisted of glycosaminoglycans, as indicated by a positive response to Alcian blue stain (Figure I).

\section{Gene expression of MMP-3 and TIMP-2}

To determine the effect of TGF- $\beta$ and IL- $1 \beta$ on cartilage matrix degradation, gene expression of MMP-3 and its antagonist TIMP-2 was examined (Figure 2). For cells stimulated with IL-1 $\beta$ alone, there was a 51fold increase in MMP-3 gene expression, whereas there was a 2 -fold decrease in TIMP-2 gene expression, compared with results for cells incubated in the control medium. For cells treated with TGF- $\beta$ alone, there was a substantial decrease in expression for both genes. Gene expression of MMP-3 was significantly lower in chondrocytes exposed to TGF- $\beta$ and stimulated with IL-1 $\beta$, compared with results for cells stimulated with IL-1 $\beta$ alone. Gene expression analysis revealed a 4 -fold downregulation for $1 \mathrm{ng}$ of TGF- $\beta$ / $\mathrm{mL}$ and a 12-fold downregulation for $10 \mathrm{ng}$ of TGF- $\beta$ / $\mathrm{mL}$. In contrast, gene expression of TIMP-2 was only significantly increased after addition of $1 \mathrm{ng}$ of TGF- $\beta$ / $\mathrm{mL}$ in combination with IL-1 $\beta$. Expression of TIMP-2 in cells treated with $1 \mathrm{ng}$ of TGF- $\beta / \mathrm{mL}$ in combination with IL-1 $\beta$ was slightly upregulated, compared with the response for cells treated with IL- $1 \beta$ alone. However, $10 \mathrm{ng}$ of TGF- $\beta / \mathrm{mL}$ in combination with IL- $1 \beta$ had no significant effect on TIMP-2 gene expression.

\section{Gene expression of iNOS and NO concentration}

Gene expression of iNOS (Figure 3) and the concomitant NO concentration (Figure 4), which is an important inflammatory mediator in osteoarthritis, were determined. Cells stimulated with IL-1 $\beta$ alone had significantly higher gene expression of iNOS and a significantly higher NO concentration than did chondrocytes incubated in control medium. Gene expression of iNOS

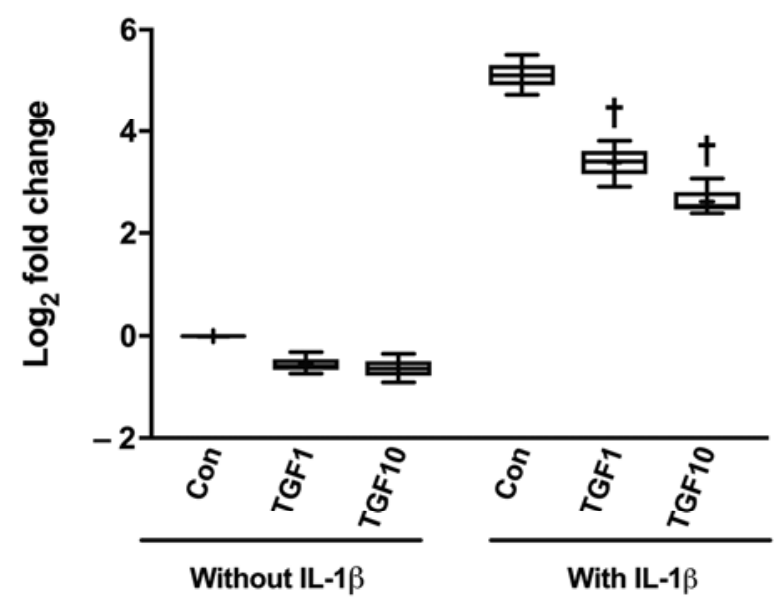

Figure 3-Box-and-whisker plot of the effects of TGF- $\beta$ on gene expression of iNOS in canine chondrocytes incubated with I and $10 \mathrm{ng}$ of TGF- $\beta / \mathrm{mL}$ for 48 hours followed by incubation with or without IL-I $\beta(10 \mathrm{ng} / \mathrm{mL})$ for 24 hours. See Figure 2 for key. 


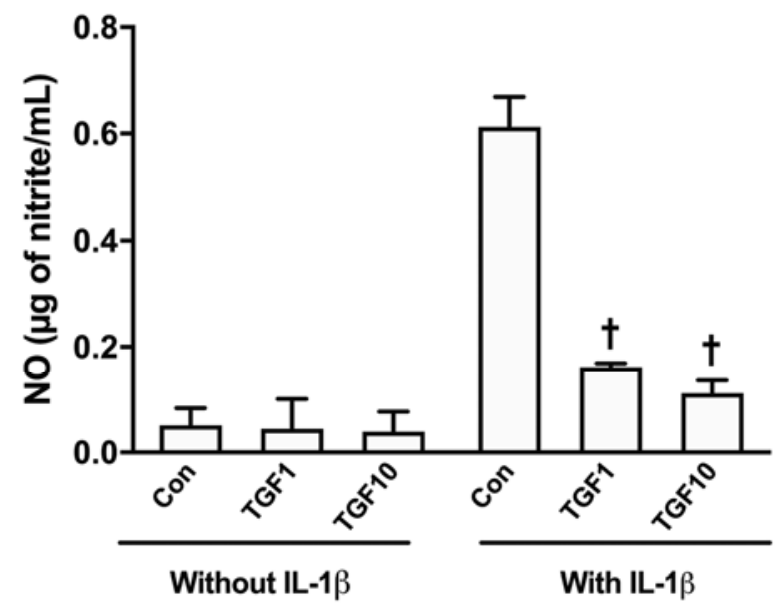

Figure 4-Mean \pm SD concentrations of $\mathrm{NO}$ in canine chondrocytes incubated with $\mathrm{I}$ and $10 \mathrm{ng}$ of TGF- $\beta / \mathrm{mL}$ for 48 hours followed by incubation with or without IL-I $\beta$ (I0 ng/ $\mathrm{mL}$ ) for 24 hours. Concentrations of NO were determined as the nitrite concentrations by use of the Griess assay. See Figure 2 for key.

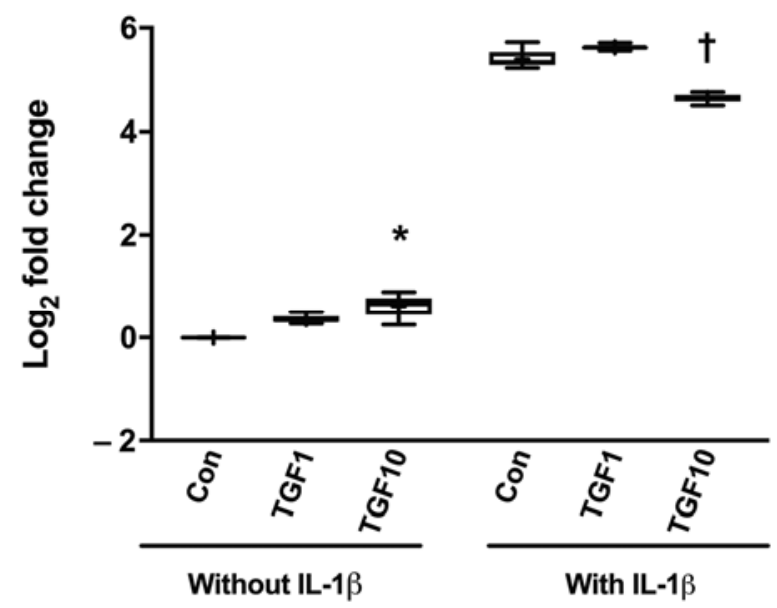

Figure 5-Box-and-whisker plot of the effects of TGF- $\beta$ on gene expression of COX-2 in canine chondrocytes incubated with I and $10 \mathrm{ng}$ of TGF- $\beta / \mathrm{mL}$ for 48 hours followed by incubation with or without IL-I $\beta(10 \mathrm{ng} / \mathrm{mL})$ for 24 hours. See Figure 2 for key.

and generation of NO were not affected by TGF- $\beta$ alone. In IL-1 $\beta$-stimulated cells treated with the 2 concentrations of TGF- $\beta$, IL-induced iNOS gene expression and NO concentration were decreased in a dose-dependent manner. There was a 3-fold downregulation of iNOS gene expression for $1 \mathrm{ng}$ of TGF- $\beta / \mathrm{mL}$ and a 6 -fold downregulation for $10 \mathrm{ng}$ of TGF- $\beta / \mathrm{mL}$, compared with results for cells treated with IL-1 $\beta$ alone.

\section{Gene expression of COX-2 and PGE concentration}

Effects on PGE, which is another important inflammatory mediator, were determined by gene expression analysis of the PGE-generating enzyme

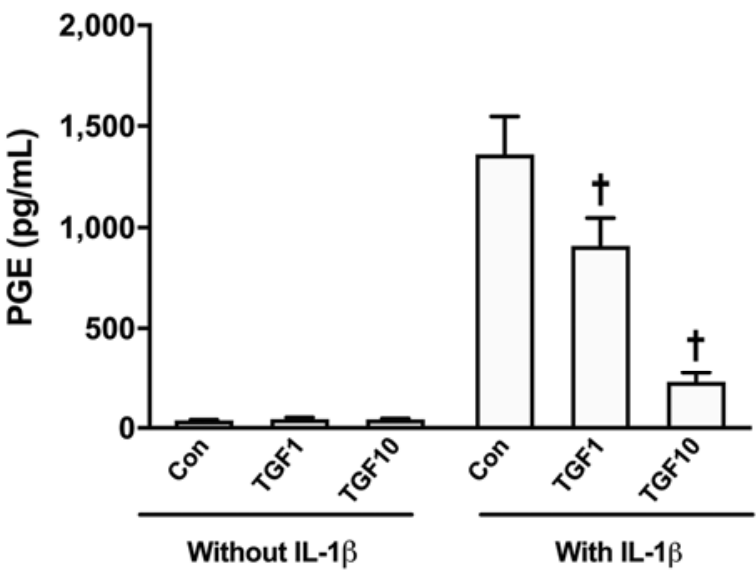

Figure 6-Mean $\pm \mathrm{SD}$ concentration of $\mathrm{PGE}$ in canine chondrocytes incubated with I and $10 \mathrm{ng}$ of TGF- $\beta / \mathrm{mL}$ for 48 hours followed by incubation with or without IL-I $\beta$ (10 ng/ $\mathrm{mL}$ ) for 24 hours. Concentrations of PGE were determined by use of an enzyme immunoassay kit. See Figure 2 for key.

COX-2 (Figure 5) and by measuring the PGE concentration (Figure 6). When cells were stimulated with IL-1 $\beta$ alone, there was a significant increase in COX-2 gene expression, which was accompanied by a high PGE concentration. For chondrocytes incubated with TGF- $\beta$ alone, no significant changes in PGE concentration were found in the cell culture supernatant. In contrast, COX-2 gene expression was approximately twice as high for cells incubated with $10 \mathrm{ng}$ of TGF- $\beta / \mathrm{mL}$. When cells were stimulated with IL-1 $\beta, 10 \mathrm{ng}$ of TGF- $\beta / \mathrm{mL}$ significantly reduced gene expression of COX-2, compared with results for cells stimulated with IL-1 $\beta$ alone. This change in gene expression was associated with significantly lower PGE concentrations in cells treated with TGF- $\beta$ in combination with IL-1 $\beta$.

\section{Discussion}

For the study reported here, we chose to use a 2-D technique, similar to the one used in another study. 5 Effects in monolayer cultures can only be attributable to cell metabolism and are not affected by surrounding 3-D structures. Additionally, all cells in a monolayer culture have the same access to cell culture media components and stimulants. A major disadvantage is that chondrocytes grown in monolayer tend to lose their phenotype and become fibroblastoid. ${ }^{39}$ However, because the cells used in the present study formed clusters encapsulated in extracellular matrix, we believed that the cell culture consisted primarily of differentiated chondrocytes.

It is known that IL-1 $\beta$ is a major trigger in osteoarthritis and stimulates catabolic changes, suppresses anabolic pathways, and decreases matrix synthesis. ${ }^{8}$ In chondrocyte culture, it is also known that IL-1 $\beta$ initiates an inflammatory cascade comparable to that 
of naturally occurring osteoarthritis. ${ }^{4-7}$ In the present study, the addition of IL- $1 \beta$ led to higher expression of all genes and concentrations of inflammatory mediators selected for analysis, compared with results for nonstimulated control cells. Analysis of data for the real-time qPCR assay revealed a $\geq 35$-fold upregulation for expression of the catabolic enzymes iNOS, COX-2, and MMP-3, whereas the matrix-protective enzyme TIMP-2 was slightly downregulated. The cells were more responsive to stimulation to induce osteoarthritic changes than has been reported for other studies on canine chondrocytes in 2-D or 3-D culture, even when higher IL-1 $\beta$ concentrations ${ }^{6,7}$ or a combination of several cytokines ${ }^{4,5}$ were used. Therefore, we concluded that the addition of $10 \mathrm{ng}$ of IL- $1 \beta / \mathrm{mL}$ for 24 hours was sufficient for canine chondrocyte cultures in monolayer to evoke a subset of events similar to those of naturally occurring osteoarthritis. The canine cell culture described here served as a simple in vitro technique to mimic osteoarthritis in dogs. This technique may be used to investigate the mechanisms underlying osteoarthritis in dogs and to explore new treatment options for this degenerative joint disease.

To our knowledge, the study reported here was the first in which in vitro evaluation of the impact of TGF- $\beta$ to mimic osteoarthritis in dogs has been described. The effects of TGF- $\beta$ on chondrocytes are rather complex. Although members of the TGF family are important for chondrocyte differentiation ${ }^{22}$ and the maintenance of healthy cartilage, ${ }^{40}$ some authors have detected a negative impact, ${ }^{28,29}$ which suggests that TGF- $\beta$ may also contribute to the pathogenesis of osteoarthritis. In the present study, we found no evidence for detrimental effects of TGF- $\beta$.

To investigate combined actions of TGF- $\beta$ and IL-1 $\beta$ on chondrocyte-specific gene expression and mediator release, both cytokines were added alone but also in combination to the cells after pretreatment with TGF- $\beta$. Different concentrations have been used to detect potential synergistic ${ }^{41,42}$ or antagonistic effects. ${ }^{24,27}$ In fact, TGF- $\beta$ in the present study could have attenuated signs of cartilage degradation induced by IL-1 $\beta$. Only a few in vivo ${ }^{43,44}$ and in vitro ${ }^{5,7}$ studies have been conducted to examine the role of MMP-3 in osteoarthritis of dogs. The MMPs degrade type II collagen, ${ }^{45}$ which is a major component of the extracellular matrix. In particular, MMP-3 is a useful marker of joint disease in dogs. ${ }^{44}$ In healthy joints, the destructive actions of MMPs are balanced by their inhibitor TIMPs, which act by blocking MMPs in a ratio of 1 to $1.46,47$ Therefore, protective actions on the extracellular matrix are mediated by a higher expression of TIMPs or a lower expression of MMPs. In the study reported here, TGF- $\beta$ alone reduced MMP-3 gene expression but decreased the expression of its inhibitor TIMP-2. However, the ratio of MMP-3 to TIMP- 2 was lower in cells treated with TGF- $\beta$, which indicated that TGF- $\beta$ alone significantly inhibited matrix degradation in healthy cartilage. When TGF- $\beta$ was applied in combination with IL-1 $\beta, 1$ ng of TGF- $\beta$ / $\mathrm{mL}$ caused an effective dose-dependent downregulation of MMP-3 gene expression that was accompanied by a slight increase in TIMP-2 gene expression. Because the ratio of MMP-3 to TIMP- 2 decreased in cells treated with TGF- $\beta$ applied in combination with IL-1 $\beta$, compared with result for IL- $1 \beta$-stimulated control cells, we concluded that TGF- $\beta$ applied in low concentrations had a protective effect on cartilage matrix. Whether expression of other members of the TIMP family would be increased or other members of the MMP family would be decreased, which therefore may have contributed to the favorable response, would need to be investigated in additional studies.

Nitric oxide exerts a number of detrimental effects on cartilage, including enhancement of matrix destruction, induction of inflammatory mediators, and apoptosis of chondrocytes. ${ }^{48,49}$ Incubation with TGF- $\beta$ followed by stimulation with IL-1 $\beta$ suppressed NO concentrations and iNOS gene expression in a dose-dependent manner. These results indicated that the strong decrease in NO concentration was, at least in part, associated with the reduction in gene expression of the NO-generating enzyme iNOS. Overall, results of the present study confirmed that TGF- $\beta$ rapidly attenuated IL- $1 \beta$-induced NO production in canine chondrocytes. In accordance with results of other studies, TGF- $\beta$ alone did not alter iNOS mRNA or NO concentrations, whereas IL-1 $\beta$ alone effectively induced iNOS gene expression and higher concentrations of NO. This pattern of responsiveness is known to be linked to highly differentiated cells ${ }^{14}$ and therefore also suggested that the cells used in the present study had many features of differentiated chondrocytes.

Depending on the concentration, PGE can exert anabolic or catabolic actions in cartilage. At higher concentrations, it is considered a major component of the pathological mechanisms that cause pain and joint inflammation, ${ }^{50}$ whereas at lower concentrations, it has been found to have protective effects on the extracellular matrix. ${ }^{51}$ Because there was no PGE assay commercially available that accurately discriminated between $\mathrm{PGE}_{2}$ and $\mathrm{PGE}_{3}$, total PGE concentration was measured in the supernatants. However, it has been found that in vivo concentrations of $\mathrm{PGE}_{3}$ are much lower in dogs than are $\mathrm{PGE}_{2}$ concentrations (ratio, approx 1 to 500). ${ }^{52}$ Therefore, we assumed that the significant changes in total PGE concentration were mainly attributable to $\mathrm{PGE}_{2}$ and not to $\mathrm{PGE}_{3}$. Analysis of the results for the present study indicated that TGF- $\beta$ reduced the IL-dependent increase in PGE concentration in a dose-dependent manner, whereas only $10 \mathrm{ng}$ of TGF- $\beta / \mathrm{mL}$ significantly decreased COX-2 gene expression. In cells exposed to TGF- $\beta$ alone, PGE concentration was not affected, whereas COX-2 mRNA was slightly more abundant. Changes in COX-2 expression often were not consistent with PGE concentration in the cell culture medium. Therefore, we assumed that COX-2 gene expression may not have 
been the predominant pathway for altering PGE concentrations in canine chondrocytes. Taken together, these results suggested that TGF- $\beta$ can decrease ILinduced PGE production, probably by allowing a shift from the deleterious effect of high concentrations of PGE to the rather chondroprotective effects at lower concentrations of PGE.

It is known that low concentrations of TGF- $\beta$ decrease the matrix-degrading activity of IL-1 $\beta^{26,27}$ and stimulate matrix synthesis. ${ }^{21}$ In contrast, higher concentrations of TGF- $\beta$ have catabolic effects on extracellular matrix, including upregulation of matrixdegrading enzymes. ${ }^{28,29}$ The diverse actions of TGF- $\beta$ could be attributed to a dose-dependent modulation of signaling pathways. ${ }^{53}$ Although the canine chondrocytes of the present study were exposed to a maximum of $10 \mathrm{ng}$ of TGF- $\beta / \mathrm{mL}$ over 72 hours, mostly beneficial effects on matrix metabolism were detected, even when used in combination with the catabolic mediator IL-1 $\beta$. It was most probable that IL-1 $\beta$ signaling was rapidly altered by TGF- $\beta$ in a dose-dependent manner. Studies ${ }^{26,54}$ on rabbit chondrocytes have revealed that TGF- $\beta$ suppresses the production of IL- $1 \beta$ by downregulating expression of the IL-1 receptor. The present study provided evidence that this may be the case for canine chondrocytes as well.

Changes in TGF- $\beta$ signaling during maturation have been assessed in murine, bovine, and human cartilage samples. ${ }^{55,56}$ Results of those studies ${ }^{55,56}$ revealed an age-related decrease in TGF- $\beta$ responsiveness and the loss of chondroprotective properties in mature cartilage. Although chondrocytes in the present study were obtained from older dogs, they were highly responsive to TGF- $\beta$. Therefore, we concluded that age-related changes were masked and TGF- $\beta$ remained effective as a protective agent in cultured canine chondrocytes.

Analysis of the results for the present study suggested that TGF- $\beta$ might be an important factor for limiting cartilage damage in dogs with osteoarthritis. Therefore, TGF- $\beta$ should be considered as a therapeutic target for osteoarthritis in dogs.

\section{Acknowledgments}

Presented in part as an abstract at the meeting of the Specialist Group for Physiology and Biochemistry of the German Veterinary Medical Society, Berlin, March 2016.

The authors thank Bastian Kaiser for assistance with the gene expression analysis.

\section{Footnotes}

a. Collagenase $\mathrm{P}$, Roche Diagnostic Deutschland $\mathrm{GmbH}$, Mannheim, Germany.

b. Collagenase CLS, Biochrom AG, Berlin, Germany

c. Sigma-Aldrich Chemie GmbH, Steinheim, Germany.

d. Life Technologies, Carlsbad, Calif.

e. Sino Biological Inc, Beijing, China.

f. InviTrap spin cell RNA mini kit, Stratec Molecular GmbH, Berlin, Germany.

g. DNAse I, RNAse-free, Thermo Scientific Inc, Waltham, Mass.

h. Nanodrop 1000, Thermo Scientific Inc, Waltham, Mass.

i. Maxima First Strand cDNA synthesis kit for RT-qPCR, Thermo Scientific Inc, Waltham, Mass. j. T1 thermocycler 96, Biometra GmbH, Göttingen, Germany.

k. KAPA Sybr Fast qPCR kit master mix universal, Kapa Biosystem Ltd, Cape Town, Republic of South Africa.

1. RotorGene 6000, Qiagen GmbH, Hilden, Germany.

m. Relative expression software tool, version 2.013, Qiagen GmbH, Hilden, Germany.

n. SpectraMax 340 PC, Molecular Device, Munich, Germany.

o. Carl Roth GmbH + Co KG, Karlsruhe, Germany.

p. Prostaglandin E2 enzyme immunoassay kit, Arbor Assay, Ann Arbor, Mich.

q. Victor2 1420 multilabel counter, PerkinElmer, Waltham, Mass.

r. GraphPad Prism 4 software, GraphPad Software Inc, La Jolla, Calif.

\section{References}

1. Pfander, D. Physiologie und Pathophysiologie des Gelenkknorpels Akt Rbeumatol 2005;30:344-353.

2. Houard X, Goldring MB, Berenbaum F. Homeostatic mechanisms in articular cartilage and role of inflammation in osteoarthritis. Curr Rbeumatol Rep 2013;15:375-385.

3. Johnston SA. Osteoarthritis. Joint anatomy, physiology, and pathobiology. Vet Clin North Am Small Anim Pract 1997;27:699-723.

4. Dycus DL, Au AY, Grzanna MW, et al. Modulation of inflam mation and oxidative stress in canine chondrocytes. $A m J$ Vet Res 2013;74:983-989.

5. Rai MF, Rachakonda PS, Manning K, et al. Quantification of cytokines and inflammatory mediators in a three-dimensional model of inflammatory arthritis. Cytokine 2008;42:8-17.

6. Kuroki K, Stoker AM, Cook JL. Effects of proinflammatory cytokines on canine articular chondrocytes in a threedimensional culture. Am J Vet Res 2005;66:1187-1196.

7. Cook JL, Anderson CC, Kreeger JM, et al. Effects of human recombinant interleukin-1 beta on canine articular chondrocytes in three-dimensional culture. Am J Vet Res 2000;61:766-770.

8. Wojdasiewicz P, Poniatowski ŁA, Szukiewicz D. The role of inflammatory and anti-inflammatory cytokines in the pathogenesis of osteoarthritis. Mediators Inflamm 2014;2014:561459.

9. Cortial D, Gouttenoire J, Rousseau CF, et al. Activation by IL-1 of bovine articular chondrocytes in culture within a 3-D collagen-based scaffold. An in vitro model to address the effect of compounds with therapeutic potential in osteoarthritis. Osteoarthritis Cartilage 2006;14:631-640.

10. Fan Z, Bau B, Yang H, et al. Freshly isolated osteoarthritic chondrocytes are catabolically more active than normal chondrocytes, but less responsive to catabolic stimulation with interleukin-1beta. Artbritis Rbeum 2005;52:136-143.

11. Kobayashi M, Squires GR, Mousa A, et al. Role of interleukin-1 and tumor necrosis factor alpha in matrix degradation of human osteoarthritic cartilage. Artbritis Rheum 2005;52:128-135.

12. Attur MG, Patel IR, Patel RN, et al. Autocrine production of IL-1 beta by human osteoarthritis-affected cartilage and differential regulation of endogenous nitric oxide, IL-6, prostaglandin E2, and IL-8. Proc Assoc Am Pbysicians 1998;110:65-72.

13. Pelletier JP, Mineau F, Ranger $P$, et al. The increased synthesis of inducible nitric oxide inhibits IL-1ra synthesis by human articular chondrocytes: possible role in osteoarthritic cartilage degradation. Osteoarthritis Cartilage 1996;4:77-84.

14. Blanco FJ, Geng Y, Lotz M. Differentiation-dependent effects of IL-1 and TGF-beta on human articular chondrocyte proliferation are related to inducible nitric oxide synthase expression. J Immunol 1995;154:4018-4026.

15. Pfander D, Heinz N, Rothe P, et al. Tenascin and aggrecan expression by articular chondrocytes is influenced by interleukin 1beta: a possible explanation for the changes in matrix synthesis during osteoarthritis. Ann Rbeum Dis 2004;63:240-244.

16. Goldring MB, Birkhead J, Sandell LJ, et al. Interleukin 1 suppresses expression of cartilage-specific types II and IX col- 
lagens and increases types I and III collagens in human chondrocytes. J Clin Invest 1988;82:2026-2037.

17. Aigner T, Fundel K, Saas J, et al. Large-scale gene expression profiling reveals major pathogenetic pathways of cartilage degeneration in osteoarthritis. Artbritis Rbeum 2006;54:3533-3544.

18. Yuan GH, Masuko-Hongo $\mathrm{K}$, Sakata $\mathrm{M}$, et al. The role of $\mathrm{C}-\mathrm{C}$ chemokines and their receptors in osteoarthritis. Arthritis Rbeum 2001;44:1056-1070.

19. Cicione C, Muiños-Lopéz E, Hermida-Gómez T, et al. Alternative protocols to induce chondrogenic differentiation: transforming growth factor-beta superfamily. Cell Tissue Bank 2015;16:195-207.

20. Csaki C, Matis U, Mobasheri A, et al. Chondrogenesis, osteogenesis and adipogenesis of canine mesenchymal stem cells: a biochemical, morphological and ultrastructural study. Histochem Cell Biol 2007;128:507-520.

21. Demoor-Fossard M, Boittin M, Redini F, et al. Differential effects of interleukin-1 and transforming growth factor beta on the synthesis of small proteoglycans by rabbit articular chondrocytes cultured in alginate beads as compared to monolayers. Mol Cell Biochem 1999;199:69-80.

22. Hunziker EB, Driesang IM, Morris EA. Chondrogenesis in cartilage repair is induced by members of the transforming growth factor-beta superfamily. Clin Orthop Relat Res 2001;391:S171-S181.

23. Ikegawa N, Sasho $\mathrm{T}$, Yamaguchi $\mathrm{S}$, et al. Identification of genes required for the spontaneous repair of partial-thickness cartilage defects in immature rats. Connect Tissue Res 2016;57:190-199.

24. Vuolteenaho K, Moilanen T, Jalonen U, et al. TGF beta inhibits IL-1-induced iNOS expression and NO production in immortalized chondrocytes. Inflamm Res 2005;54:420-427.

25. Su S, Dehnade F, Zafarullah M. Regulation of tissue inhibitor of metalloproteinases-3 gene expression by transforming growth factor-beta and dexamethasone in bovine and human articular chondrocytes. DNA Cell Biol 1996;15:1039-1048.

26. Harvey AK, Hrubey PS, Chandrasekhar S. Transforming growth factor-beta inhibition of interleukin-1 activity involves down-regulation of interleukin-1 receptors on chondrocytes. Exp Cell Res 1991;195:376-385.

27. Pujol JP, Galera P, Redini F, et al. Role of cytokines in osteoarthritis: comparative effects of interleukin 1 and transforming growth factor-beta on cultured rabbit articular chondrocytes. J Rbeumatol Suppl 1991;27:76-79.

28. Moulharat N, Lesur C, Thomas M, et al. Effects of transforming growth factor-beta on aggrecanase production and proteoglycan degradation by human chondrocytes in vitro. Osteoarthritis Cartilage 2004;12:296-305.

29. Moldovan F, Pelletier JP, Hambor J, et al. Collagenase-3 (matrix metalloprotease 13) is preferentially localized in the deep layer of human arthritic cartilage in situ: in vitro mimicking effect by transforming growth factor beta. Arthritis Rbeum 1997;40:1653-1661.

30. Scharstuhl A, Glansbeek HL, van Beuningen HM, et al. Inhibition of endogenous TGF-beta during experimental osteoarthritis prevents osteophyte formation and impairs cartilage repair. J Immunol 2002;169:507-514.

31. van Beuningen HM, Glansbeek HL, van der Kraan PM, et al Osteoarthritis-like changes in the murine knee joint resulting from intra-articular transforming growth factor-beta injections. Osteoarthritis Cartilage 2000;8:25-33.

32. Lee M-C, Ha C-W, Elmallah RK, et al. A placebo-controlled randomised trial to assess the effect of TGF-beta 1-expressing chondrocytes in patients with arthritis of the knee. Bone Joint J 2015;97-B:924-932.

33. Kaps C, Fuchs S, Endres M, et al. Molekulare Charakterisierung von gezüchteten humanen dreidimensionalen Chondrozytentransplantaten. Orthopade 2004;33:76-85.

34. Kuroki K, Cook JL, Stoker AM, et al. Characterizing osteochondrosis in the dog: potential roles for matrix metalloproteinases and mechanical load in pathogenesis and disease progression. Osteoarthritis Cartilage 2005;13:225-234.
35. Aupperle H, Thielebein J, Kiefer B, et al. Expression of genes encoding matrix metalloproteinases (MMPs) and their tissue inhibitors (TIMPs) in normal and diseased canine mitral valves. J Comp Pathol 2009;140:271-277.

36. Morchón R, López-Belmonte J, Bazzocchi C, et al. Dogs with patent Dirofilaria immitis infection have higher expression of circulating $\mathrm{IL}-4, \mathrm{IL}-10$ and iNOS mRNA than those with occult infection. Vet Immunol Immunopathol 2007;115:184-188.

37. Peters IR, Peeters D, Helps CR, et al. Development and application of multiple internal reference (housekeeper) gene assays for accurate normalisation of canine gene expression studies. Vet Immunol Immunopathol 2007;117:55-66.

38. NG KW, Lima EG, Liming B, et al. Passaged adult chondrocytes can form engineered cartilage with functional mechanical properties: a canine model. Tissue Eng Part A 2010;16:1041-1051.

39. Rai MF, Rachakonda PS, Manning $\mathrm{K}$, et al. Molecular and phenotypic modulations of primary and immortalized canine chondrocytes in different culture systems. Res Vet Sci 2009;87:399-407.

40. Shen J, Li J, Wang B, et al. Deletion of the transforming growth factor beta receptor type II gene in articular chondrocytes leads to a progressive osteoarthritis-like phenotype in mice. Arthritis Rbeum 2013;65:3107-3119.

41. Mejiers MH, Aisa CM, Billingham ME, et al. The effect of interleukin-1 beta and transforming growth factor beta on cathepsin B acitivity in human articular. Agents Actions 1994;41:C198-C200.

42. Fawthrop FW, Frazer A, Russell RG, et al. Effects of transforming growth factor beta on the production of prostaglandin $\mathrm{E}$ and caseinase activity of unstimulated and interleukin 1-stimulated human articular chondrocytes in culture. $\mathrm{Br} \mathrm{J}$ Rheumatol 1997:36:729-734.

43. Fujita Y, Hara Y, Nezu Y, et al. Direct and indirect markers of cartilage metabolism in synovial fluid obtained from dogs with hip dysplasia and correlation with clinical and radiographic variables. Am J Vet Res 2005;66:2028-2033.

44. Hegemann N, Kohn B, Brunnberg L, et al. Biomarkers of joint tissue metabolism in canine osteoarthritic and arthritic joint disorders. Osteoarthritis Cartilage 2002;10:714-721.

45. Murphy G, Lee M. What are the roles of metalloproteinases in cartilage and bone damage? Ann Rheum Dis 2005;64(suppl 4):iv44-iv47.

46. Bee A, Barnes A, Jones MD, et al. Canine TIMP-2: purification, characterization and molecular detection. Vet $J$ 2000;160:126-134.

47. Gomis-Rüth FX, Maskos K, Betz M, et al. Mechanism of inhibition of the human matrix metalloproteinase stromelysin-1 by TIMP-1. Nature 1997:389:77-81.

48. Ridnour LA, Windhausen AN, Isenberg JS, et al. Nitric oxide regulates matrix metalloproteinase- 9 activity by guanylylcyclase-dependent and -independent pathways. Proc Natl Acad Sci U S A 2007;104:16898-16903.

49. Whiteman M, Armstrong JS, Cheung NS, et al. Peroxynitrite mediates calcium-dependent mitochondrial dysfunction and cell death via activation of calpains. FASEB J 2004;18:13951397.

50. Attur M, Al-Mussawir HE, Patel J, et al. Prostaglandin E2 exerts catabolic effects in osteoarthritis cartilage: evidence for signaling via the EP4 receptor. J Immunol 2008;181:5082-5088.

51. Tchetina EV, Di Battista JA, Zukor DJ, et al. Prostaglandin PGE(2) at very low concentrations suppresses collagen cleavage in cultured human osteoarthritic articular cartilage: this involves a decrease in expression of proinflammatory genes, collagenases and COL10A1, a gene linked to chondrocyte hypertrophy. Arthritis Res Ther 2007;9:R75.

52. Kearns RJ, Hayek MG, Turek JJ, et al. Effect of age, breed and dietary omega-6 (n-6): omega-3 (n-3) fatty acid ratio on immune function, eicosanoid production, and lipid peroxidation in young and aged dogs. Vet Immunol Immunopathol 1999;69:165-183.

53. Baugé $\mathrm{C}$, Legendre $\mathrm{F}$, Leclercq $\mathrm{S}$, et al. Interleukin-1beta impairment of transforming growth factor beta1 signaling 
by down-regulation of transforming growth factor beta receptor type II and up-regulation of $\mathrm{Smad} 7$ in human articular chondrocytes. Artbritis Rheum 2007;56:3020-3032.

54. Rédini F, Mauviel A, Pronost S, et al. Transforming growth factor beta exerts opposite effects from interleukin-1 beta on cultured rabbit articular chondrocytes through reduction of interleukin-1 receptor expression. Arthritis Rheum 1993;36:44-50.
55. van der Kraan PM. Age-related alterations in TGF beta signaling as a causal factor of cartilage degeneration in osteoarthritis. Biomed Mater Eng 2014;24(suppl):75-80.

56. Blaney Davidson EN, Scharstuhl A, Vitters EL, et al. Reduced transforming growth factor-beta signaling in cartilage of old mice: role in impaired repair capacity. Artbritis Res Ther 2005;7:R1338-R1347.

\section{Appendix}

Oligonucleotide primers used for real-time QPCR assays performed to analyze changes in gene expression in canine chondrocytes treated with IL-I $\beta$, TGF- $\beta$, or a combination of both.

\begin{tabular}{|c|c|c|c|c|c|}
\hline Gene & Accession No. & Primer sequence $\left(5^{\prime}-3^{\prime}\right)$ & $\begin{array}{c}\text { Amplicon } \\
\text { size (bp) }\end{array}$ & $\begin{array}{l}\text { TA } \\
\left({ }^{\circ} \mathrm{C}\right)\end{array}$ & Reference \\
\hline MMP-3 & NM_001002967 & $\begin{array}{l}\text { F ATGGCATCCAGTCCCTGTAT } \\
\text { R AAAGAACAGGAACTCTCCCC }\end{array}$ & 161 & 53 & 34 \\
\hline TIMP-2 & NM_001003082.1 & $\begin{array}{l}\text { F CAACGCGGACGTAGTGATTA } \\
\text { R TTCCCGCAATGAGATACTCC }\end{array}$ & 227 & 53 & 35 \\
\hline COX-2 & NM_00I003354 & $\begin{array}{l}\text { F GCCTTACCCAGTTTGTGGAA } \\
\text { R AGCCTAAAGCGTTTGCGATA }\end{array}$ & 163 & 52 & 31 \\
\hline iNOS & XM_005624846.I & $\begin{array}{l}\text { F CTTCAACCCCAAGGTTGTCTGCAT } \\
\text { R ATGTCATGAGCAAAGGCGCAGAAC }\end{array}$ & 231 & 60 & 36 \\
\hline TBP & XM_849432.2 & $\begin{array}{l}\text { F CTATTTCTTGGTGTGCATGAGG } \\
\text { R CCTCGGCATTCAGTCTTTTC }\end{array}$ & 96 & 55 & 37 \\
\hline GAPDH & NM_001003|42.I & $\begin{array}{l}\text { F GTGACTTCAACAGTGACACC } \\
\text { R CCTTGGAGGCCATGTAGACC }\end{array}$ & 153 & 52 & 38 \\
\hline
\end{tabular}

Target genes were normalized to expression of the reference genes TBP and GAPDH.

$\mathrm{F}=$ Forward. $\mathrm{R}=$ Reverse. $\mathrm{TA}=$ Annealing temperature. 


\subsection{Publikation 2}

Polyunsaturated fatty acids influence inflammatory markers in a cellular model for canine osteoarthritis

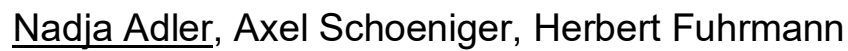

Publiziert im: Journal of Animal Physiology and Animal Nutrition 2017; 102(2): e623-e632.

Doi: 10.1111/jpn.12804

\section{Eigenanteile der einzelnen Autoren}

$\underline{\text { Nadja Adler }}$

$\diamond$ Gewinnung der Daten

$\diamond \quad$ Analyse der Daten

$\diamond$ Interpretation der Daten

$\diamond$ Zusammenstellung der Publikation

\section{$\underline{\text { Axel Schoeniger }}$}

$\diamond \quad$ Analyse der Daten

$\diamond$ Interpretation der Daten

$\diamond$ Durchsicht und Korrektur der Publikation

\section{$\underline{\text { Herbert Fuhrmann }}$}

$\diamond \quad$ Zielstellung und Aufbau der Studie

$\diamond$ Interpretation der Daten

$\diamond$ Durchsicht und Korrektur der Publikation 


\title{
Polyunsaturated fatty acids influence inflammatory markers in a cellular model for canine osteoarthritis
}

\author{
\begin{tabular}{l|l|l} 
N. Adler & A. Schoeniger & H. Fuhrmann (B)
\end{tabular}
}

Institute of Biochemistry, Faculty of Veterinary Medicine, University of Leipzig, Leipzig, Germany

\section{Correspondence}

H. Fuhrmann, Institute of Biochemistry, Faculty of Veterinary Medicine, University of Leipzig, Leipzig, Germany.

Email: fuhrmann@vetmed.uni-leipzig.de

\section{Funding information}

Boehringer Ingelheim Animal Health $\mathrm{GmbH}$, Ingelheim am Rhein, Germany

\begin{abstract}
Summary
Although it is well recognized that dietary supplementation with fish oil improves clinical symptoms in dogs suffering from osteoarthritis, the molecular basis for the dietary benefit is not yet completely resolved in dogs. This study was designed to further clarify how polyunsaturated fatty acids (PUFA) affect key factors of cartilage degeneration in a canine cell culture system mimicking osteoarthritis. Canine chondrocytes were incubated either without or with $10 \mu \mathrm{M}$ of eicosapentaenoic acid (EPA), docosahexaenoic acid (DHA), arachidonic acid (AA) or $3.6 \mu \mathrm{M}$ ibuprofen (Ibu) as positive control for 6 days. After the supplementation, cells were stimulated with $10 \mathrm{ng} / \mathrm{ml}$ interleukin-1 $\beta$ (IL-1 $\beta$ ) for another $48 \mathrm{hr}$ to induce osteoarthritic changes, or left unstimulated. We analysed fatty acid uptake via gas-liquid chromatography, nitric oxide (NO) production via Griess assay, prostaglandin E (PGE) production via ELISA and relative gene expression of several cartilage matrix proteinases, inducible nitric oxide synthase (iNOS) and cyclooxygenase-2 via RT-qPCR. After supplementation, the chondrocytes rapidly incorporated the PUFA into their fatty acid pools. The stimulation with IL-1 $\beta$ caused a marked increase of most of the inflammatory markers measured. N-3 PUFA EPA reduced IL-induced gene expression of iNOS and corresponding production of NO. N-6 PUFA AA also decreased iNOS and NO, but furthermore lowered gene expression of matrix metalloproteinase-3. On the other hand, AA upregulated the aggrecanase ADAMTS- 5 and augmented the release of PGE. The effect of n-3 PUFA DHA turned out to be negligible. Our results reveal molecular mechanisms by which PUFA affect degenerative joint disease in dogs. Of particular importance is that not only EPA but also AA decreased several inflammatory markers in our model. Thus, we conclude that an appropriate balance of both n-3 and n- 6 fatty acids deserves more attention in dietary interventions.
\end{abstract}

\section{KEYWORDS}

arachidonic acid, canine chondrocytes, docosahexaenoic acid, eicosapentaenoic acid, interleukin-1 $\beta$

\section{1 | INTRODUCTION}

Osteoarthritis (OA) has been estimated to affect one in five dogs over 1 year of age in the United States (Johnston, 1997). It is a progressive degenerative disease that mostly occurs after acquired or congenital joint disorders such as canine hip dysplasia, patellar luxation or cruciate ligament injury (Henrotin, Sanchez, \& Balligand, 2005). Affected animals suffer from joint pain, swelling, restricted mobility and therefore, a reduced quality of life (Johnston, 1997). 
In healthy cartilage, the integrity of tissue is maintained by a balance of catabolic and anabolic processes. In OA, an overproduction of pro-inflammatory cytokines like interleukin-1 $\beta$ (IL-1 $\beta$ ) leads to the degeneration of cartilage (Wojdasiewicz, Poniatowski, \& Szukiewicz, 2014). The loss of cartilage matrix involves two families of enzymes: the disintegrin and metalloproteinases with thrombospondin motif enzymes (ADAMTSs, e.g., ADAMTS-5) are responsible for the early cleavage of aggrecan (Murphy \& Lee, 2005; Tortorella, Malfait, Deccico, \& Arner, 2001) while the matrix metalloproteinases (MMPs, such as MMP-13, MMP-3) degrade the remaining matrix by the removal of collagen (Murphy \& Lee, 2005; Poole et al., 2003). Both families are suppressed by binding to the tissue inhibitors of metalloproteinases (TIMPs, such as TIMP-2) in a ratio of 1:1 (Bee et al., 2000; Gomis-Ruth et al., 1997). It has been shown that some members of the TIMP family are significantly downregulated in canine OA (Clements, Fitzpatrick, Carter, \& Day, 2009). In addition, the release of inflammatory mediators such as nitric oxide (NO) and prostaglandin E (PGE) triggers chronic inflammation and chondrocyte apoptosis (Amin et al., 1997; Attur et al., 2008). The progressive imbalance of catabolic and anabolic activities eventually leads to extensive breakdown of cartilage (Houard, Goldring, \& Berenbaum, 2013).

Management of OA is often limited to palliative measures to decrease pain and slow disease progression, given that curative treatments have not yet been identified. In clinical practice, non-steroidal anti-inflammatory drugs (NSAIDs) are first choice for long-term OA treatment (Bound, Upjohn, Jackson, \& Baines, 2011). As these pharmaceuticals are known to have harmful side effects (Monteiro-Steagall, Steagall, \& Lascelles, 2013), there is an urgent need for new treatment strategies to manage canine OA.

Several feeding studies (Fritsch et al., 2010; Mehler, May, King, Harris, \& Shah, 2016; Moreau et al., 2013; Roush et al., 2010) have suggested that dietary supplementation with marine $n-3$ fatty acids is beneficial in the treatment of canine OA. Two classes of essential polyunsaturated fatty acids (PUFA) are important as part of a healthy dog diet: the $n-6$ fatty acids, for example, arachidonic acid (AA), which are present in meat and vegetable oils, and the n-3 fatty acids, for example, eicosapentaenoic acid (EPA) and docosahexaenoic acid (DHA), which both are found predominantly in marine feed. While AA is a major precursor of pro-inflammatory eicosanoids, EPA and DHA are converted to eicosanoids which are less or even antiinflammatory and may therefore protect from chronic inflammation (Hurst, Rees, Randerson, Caterson, \& Harwood, 2009). However, in vitro studies investigating the underlying mechanisms associated with dietary intake of fatty acids in canine OA have not been reported so far.

In this study, a cell culture model of chondrocytes stimulated with $\mathrm{IL}-1 \beta$ was used to mimic cartilage degradation in canine OA. After enrichment of the chondrocytes with DHA, EPA or AA, the expression and activity of several inflammatory markers were investigated. We hypothesize that supplementation with $n-3$ fatty acids, in contrast to $n-6$ fatty acids, promotes an anti-inflammatory response in canine chondrocytes.

\section{MATERIALS AND METHODS}

\section{1 | Materials}

Dulbecco's Modified Eagle Medium (DMEM) with high glucose and without Phenol Red was obtained from Genaxxon (Ulm, Germany). Collagenase $P$ was purchased from Roche Diagnostics (Basel, Switzerland), and collagenase CLS, foetal bovine serum superior (FBS), trypsin-EDTA and penicillin/streptomycin $(10,000 \mathrm{U} / \mathrm{ml} / 10,000 \mu \mathrm{g} /$ $\mathrm{ml}$ ) were purchased from Biochrome (Berlin, Germany). Other chemicals for chondrocyte isolation and cryopreservation were obtained from Sigma-Aldrich (St. Louis, MO, USA) unless noted otherwise. Chemicals and kits for real-time quantification were purchased from Thermo Fisher Scientific (Waltham, MA, USA) unless stated otherwise.

\section{2 | Chondrocyte isolation and cryopreservation}

Chondrocytes were collected from six dogs from private veterinary hospitals (medium age 11 years, euthanasia performed for reasons unrelated to this study) within $24 \mathrm{hr}$ after death. Chondrocytes were harvested according to the protocol described previously (Kaps et al., 2004) with slight modifications.

Full-thickness cartilage slices were obtained aseptically from macroscopically normal knee joints and digested in DMEM containing $1 \mathrm{U} /$ $\mathrm{ml}$ collagenase $\mathrm{P}, 330 \mathrm{U} / \mathrm{ml}$ collagenase $\mathrm{CLS}$ II, $30 \mathrm{U} / \mathrm{ml}$ hyaluronidase, $10 \%$ FBS (heat-inactivated) and $1 \%$ penicillin/streptomycin at $37^{\circ} \mathrm{C}$ with slow mixing. After incubation for $18 \mathrm{hr}$, the supernatant containing released chondrocytes was filtered through a sterile $100-\mu$ m nylon mesh, centrifuged at $400 \mathrm{~g}$ for $20 \mathrm{~min}$ and washed twice in PBS. The cells were seeded in cell culture flasks at a density of $2 \times 10^{4}$ cells/ $\mathrm{cm}^{2}$ and cultured in basic medium at $37^{\circ} \mathrm{C}, 5 \% \mathrm{CO}_{2}$ and $95 \%$ humidity until confluency (passage 0 ). The basic medium contained DMEM with $10 \%$ FBS (heat-inactivated), $1 \%$ penicillin/streptomycin, $10 \mathrm{ng} / \mathrm{ml}$ human recombinant insulin and $50 \mu \mathrm{g} / \mathrm{ml} 2$-phospho-L-ascorbic acid trisodium salt and was replaced every 2 days. Upon confluency, cells were trypsinized $(0.05 \%$ trypsin-EDTA) and washed once in PBS. Total cell numbers were determined, and the cells were frozen in DMEM with $10 \% \mathrm{FCS}$ and $5 \%$ DMSO (Roth, Karlsruhe, Germany) at $-80^{\circ} \mathrm{C}$.

\section{3 | Experimental cultures}

Eicosapentaenoic acid (EPA; C20:5n3), docosahexaenoic acid (DHA; C22:6n3) and arachidonic acid (AA; C20:4n6) (all Biotrend, Köln, Germany) were diluted in $98 \%$ ethanol and stored at $-20^{\circ} \mathrm{C}$. Fatty acids were freshly added to the culture medium at a final concentration of $10 \mu \mathrm{m}$. Final concentration of ethanol was $0.2 \% \mathrm{v} / \mathrm{v}$. In separate experiments, the fatty acid uptake by the chondrocytes was analysed to determine the optimal fatty acid concentration. For this, cells were incubated with $0,10,20$ or $50 \mu \mathrm{M}$ AA, EPA or DHA for 4,6 or 8 days. Fatty acid content of the cells was determined by gas-liquid chromatography (Fuhrmann, Zimmermann, Gück, \& Oechtering, 2006).

To provide better comparability, the NSAID ibuprofen (Life Technologies, Darmstadt, Germany) diluted in ethanol was used as 
TABLE 1 Sequences and characteristics of the primers for glycerinaldehyde 3-phosphate dehydrogenase (GAPDH), TATA-binding protein (TBP), matrix metalloproteinase-3 (MMP-3), matrix metalloproteinase-13 (MMP-13), a disintegrin and metalloproteinase with thrombospondin motif enzyme- 5 (ADAMTS-5), tissue inhibitor of metalloproteinase-2 (TIMP-2), cyclooxygenase-2 (COX-2) and inducible nitric oxide synthase (iNOS)

\begin{tabular}{|c|c|c|c|c|}
\hline \multicolumn{2}{|l|}{ Gene } & \multicolumn{2}{|c|}{ Primer sequence $\left(5^{\prime}-3^{\prime}\right)$} & \multirow{2}{*}{$\begin{array}{l}\mathrm{T}_{\mathrm{A}}\left({ }^{\circ} \mathrm{C}\right)^{\mathrm{a}} \\
52\end{array}$} \\
\hline \multirow[t]{2}{*}{ GAPDH } & \multirow[t]{2}{*}{ (Kenneth et al., 2010) } & $\mathrm{F}:$ & GTGACTTCAACAGTGACACC & \\
\hline & & $\mathrm{R}:$ & CCTTGGAGGCCATGTAGACC & \\
\hline \multirow[t]{2}{*}{ TBP } & \multirow{2}{*}{$\begin{array}{l}\text { (Peters, Peeters, } \\
\text { Helps, \& Day, 2007) }\end{array}$} & $\mathrm{F}:$ & CTATTTCTTGGTGTGCATGAGG & \multirow[t]{2}{*}{55} \\
\hline & & $\mathrm{R}:$ & CCTCGGCATTCAGTCTTTTC & \\
\hline \multirow[t]{2}{*}{ MMP-3 } & \multirow{2}{*}{$\begin{array}{l}\text { (Kuroki, Cook et al., } \\
\text { 2005) }\end{array}$} & $\mathrm{F}:$ & ATGGCATCCAGTCCCTGTAT & \multirow[t]{2}{*}{53} \\
\hline & & $\mathrm{R}:$ & AAAGAACAGGAACTCTCCCC & \\
\hline \multirow[t]{2}{*}{ MMP-13 } & \multirow{2}{*}{$\begin{array}{l}\text { (Designed by Ole } \\
\text { Lamp) }\end{array}$} & $\mathrm{F}:$ & TTCTGGCTCATGCTTTTCCT & \multirow[t]{2}{*}{52} \\
\hline & & $\mathrm{R}:$ & GCCCGTGTAGGTGTAGATGG & \\
\hline \multirow[t]{2}{*}{ ADAMTS-5 } & \multirow[t]{2}{*}{ (Moreau et al., 2006) } & $\mathrm{F}:$ & GTCGGGACCATATGTTCTC & \multirow[t]{2}{*}{52} \\
\hline & & $\mathrm{R}:$ & TGATGGTGGCTGAAGTACAC & \\
\hline \multirow[t]{2}{*}{ TIMP-2 } & \multirow[t]{2}{*}{ (Aupperle et al., 2009) } & $\mathrm{F}:$ & CAACGCGGACGTAGTGATTA & \multirow[t]{2}{*}{53} \\
\hline & & $\mathrm{R}:$ & TTCCCGCAATGAGATACTCC & \\
\hline \multirow[t]{2}{*}{$\operatorname{cox}-2$} & \multirow[t]{2}{*}{ (Rai et al., 2008) } & $\mathrm{F}:$ & GCCTTACCCAGTTTGTGGAA & \multirow[t]{2}{*}{52} \\
\hline & & $\mathrm{R}:$ & AGCCTAAAGCGTTTGCGATA & \\
\hline \multirow[t]{2}{*}{ iNOS } & \multirow[t]{2}{*}{ (Morchón et al., 2007) } & $\mathrm{F}:$ & CTTCAACCCCAAGGTTGTCTGCAT & \multirow[t]{2}{*}{60} \\
\hline & & $\mathrm{R}:$ & ATGTCATGAGCAAAGGCGCAGAAC & \\
\hline
\end{tabular}

${ }^{\mathrm{a}} \mathrm{T}_{\mathrm{A}}$, annealing temperature. a positive control. Ibuprofen (Ibu) at a final concentration of $3.6 \mu \mathrm{M}$ caused a 50\% reduction in PGE production in our cell culture model (results not shown).

Canine IL-1 1 (Life Technologies, Carlsbad, CA, USA) was reconstituted in sterile distilled water to a concentration of $50 \mu \mathrm{g} / \mathrm{ml}$, frozen in aliquots and diluted in culture medium to a concentration of $10 \mathrm{ng} / \mathrm{ml}$ immediately before use.

Thawed cells (passage 1 ) were seeded in six-well plates at a density of $1.8 \times 10^{5}$ cells/well and cultured for 6 days in basic medium containing $5 \% \mathrm{FBS}$, in the absence (control cells) or presence of $10 \mu \mathrm{m}$ EPA, DHA or AA or $3.6 \mu \mathrm{m} \mathrm{Ibu}$. The medium was changed every 2 days. After 6 days of cultivation, cells were stimulated with IL-1 $\beta$ for another $48 \mathrm{hr}$ in medium supplemented as described above. Supernatants were collected and divided into two portions. One portion was immediately assayed for NO, and the other was stored at $-80^{\circ} \mathrm{C}$ to determine PGE. Cells from monolayer cultures were trypsinized, pelleted and stored at $-80^{\circ} \mathrm{C}$ for gene expression analysis. The total yield of chondrocytes was $2 \times 10^{6}$ cells/well.

\section{4 | Gene expression analysis}

Total RNA was extracted from cells using the InviTrap Spin Cell RNA Mini Kit (Stratec, Birkenfeld, Germany) according to the manufacturer's instructions. Purity and concentration were determined spectrophotometrically (NanoDrop1000). After removal of contaminating genomic DNA by DNase treatment (DNAse I), reverse transcription was performed using the Maxima First Strand cDNA Synthesis Kit according to the manufacturer's protocol. The resulting complementary DNA was diluted $1: 10$ in water and stored at $-20^{\circ} \mathrm{C}$. Relative gene expression was determined by real-time PCR using KAPA Sybr Fast Universal qPCR Kit (Peqlab, Erlangen, Germany) following the supplier's protocol. For each primer set and every run, appropriate controls (no reverse transcriptase and no template) were included and a melting curve analysis was performed. Thermal cycling was performed in a RotorGene 6000 thermal cycler (Qiagen $\mathrm{GmbH}$, Hilden, Germany) using the following conditions: initial denaturation at $95^{\circ} \mathrm{C}$ for $3 \mathrm{~min}$ followed by 40 cycles of denaturation at $95^{\circ} \mathrm{C}$ for $3 \mathrm{~s}$, annealing at primer-specific temperatures for $20 \mathrm{~s}$ and extension at $72^{\circ} \mathrm{C}$ for $1 \mathrm{~s}$. The target gene expression was normalized to the expression of the reference genes TATA-binding protein (TBP) and glycerinaldehyde 3-phosphate dehydrogenase (GAPDH) using REST (Relative Expression Software Tool; Qiagen, Hilden, Germany). Sequences of the primers used, along with annealing temperatures, are listed in Table 1.

\subsection{Quantification of NO release}

Concentration of nitrite, a stable end product of NO, was measured by Griess assay using sodium nitrite as a standard. Briefly, $50 \mu$ of Griess reagent $(0.1 \%$ sulphanilamide in $5 \%$ phosphoric acid and $0.1 \% \mathrm{~N}$ naphthyl-ethylenediamine dihydrochloride in a ratio of $1: 1$ ) was added to $50 \mu \mathrm{l}$ of the cell culture supernatant. After $10 \mathrm{~min}$ of incubation, absorbance was read at $540 \mathrm{~nm}$ on a SpectraMax 340 PC (Molecular Devices, Munich, Germany).

\subsection{Quantification of PGE release}

To quantify PGE in supernatants, we used a commercially available enzyme immunoassay (Biotrend Chemikalien $\mathrm{GmbH}$, Cologne, Germany). PGE was measured according to the manufacturer's instructions. Absorbance was read at $450 \mathrm{~nm}$ on a Victor 21420 multilabel counter, and analysis was performed using WorkOut 1.5 (all PerkinElmer, Waltham, MA, USA). Specificity was approximately 


\begin{tabular}{|c|c|c|c|c|c|}
\hline \multirow[b]{2}{*}{ Fatty acid measured } & & \multicolumn{4}{|c|}{ Weight $\%$ of total fatty acids } \\
\hline & & Control & $+\mathrm{AA}$ & + EPA & $+\mathrm{DHA}$ \\
\hline Total saturated & & 39.53 & 42.33 & 41.39 & 45.10 \\
\hline Total $n-9$ & & 36.39 & 28.81 & 29.26 & 24.81 \\
\hline Total n-6 & & 3.62 & 13.59 & 2.93 & 3.62 \\
\hline Total $n-3$ & & 2.67 & 1.84 & 12.77 & 16.02 \\
\hline Linoleic acid & $18: 2 n-6$ & 0.54 & 0.49 & 0.54 & 0.80 \\
\hline Dihomo- $\gamma$-linolenic acid & $18: 3 n-6$ & 0.55 & 0.60 & 0.47 & 0.71 \\
\hline Arachidonic acid & $20: 4 n-6$ & 2.16 & 8.60 & 1.65 & 1.82 \\
\hline$\alpha$-Linolenic acid & $18: 3 n-3$ & 0.01 & ND & ND & 0.03 \\
\hline Eicosapentaenoic acid & $20: 5 n-3$ & 0.34 & 0.22 & 4.42 & 3.94 \\
\hline Docosapentaenoic acid & $22: 5 n-3$ & 1.11 & 0.84 & 6.96 & 2.97 \\
\hline Docosahexaenoic acid & $22: 6 n-3$ & 1.19 & 0.78 & 1.32 & 8.95 \\
\hline
\end{tabular}

TABLE 2 Incorporation of arachidonic acid (AA), eicosapentaenoic acid (EPA) and docosahexaenoic acid (DHA) into canine chondrocytes after 8 days of cultivation in medium containing $10 \mu \mathrm{m}$ of the indicated fatty acid $(N=1)$
$100 \%$ for prostaglandin E3, $100 \%$ for prostaglandin E2 and $27 \%$ for prostaglandin E1.

\section{7 | Statistical Analysis}

Each experiment was performed in triplicate with cells pooled from six individuals in three independent experiments except for the PGE assay and Griess assay, which were carried out in duplicate. Real-time qPCR data were expressed as normalized $\log _{2}$ transformed expression and are presented as box plot representing the maximum and minimum value and " + " representing the mean. Data of PGE and NO are shown in columns as means \pm standard deviation (SD). To compare the effects of fatty acid supplements and the stimulant IL-1 $\beta$, all data were analysed by two-factorial analysis of variance (AV). In case of significant differences between treatments, a Dunnett post hoc test was performed to determine significant differences between groups. Significance levels for AV and Dunnett test were set at $\alpha=0.01$. All data and statistical analysis were conducted using GraphPad Prism 7 software (GraphPad Software, La Jolla, CA, USA).

\section{3 | RESULTS}

\subsection{Fatty acid uptake by chondrocytes}

In order to determine the optimal concentration for incorporation of AA, DHA and EPA into the cells, we analysed the fatty acid uptake via gas-liquid chromatography. In the unsupplemented chondrocytes, $\mathrm{n}-6$ fatty acids predominated over $\mathrm{n}-3$ fatty acids, leading to a high n-6-to-n-3 ratio. In contrast, after supplementation with DHA or EPA, the cells rapidly replaced $n-6$ fatty acid with $n-3$ fatty acids, resulting in a reversed $n-6 / n-3$ ratio (Table 2 ). We show that chondrocytes not only incorporated all three fatty acids in a dose-dependent manner (Figure 1a) but also metabolized them readily, as indicated for example by increased DPA levels in EPA-supplemented cells (Table 2). The concentration of all fatty acids increased over 4 days of supplementation. Thereafter, a slight decrease in fatty acid uptake was detected (Figure 1b).

\subsection{Gene expression analysis of matrix remodelling enzymes}

Figure 2 presents the results for the gene expression of several cartilage matrix proteinases and their inhibitor TIMP-2. In the presence of AA or DHA, MMP-3 gene expression was increased twofold $(p<.001)$ compared to untreated control cells. The expression of ADAMTS-5 ( $p>.99$ for AA; $p=.89$ for DHA), MMP-13 ( $p=.97$ for AA; $p>.99$ for DHA) and TIMP-2 ( $p=.36$ for AA; $p=.19$ for DHA) was not altered significantly in cells treated with AA or DHA. In chondrocytes incubated with EPA, no significant changes were detected for the expression of the cartilage matrix proteinases tested ( $p$ > .99 for MMP-13; $p=.48$ for MMP-3; $p=.54$ for ADAMTS-5) or their inhibitor $(p=.20$ for TIMP-2).

In cells exposed to IL- $1 \beta$, incorporation of AA significantly decreased MMP-3 expression compared to controls treated with IL-1 $\beta$ alone $(p<.001)$. The downregulation was comparable to the twofold downregulation of MMP-3 induced by Ibu $(p<.001)$. On the other hand, AA induced a fourfold increase in ADAMTS-5 expression in comparison with the IL-treated control $(p<.001)$. EPA or DHA could not change the expression of MMP-3 ( $p=.06$ for EPA; $p=.91$ for DHA) or ADAMTS-5 ( $p=.10$ for EPA; $p=.27$ for DHA) after induction of inflammation by IL-1 $\beta$. Although apparent changes in the gene expression of MMP-13 were observed in cells treated with $\mathrm{AA}(p=.07)$, EPA $(p=.03)$ and DHA $(p=.52)$, the differences were not significant compared to IL-stimulated control cells. Furthermore, no significant differences in TIMP-2 expression were identified among all fatty acid treatments $(p=.03$ for AA; $p=.37$ for EPA; $p=.15$ for DHA) in cells stimulated with IL-1 $\beta$. The trend for all genes following treatment with Ibu was towards a decrease in expression. However, when compared to the IL-treated control cells, this trend was significant for MMP-3 

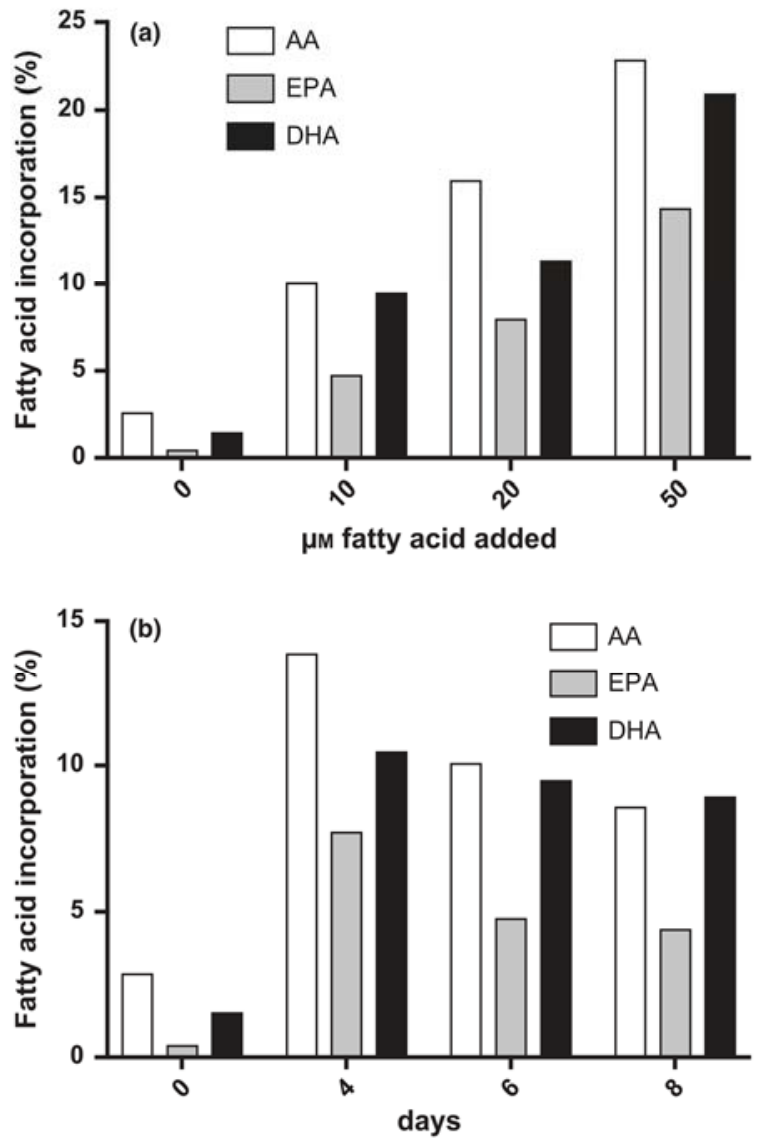

FIGURE 1 Dose-dependent (a) and time-dependent (b) uptake of arachidonic acid (AA), docosahexaenoic acid (DHA) and eicosapentaenoic acid (EPA) by canine chondrocytes. Cells were incubated with different concentrations of fatty acids, harvested at different time points and examined via gas-liquid chromatography analysis. (a) shows percentage of incorporation for each fatty acid in a concentration of $0,10,20$ or $50 \mu \mathrm{m}$ over 6 days, and (b) shows percentage of incorporation after supplementation with $10 \mu \mathrm{m}$ fatty acid over $0,4,6$ or 8 days $(N=1)$

$(p<.001)$ but not for MMP-13 $(p=.04)$, ADAMTS-5 $(p=.82)$ and TIMP-2 $(p=.54)$.

\section{3 | Gene expression analysis of iNOS and synthesis of NO}

As shown in Figure 3, none of the fatty acids could affect iNOS gene expression ( $p=.69$ for $\mathrm{AA} ; p>.99$ for EPA; $p=.4$ for DHA) and generation of $\mathrm{NO}(p>.99$ for all) in cells without induction of inflammation

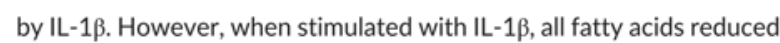
the production of NO and iNOS gene expression. Compared to ILstimulated control cells, both EPA and AA resulted in a significantly lower expression of iNOS, concomitant with a significantly lower NO production $(p<.001)$. AA reduced the rate of NO by $\sim 50 \%$ and downregulated iNOS over 40 times. EPA was not that effective, but still lowered iNOS expression threefold. Supplementation with DHA did neither change NO $(p=.21)$ nor gene expression of iNOS $(p=.03)$. A small, however, significant increase in iNOS expression caused by Ibu $(p<.001)$ was not reflected in a significant increase in NO in the supernatant $(p=.92)$,

\subsection{Gene expression analysis of COX-2 and synthesis of PGE}

Figure 4 shows the effects of fatty acids on the gene expression of COX-2, the key enzyme for eicosanoid synthesis, and the corresponding level of PGE in the supernatants. Cells exposed to AA highly increased production of PGE. On average, AA alone led to a 10-fold upregulation in PGE production compared to untreated control cells $(p<.001)$. AA together with IL-1 $\beta$ caused a 40 -fold increase in PGE production compared to control cells treated with IL-1 $\beta$ alone $(p<.001)$. But in either case, COX-2 gene expression was not affected $(p=.99$ without IL-1 $\beta ; p=.78$ with IL-1 $\beta$ ). EPA and DHA in combination with IL-1 $\beta$ showed no effect as it changed neither the amount of PGE ( $p=.03$ for EPA; $p=.48$ for DHA) nor the COX-2 mRNA level ( $p=.98$ for EPA; $p=.53$ for DHA). In the absence of IL-1 $\beta$, EPA and DHA also did not induce any changes in PGE synthesis $(p=.97$ for EPA; $p=.87$ for DHA) or COX-2 expression ( $p=.93$ for EPA; $p=.88$ for DHA). As expected, Ibu reduced the production of PGE significantly $(p<.001)$ which was accompanied by a lower expression of COX-2 compared to IL-treated control cells $(p=.03)$.

\section{DISCUSSION}

Firstly, we demonstrated that fatty acids are rapidly incorporated into chondrocytes in a dose-dependent manner. The steady state was reached after 4 days of supplementation. The incorporation of EPA was less efficient than that of DHA, which is in accordance with in vitro data from canine mastocytoma cells (Seidel, Gueck, \& Fuhrmann, 2005) and in vivo data from canine erythrocytes (Stoeckel, Bachmann, Dobeleit, \& Fuhrmann, 2013). Furthermore, the fatty acids were converted into fatty acid derivatives, probably causing the slight decrease in fatty acid concentration at the end of the supplementation period. One fatty acid derivative that was markedly increased after the supplementation of EPA is docosapentaenoic acid (DPA). DPA is an elongation product of EPA and can be further metabolized to DHA by $\Delta 6$-desaturase (Kaur, Cameron-Smith, Garg, \& Sinclair, 2011). However, in humans, the conversion of DPA to DHA has been proven to be very limited and therefore an accumulation of DPA occurs (Brenna, Salem, Sinclair, \& Cunnane, 2009). Canine studies suggest this could be the case in dogs as well (Bauer, 2007; Harris et al., 2007). Our findings support this hypothesis, as we found an increase in EPA and DPA, but not DHA in our cells.

It is known that chondrocytes have only limited access to nutrients due to the avascular, dense and negatively charged matrix (Villalvilla, Gómez, Largo, \& Herrero-Beaumont, 2013). However, feeding studies provide evidence that diets rich in $n-3$ fatty acids alter the fatty acid composition in canine serum (Barrouin-Melo et al., 2016; Hall, 

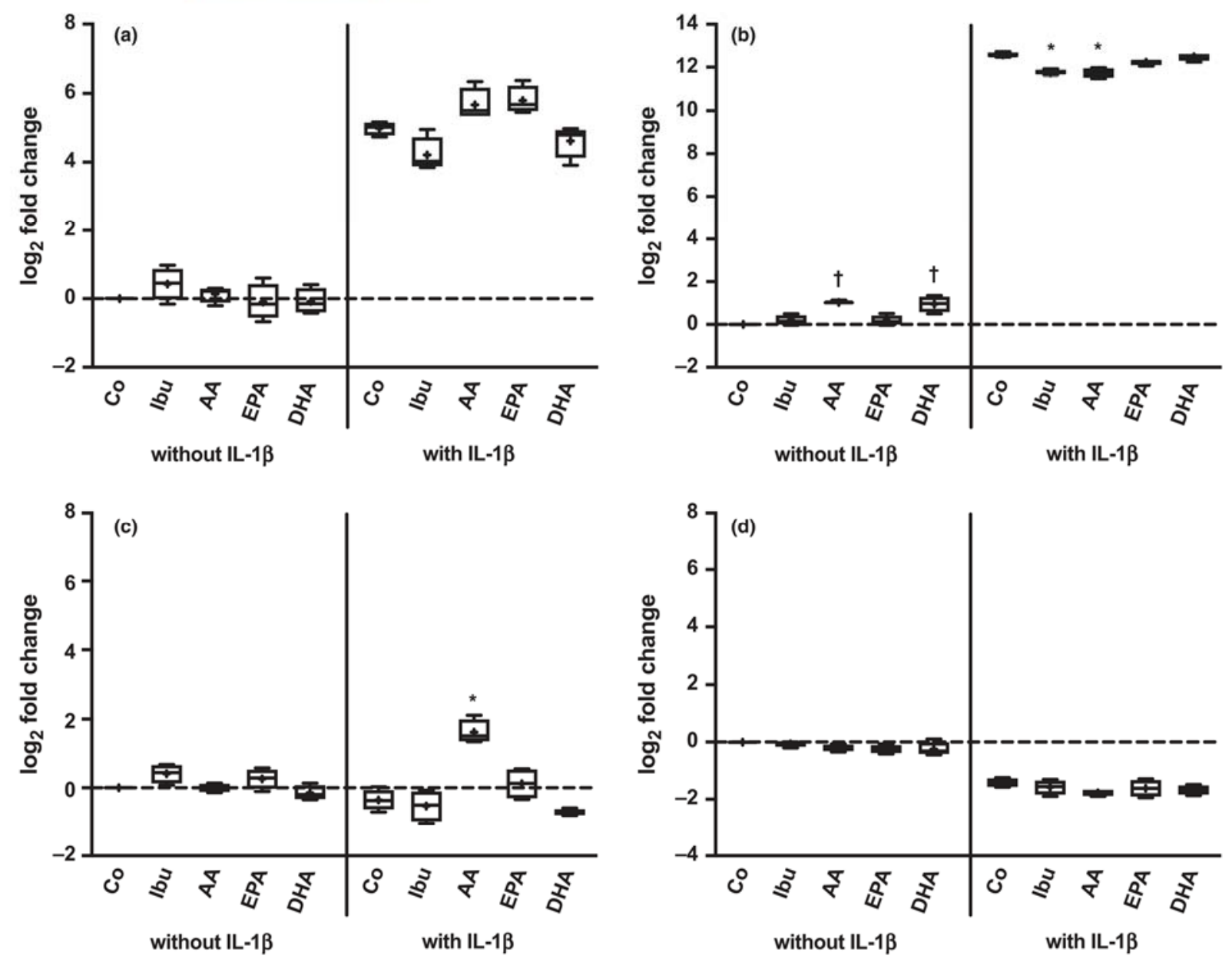

FIGURE 2 Effects of different fatty acids on mRNA levels of matrix metalloproteinase-13 (MMP-13) (a), matrix metalloproteinase-3 (MMP3) (b), a disintegrin and metalloproteinase with thrombospondin motif enzyme-5 (ADAMTS-5) (c) and tissue inhibitor of metalloproteinase-2 (TIMP-2) (d). Cells were supplemented with or without $10 \mu \mathrm{m}$ arachidonic acid (AA), docosahexaenoic acid (DHA), eicosapentaenoic acid (EPA),

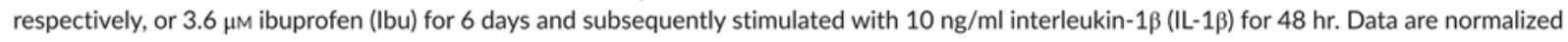
to TATA-binding protein and glycerinaldehyde 3-phosphate dehydrogenase and presented as $\log _{2}$ fold changes relative to untreated controls (box plot with whiskers representing maximum and minimum and + representing the mean. Cells were pooled from six individuals; $N=4$.) $\dagger$ indicates a statistically significant difference from the untreated control, and *indicates a statistically significant difference from the IL-1 $\beta$ treated control $(p<.001)$

Picton, Skinner, Jewell, \& Wander, 2006; Mehler et al., 2016) and that fatty acids are generally transported to the joints bound to albumin or lipoproteins (Arkill \& Winlove, 2006). To mimic the process of fatty acid transport, we included $5 \%$ of FCS in the culture medium. Chondrocytes receive nutrients, including fatty acids, by diffusion through the synovial fluid and vascular channels in the subchondral bone (Pan et al., 2012; Villalvilla et al., 2013). In horses, it was recently shown that long-term oral administration of high amounts of PUFA (several grams per day) increases the synovial concentration of the fatty acids (Ross-Jones et al., 2014). After 90 days of supplementation, fatty acid levels reached $\sim 1.3 \%$ (EPA) and $\sim 1.5 \%$ (DHA) of the total fatty acids in the synovial fluid. This effect could be slightly increased to $\sim 1.5 \%$ and $\sim 1.8 \%$, respectively, by even higher amounts of PUFA in the diet (Ross-Jones et al., 2016). However, there is little knowledge about the final concentration that is achievable in the synovial fluid of dogs after dietary fatty acid supplementation (Damyanovich, Staples, Chan, \& Marshall, 1999). Therefore, we decided to use the lowest concentration that could alter the fatty acid composition of chondrocytes in our in vitro model. The cells were incubated in medium containing $10 \mu \mathrm{g}$ fatty acid $/ \mathrm{ml}$ over a prolonged treatment period of 8 days. These conditions allow a better comparison with the physiological situation in the canine joint after long-term dietary intervention with fatty acids. This is in contrast to other studies with human and bovine chondrocytes, which used concentrations up to $300 \mu \mathrm{g} / \mathrm{ml}$ (Curtis et al., 2002) or incubated their cells in the supplemented medium for only 8 (Zainal et al., 2009) to $24 \mathrm{hr}$ (Hurst et al., 2009).

It is well recognized that addition of $\mathrm{IL}-1 \beta$ to chondrocyte cultures induces an inflammatory response comparable to that 


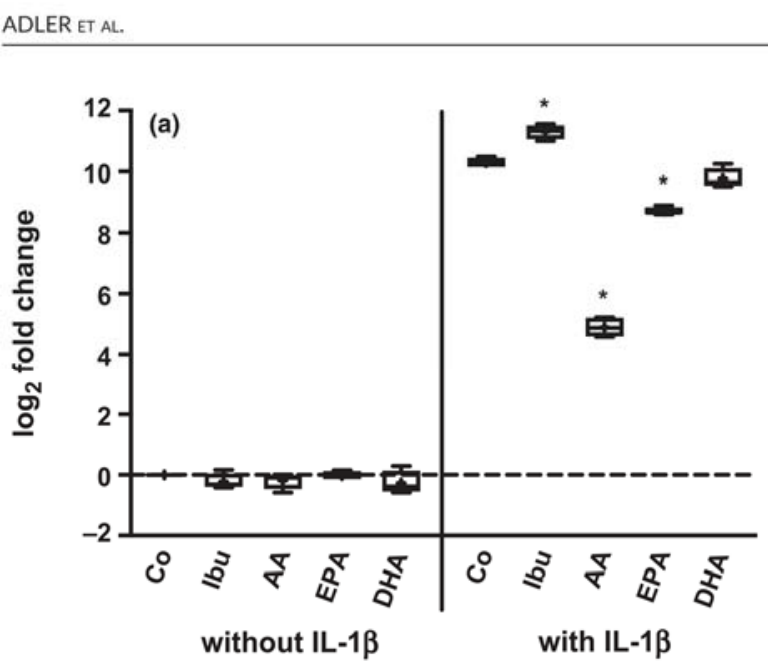

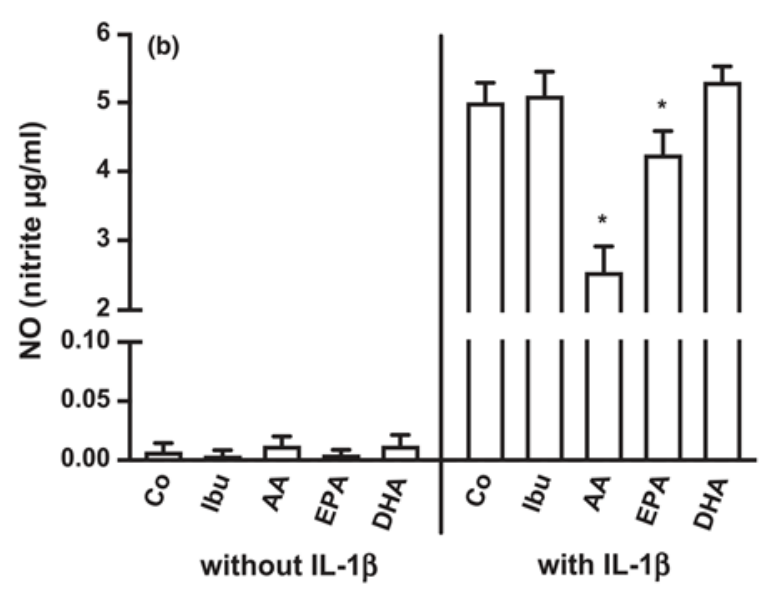

FIGURE 3 Effects of fatty acid supplementation on mRNA levels of inducible nitric oxide synthase (iNOS) (a) and on nitric oxide (NO) production (b). Cells were supplemented with $10 \mu \mathrm{m}$ fatty acids or $3.6 \mu \mathrm{m}$ ibuprofen (lbu) for 6 days followed by incubation with or without $10 \mathrm{ng} / \mathrm{ml}$ interleukin-1 $\beta$ (IL-1 $1 \beta$ ) for another $48 \mathrm{hr}$. Data of iNOS gene expression are normalized to TATA-binding protein and glycerinaldehyde 3-phosphate dehydrogenase and presented as $\log _{2}$ fold changes relative to untreated controls (box plot with whiskers representing maximum and minimum and + representing the mean); data of $\mathrm{NO}$ production are expressed as means $\pm \mathrm{SD}$ (cells pooled from six individuals; $N=4$ ).*indicates a statistically significant difference from the IL-1 $\beta$-treated control $(p<.001)$

observed in OA (Cook, Anderson, Kreeger, \& Tomlinson, 2000; Kuroki, Stoker, \& Cook, 2005; Rai et al., 2008). In this study, stimulation with IL-1 $\beta$ led to an increase in all degeneration markers with the exception of ADAMTS-5. Our observation that ADAMTS-5 could not be induced by IL-1 $\beta$ is also consistent with other reports (Curtis et al., 2002; Tortorella et al., 2001), supporting the hypothesis that ADAMTS- 5 is rather constitutively expressed and is not primarily responsible for the cytokine-induced cartilage degeneration. Overall, this pattern of responsiveness was comparable to naturally occurring OA in dogs. We therefore conclude that IL-1 $\beta$-stimulated canine chondrocytes provide an appropriate in vitro model for canine OA.
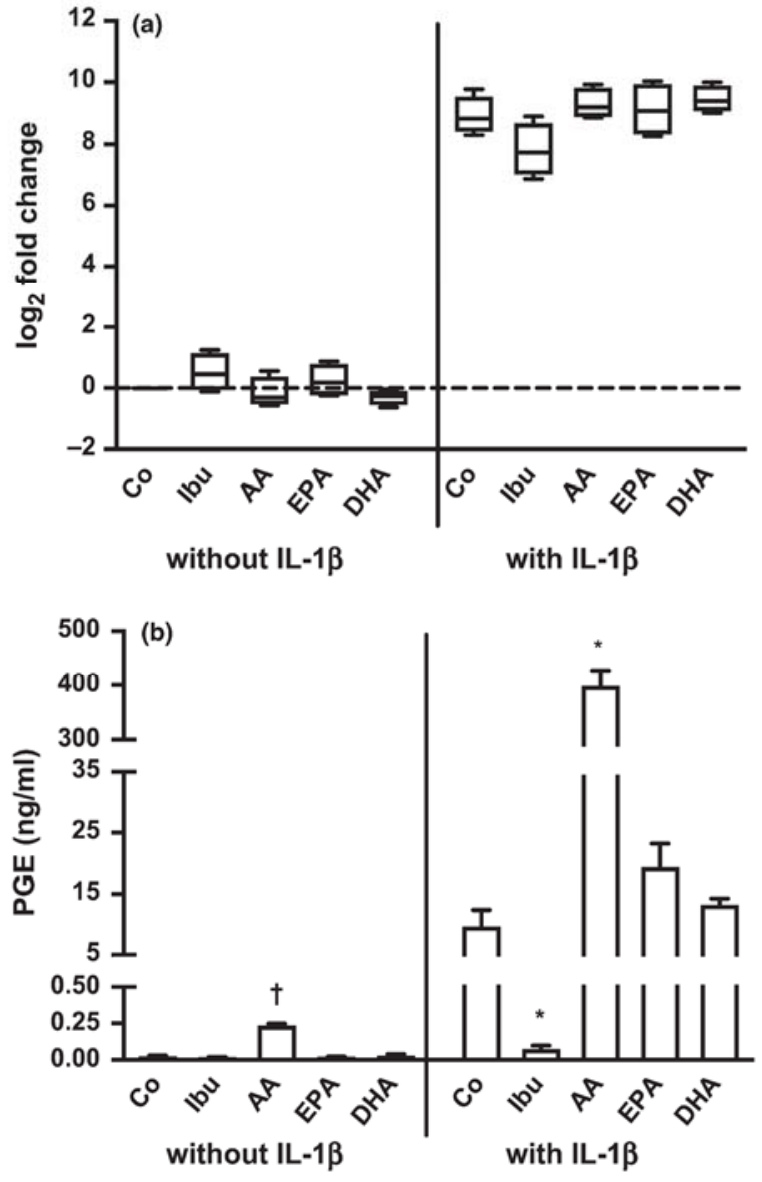

FIGURE 4 Changes of cyclooxygenase-2 (COX-2) mRNA levels (a) and prostaglandin $E$ (PGE) release (b) in canine chondrocytes. Cells were cultured for 6 days in medium containing $10 \mu \mathrm{M}$ eicosapentaenoic acid (EPA), docosahexaenoic acid (DHA), arachidonic acid (AA) or $3.6 \mu \mathrm{m}$ ibuprofen (Ibu) and subsequently stimulated with $10 \mathrm{ng} / \mathrm{ml}$ interleukin-1 $\beta$ (IL-1 $\beta$ ) for another $48 \mathrm{hr}$ or left unstimulated. (a) RT-qPCR data of COX-2 expression are normalized to TATA-binding protein and glycerinaldehyde 3-phosphate dehydrogenase and presented as $\log _{2}$ fold change relative to untreated control cells (box plot with whiskers representing maximum and minimum and + representing the mean); PGE production was measured by ELISA, and results are expressed as means $\pm S D$ (cells pooled from six individuals; $N=4$ in triplicates). $\dagger$ indicates a statistically significant difference from the untreated control, and *indicates a statistically significant difference from the IL-1 $\beta$-treated control $(p<.001)$

The expression of chondroprotective TIMP-2 is known to be decreased in canine osteoarthritic cartilage (Clements et al., 2009), while in human and bovine cartilage, TIMP-2 expression was shown to be unaffected by OA (Kevorkian et al., 2004; Zafarullah et al., 1996). Here, we once again provide evidence that TIMP-2 is expressed in a species-specific manner.

We evaluated the efficiency of $n-3$ and $n-6$ fatty acids to attenuate key markers of OA in a cellular model. Several proteinases cleave cartilage matrix and are therefore major contributors to cartilage 
degradation (Murphy \& Lee, 2005). Among these, the ADAMTSs (Tortorella et al., 2001) and the MMPs (Poole et al., 2003) play an important part. In our study, EPA and DHA did not alter the expression of MMP-3, while AA reduced MMP-3 expression by $~ 50 \%$, that is, to the same level as the positive control lbu. AA on the other hand increased ADAMTS- 5 expression fourfold. It could be argued that the elevation of ADAMTS- 5 mRNA levels may attenuate the lowering effect on MMP-3 expression, consequently neutralizing or reversing its positive effect on cartilage degeneration. However, ADAMTS-5 was neither induced by IL- $1 \beta$ nor significantly decreased by the positive control lbu. This is contradictory to other studies, showing a decrease in ADAMTS-5 expression following treatment of chondrocytes obtained directly from osteoarthritic joints with the NSAID meloxicam (Budsberg et al., 2013). We therefore conclude that in OA, ADAMTS- 5 expression is regulated by a mechanism that is not associated with IL-1 $\beta$. These results, however, do not permit to draw final conclusions on ADAMTS-5 expression in fatty acid-treated chondrocytes. MMP-13 is considered to be the key enzyme involved in cartilage degeneration (van den Berg, 2011). Still, none of the fatty acids included in our study significantly altered the gene expression of MMP-13. Likewise, the fatty acids had no effect on TIMP-2 expression and did not suppress the IL-induced increase in matrix proteinase expression.

Recent in vivo studies have shown that treating osteoarthritic dogs with n-6-rich corn oil led to the attenuation of oxidative stress markers in the blood. The improvement was almost comparable to dogs receiving fish oil (Barrouin-Melo et al., 2016). This is the first study to show that not only EPA but also $n-6$ fatty acids may be beneficial in inflammatory diseases. Our results add further weight to the conclusions drawn from this feeding trial.

Docosahexaenoic acid turned out to be the less effective fatty acid, as it barely altered the markers examined. This is consistent with other studies which reported DHA to be the less effective fatty acid as well (Zainal et al., 2009). However, it has been shown that DHA was initially more efficient than EPA but this efficiency declined over time (Wann, Mistry, Blain, Michael-Titus, \& Knight, 2010). As we used a prolonged incubation period of 8 days and a low concentration of $10 \mu \mathrm{g} \mathrm{DHA} / \mathrm{ml}$, it remains to be investigated whether DHA had a significant effect at the beginning of our study period or in higher concentrations.

Besides MMPs, NO and the eicosanoid PGE are known to be key mediators in the pathogenesis of OA (Abramson, 2008; Attur, Dave, Abramson, \& Amin, 2012). Here, we report that EPA and AA both effectively reduced NO levels. Our results indicate that this is due to changes in gene expression of iNOS. Of particular note is that AA was more potent in inhibiting NO production than EPA.

It is well known that the availability of fatty acids as substrates for COX and LOX enzymes is largely dependent on cell membrane composition, which thus influences the balance of inflammatory and anti-inflammatory eicosanoids and other autacoids like resolvins and lipoxins (Arterburn, Hall, \& Oken, 2006). AA is a precursor of the proinflammatory 2 series of prostaglandins and therefore gives rise to a high concentration of $\mathrm{PGE}_{2}$ (Hurst et al., 2009). Accordingly, the PGE production was markedly increased by AA supplementation. Whether this effect outweighes the positive effects of $A A$ on gene expression of NO and MMP-3 needs to be evaluated further. In accordance with other studies, low concentrations of AA could not alter COX-2 expression, even though PGE was strongly induced. Therefore, we suppose that only high doses of fatty acids may alter gene expression of COX-2 and that low doses change the production of eicosanoids by other means.

As the PGE assay used here did not distinguish between highinflammatory prostaglandin $E_{2}\left(P E_{2}\right)$ and low-inflammatory prostaglandin $E_{3}\left(P G E_{3}\right)$, we cannot draw definitive conclusions regarding which series of PGE was altered and whether this will change the overall inflammatory response in our model. DHA and EPA are precursors of the 3 series of prostaglandins. We assume that EPA and DHA supplementation lowered $P G E_{2}$ levels while increasing $\mathrm{PGE}_{3}$ levels. However, with respect to immune cell responses, it has been shown that relative levels of $\mathrm{PGE}_{3}$ are very low in dogs compared to $\mathrm{PGE}_{2}$ with a ratio of approximately 1:500 (Kearns et al., 1999).

Polyunsaturated fatty acids are essential nutrients, and regular intake is necessary for maintaining overall health. Overconsumption of $n-6$ fatty acids in humans leads to a shift in the eicosanoid profile towards chronic inflammation not only in the joint, but in the whole body. Based on these findings, it is generally recommended for humans to keep a ratio of n-6 to n-3 of less than 4:1 (Lopez, 2012). However, this recommendation cannot be equally applied to dogs. N-3 alpha-linolenic acid (ALA) is another essential PUFA which contributes to the n-3 fatty acid pool and has only few anti-inflammatory properties. ALA can be converted to EPA or DHA, but conversion rates have been proven to be rather inefficient in dogs (Bauer, 2007). Therefore, the level of EPA and DHA is probably physiologically more relevant for dogs than the n-3-to-n-6 ratio (Bauer, 2007; Mehler et al., 2016).

Here, we present evidence that adds further weight to the benefits of feeding a diet rich in EPA and DHA reported in OA dogs in vivo (Fritsch et al., 2010; Moreau et al., 2013; Roush et al., 2010) and provide molecular mechanisms to explain these effects. Of particular importance is that the n-6 fatty acid AA could decrease inflammatory markers comparable to $n-3$ fatty acids. An exclusive management of DHA and EPA in dogs with OA should therefore be regarded with caution.

\section{ACKNOWLEDGEMENTS}

The authors would like to thank Dr. Ronny Schulz from the Centre for Biotechnology and Biomedicine, University of Leipzig, for his professional consultation and Bastian Kaiser, from the Institute of Veterinary Physiology, Faculty of Veterinary Medicine, University of Leipzig, for his advices regarding gene expression analysis. This work was supported by Boehringer Ingelheim Animal Health $\mathrm{GmbH}$, Ingelheim am Rhein, Germany.

\section{ORCID}

H. Fuhrmann (iD) http://orcid.org/0000-0002-6767-4435 


\section{REFERENCES}

Abramson, S. B. (2008). Osteoarthritis and nitric oxide. Osteoarthritis Cartilage, 16(Suppl 2), S15-S20.

Amin, A. R., Attur, M., Patel, R. N., Thakker, G. D., Marshall, P. J., Rediske, J., ... Abramson, S. B. (1997). Superinduction of cyclooxygenase-2 activity in human osteoarthritis-affected cartilage. Influence of nitric oxide. The Journal of Clinical Investigation, 99, 1231-1237.

Arkill, K. P., \& Winlove, C. P. (2006). Fatty acid transport in articular cartilage. Archives of Biochemistry and Biophysics, 456, 71-78.

Arterburn, L. M., Hall, E. B., \& Oken, H. (2006). Distribution, interconversion, and dose response of $\mathrm{n}-3$ fatty acids in humans. The American Journal of Clinical Nutrition, 83, 1467S-1476S.

Attur, M., Al-Mussawir, H. E., Patel, J., Kitay, A., Dave, M., Palmer, G., .. Abramson, S. B. (2008). Prostaglandin E2 exerts catabolic effects in osteoarthritis cartilage: Evidence for signaling via the EP4 receptor. The Journal of Immunology, 181, 5082-5088.

Attur, M., Dave, M., Abramson, S. B., \& Amin, A. (2012). Activation of diverse eicosanoid pathways in osteoarthritic cartilage. A lipidomic and genomic analysis. Bulletin of the NYU Hospital for Joint Diseases, 70, 99-108.

Aupperle, H., Thielebein, J., Kiefer, B., März, I., Dinges, G., Schoon, H. A., \& Schubert, A. (2009). Expression of genes encoding matrix metalloproteinases (MMPs) and their tissue inhibitors (TIMPs) in normal and diseased canine mitral valves. Journal of Comparative Pathology, 140, 271-277.

Barrouin-Melo, S. M., Anturaniemi, J., Sankari, S., Griinari, M., Atroshi, F., Ounjaijean, S., \& Hielm-Bjorkman, A. K. (2016). Evaluating oxidative stress, serological- and haematological status of dogs suffering from osteoarthritis, after supplementing their diet with fish or corn oil. Lipids in Health and Disease, 15, 139.

Bauer, J. E. (2007). Responses of dogs to dietary omega-3 fatty acids. Journal of the American Veterinary Medical Association, 231, 1657-1661.

Bee, A., Barnes, A., Jones, M. D., Robertson, D. H., Clegg, P. D., \& Carter, S. D. (2000). Canine TIMP-2: Purification, characterization and molecular detection. The Veterinary Journal, 160, 126-134.

Bound, N.J., Upjohn, M.J., Jackson, S., \& Baines, S.J. (2011). Asessment of veterinary practitioners in the British Isles' approaches towards the management of canine osteoarthritis. Veterinary Record, 168, 563. https://doi.org/10.1136/vr.d1021.

Brenna, J.T., Salem, N. Jr, Sinclair, A.J., \& Cunnane, S.C. (2009). alphaLinolenic acid supplementation and conversion to $n-3$ long-chain polyunsaturated fatty acids in humans. Prostaglandins, Leukotrienes, and Essential Fatty Acids, 80, 85-91.

Budsberg, S. C., Stoker, A. M., Johnston, S. A., Liska, W., Reno, L. R., \& Cook, J. L. (2013). In vitro effects of meloxicam on metabolism in articular chondrocytes from dogs with naturally occurring osteoarthritis. American Journal of Veterinary Research, 74, 1198-1205.

Clements, D. N., Fitzpatrick, N., Carter, S. D., \& Day, P. J. (2009). Cartilage gene expression correlates with radiographic severity of canine elbow osteoarthritis. The Veterinary Journal, 179, 211-218.

Cook, J. L., Anderson, C. C., Kreeger, J. M., \& Tomlinson, J. L. (2000). Effects of human recombinant interleukin-1 beta on canine articular chondrocytes in three-dimensional culture. American Journal of Veterinary Research, 61, 766-770.

Curtis, C. L., Rees, S. G., Little, C. B., Flannery, C. R., Hughes, C. E., Wilson, C., ... Caterson, B. (2002). Pathologic indicators of degradation and inflammation in human osteoarthritic cartilage are abrogated by exposure to n-3 fatty acids. Arthritis and Rheumatism, 46, 1544-1553.

Damyanovich, A. Z., Staples, J. R., Chan, A. D., \& Marshall, K. W. (1999). Comparative study of normal and osteoarthritic canine synovial fluid using $500 \mathrm{MHz} 1 \mathrm{H}$ magnetic resonance spectroscopy. Journal of Orthopaedic Research, 17, 223-231.

Fritsch, D., Allen, T., Dodd, C., Jewell, D., Sixby, K., Leventhal, P., \& Hahn, K. (2010). Dose-titration effects of fish oil in osteoarthritic dogs. Journal of Veterinary Internal Medicine, 24, 1020-1026.
Fuhrmann, H., Zimmermann, A., Gück, T., \& Oechtering, G. (2006). Erythrocyte and plasma fatty acid patterns in dogs with atopic dermatitis and healthy dogs in the same household. Canadian Journal of Veterinary Research, 70, 191-196.

Gomis-Ruth, F. X., Maskos, K., Betz, M., Bergner, A., Huber, R., Suzuki, K., ... Bode, W. (1997). Mechanism of inhibition of the human matrix metalloproteinase stromelysin-1 by TIMP-1. Nature, 389, 77-81.

Hall, J. A., Picton, R. A., Skinner, M. M., Jewell, D. E., \& Wander, R. C. (2006). The $(n-3)$ fatty acid dose, independent of the $(n-6)$ to $(n-3)$ fatty acid ratio, affects the plasma fatty acid profile of normal dogs. The Journal of Nutrition, 136, 2338-2344.

Harris, W. S., DiRienzo, M. A., Sands, S. A., George, C., Jones, P. G., \& Eapen, A. K. (2007). Stearidonic acid increases the red blood cell and heart eicosapentaenoic acid content in dogs. Lipids, 42, 325-333.

Henrotin, Y., Sanchez, C., \& Balligand, M. (2005). Pharmaceutical and nutraceutical management of canine osteoarthritis: Present and future perspectives. The Veterinary Journal, 170, 113-123.

Houard, X., Goldring, M. B., \& Berenbaum, F. (2013). Homeostatic mechanisms in articular cartilage and role of inflammation in osteoarthritis. Current Rheumatology Reports, 15, 375-385.

Hurst, S., Rees, S. G., Randerson, P. F., Caterson, B., \& Harwood, J. L. (2009). Contrasting effects of n-3 and n-6 fatty acids on cyclooxygenase- 2 in model systems for arthritis. Lipids, 44, 889-896.

Johnston, S. A. (1997). Osteoarthritis. Joint anatomy, physiology, and pathobiology. The Veterinary Clinics of North America - Small Animal Practice, 27, 699-723.

Kaps, C., Fuchs, S., Endres, M., Vetterlein, S., Krenn, V., Perka, C., \& Sittinger, M. (2004). Molekulare Charakterisierung von gezüchteten humanen dreidimensionalen Chondrozytentransplantaten. Der Orthopäde, 33, 76-85.

Kaur, G., Cameron-Smith, D., Garg, M., \& Sinclair, A. J. (2011). Docosapentaenoic acid (22:5n-3): A review of its biological effects. Progress in Lipid Research, 50, 28-34.

Kearns, R. J., Hayek, M. G., Turek, J. J., Meydani, M., Burr, J. R., Greene, R. J., ... Reinhart, G. A. (1999). Effect of age, breed and dietary omega-6 $(n-6)$ : Omega-3 (n-3) fatty acid ratio on immune function, eicosanoid production, and lipid peroxidation in young and aged dogs. Veterinary Immunology and Immunopathology, 69, 165-183.

Kenneth, W., Lima, E. G., Liming, B., O'Connor, C. J., Jayabalan, P., Stoker, A. M., ... Hung, C. T. (2010). Passaged adult chondrocytes can form engineered cartilage with functional mechanical properties: A canine model. Tissue Engineering Part A, 16, 1041-1051.

Kevorkian, L., Young, D. A., Darrah, C., Donell, S. T., Shepstone, L., Porter, S., ... Clark, I. M. (2004). Expression profiling of metalloproteinases and their inhibitors in cartilage. Arthritis and Rheumatism, 50, 131-141.

Kuroki, K., Cook, J. L., Stoker, A. M., Turnquist, S. E., Kreeger, J. M., \& Tomlinson, J. L. (2005). Characterizing osteochondrosis in the dog: Potential roles for matrix metalloproteinases and mechanical load in pathogenesis and disease progression. Osteoarthritis Cartilage, 13, 225-234.

Kuroki, K., Stoker, A. M., \& Cook, J. L. (2005). Effects of proinflammatory cytokines on canine articular chondrocytes in a three-dimensional culture. American Journal of Veterinary Research, 66, 1187-1196.

Lopez, H. L. (2012). Nutritional interventions to prevent and treat osteoarthritis. Part I: focus on fatty acids and macronutrients. American Academy of Physical Medicine and Rehabiliation, 4, S145-S154.

Mehler, S. J., May, L. R., King, C., Harris, W. S., \& Shah, Z. (2016). A prospective, randomized, double blind, placebo-controlled evaluation of the effects of eicosapentaenoic acid and docosahexaenoic acid on the clinical signs and erythrocyte membrane polyunsaturated fatty acid concentrations in dogs with osteoarthritis. Prostaglandins, Leukotrienes, and Essential Fatty Acids, 109, 1-7.

Monteiro-Steagall, B. P., Steagall, P. V. M., \& Lascelles, B. D. X. (2013). Systematic review of nonsteroidal anti-inflammatory drug-induced 
adverse effects in dogs. Journal of Veterinary Internal Medicine, 27, 1011-1019.

Morchón, R., López-Belmonte, J., Bazzocchi, C., Grandi, G., Kramer, L., \& Simón, F. (2007). Dogs with patent Dirofilaria immitis infection have higher expression of circulating IL-4, IL-10 and iNOS mRNA than those with occult infection. Veterinary Immunology and Immunopathology. 115, 184-188.

Moreau, M., Boileau, C., Martel-Pelletier, J., Brunet, J., Laufer, S., \& Pelletier, J. P. (2006). Licofelone reduces progression of structural changes in a canine model of osteoarthritis under curative conditions: Effect on protease expression and activity. The Journal of Rheumatology, 33, 1176-1182.

Moreau, M., Troncy, E., Del Castillo, J. R. E., Bedard, C., Gauvin, D., \& Lussier, B. (2013). Effects of feeding a high omega-3 fatty acids diet in dogs with naturally occurring osteoarthritis. Journal of Animal Physiology and Animal Nutrition, 97, 830-837.

Murphy, G., \& Lee, M. (2005). What are the roles of metalloproteinases in cartilage and bone damage? Annals of the Rheumatic Diseases, 64 iv44-iv47.

Pan, J., Wang, B., Li, W., Zhou, X., Scherr, T., Yang, Y., ... Wang, L. (2012). Elevated cross-talk between subchondral bone and cartilage in osteoarthritic joints. Bone, 51, 212-217.

Peters, I. R., Peeters, D., Helps, C. R., \& Day, M. J. (2007). Development and application of multiple internal reference (housekeeper) gene assays for accurate normalisation of canine gene expression studies. Veterinary Immunology and Immunopathology, 117, 55-66.

Poole, A.R., Nelson, F., Dahlberg, L., Tchetina, E., Kobayashi, M., Yasuda, T. ... Billinghurst, R.C. (2003). Proteolysis of the collagen fibril in osteoarthritis. Biochemical Society Symposium, (70), 115-123.

Rai, M. F., Rachakonda, P. S., Manning, K., Vorwerk, B., Brunnberg, L., Kohn, B., \& Schmidt, M. F. G. (2008). Quantification of cytokines and inflammatory mediators in a three-dimensional model of inflammatory arthritis. Cytokine, 42, 8-17.

Ross-Jones, T., Hess, T., Rexford, J., Ahrens, N., Engle, T., \& Hansen, K. (2014). Effects of Omega-3 long chain polyunsaturated fatty acid supplementation on equine synovial fluid fatty acid composition and prostaglandin E 2. Journal of Equine Veterinary Science, 34, 779-783.

Ross-Jones, T. N., Mcllwraith, C. W., Kisiday, J. D., Hess, T. M., Hansen, D. K., \& Black, J. (2016). Influence of an n-3 long-chain polyunsaturated fatty acid-enriched diet on experimentally induced synovitis in horses. Journal of animal physiology and animal nutrition, 100, 565-577.

Roush, J. K., Cross, A. R., Renberg, W. C., Dodd, C. E., Sixby, K. A., Fritsch, D. A., ... Hahn, K. A. (2010). Evaluation of the effects of dietary supplementation with fish oil omega- 3 fatty acids on weight bearing in dogs with osteoarthritis. Journal of the American Veterinary Medical Association, 236, 67-73.

Seidel, A., Gueck, T., \& Fuhrmann, H. (2005). The Influence of long-chain polyunsaturated fatty acids on total lipid fatty acid composition of a canine mastocytoma cell line. Journal of Veterinary Medicine Series A. Physiology, Pathology, Clinical Medicine, 52, 219-224.

Stoeckel, K., Bachmann, L., Dobeleit, G., \& Fuhrmann, H. (2013). Response of plasma fatty acid profiles to changes in dietary n-3 fatty acids and its correlation with erythrocyte fatty acid profiles in dogs. Journal of Animal Physiology and Animal Nutrition. 97, 1142-1151.

Tortorella, M. D., Malfait, A.-M., Deccico, C., \& Arner, E. (2001). The role of ADAM-TS4 (aggrecanase-1) and ADAM-TS5 (aggrecanase-2) in a model of cartilage degradation. Osteoarthritis Cartilage, 9, 539-552.

van den Berg, W. B. (2011). Osteoarthritis year 2010 in review: Pathomechanisms. Osteoarthritis Cartilage, 19, 338-341.

Villalvilla, A., Gómez, R., Largo, R., \& Herrero-Beaumont, G. (2013). Lipid transport and metabolism in healthy and osteoarthritic cartilage. International Journal of Molecular Sciences, 14, 20793-20808.

Wann, A. K. T., Mistry, J., Blain, E. J., Michael-Titus, A. T., \& Knight, M. M. (2010). Eicosapentaenoic acid and docosahexaenoic acid reduce interleukin-1 $\beta$-mediated cartilage degradation. Arthritis Research \& Therapy, 12, R207.

Wojdasiewicz, P. Poniatowski, LA. \& Szukiewicz, D. (2014). The role of inflammatory and anti-inflammatory cytokines in the pathogenesis of osteoarthritis. Mediators of Inflammation, 2014. Article ID 561459. https://doi.org/10.1155/2014/561459.

Zafarullah, M., Su, S., Martel-Pelletier, J., DiBattista, J. A., Costello, B. G., Stetler-Stevenson, W. G., \& Pelletier, J. P. (1996). Tissue inhibitor of metalloproteinase-2 (TIMP-2) mRNA is constitutively expressed in bovine, human normal, and osteoarthritic articular chondrocytes. Journal of Cellular Biochemistry, 60, 211-217.

Zainal, Z., Longman, A., Hurst, S., Duggan, K., Caterson, B., Hughes, C., \& Harwood, J. (2009). Relative efficacies of omega-3 polyunsaturated fatty acids in reducing expression of key proteins in a model system for studying osteoarthritis. Osteoarthritis Cartilage, 17, 896-905.

How to cite this article: Adler N, Schoeniger A, Fuhrmann $\mathrm{H}$. Polyunsaturated fatty acids influence inflammatory markers in a cellular model for canine osteoarthritis. J Anim Physiol Anim Nutr. 2017;00:1-10. https://doi.org/10.1111/jpn.12804 


\section{DISKUSSION}

\subsection{Isolation und Anzucht von caninen Chondrozyten}

Jeder Chondrozyt empfängt über unterschiedliche Membranrezeptoren Signale aus der umgebenden ECM. Diese Signale können sowohl chemischer als auch mechanischer Natur sein und beeinflussen sowohl die physiologischen als auch die pathologischen Abläufe im Gelenk (WONG und CARTER 2003). In 2D-Kulturen werden die Chondrozyten aus der sie umgebenden ECM isoliert und in das Zellkulturmedium verbracht. Ein wesentlicher Nachteil ist demnach, dass die Interaktion mit der ECM in diesem Kultursystem weitgehend verloren geht (JOHNSON et al. 2016).

Ein Vorteil ist hingegen, dass ohne die umgebende ECM jede Zelle gleichen Zugriff auf die zur Verfügung gestellten Stimulanzien und Supplemente hat (RAI et al. 2008). Daraus ergibt sich erstens eine im Vergleich zu 3D-Modellsystemen bessere Versorgung der Zellen, welche sich vorteilhaft auf die Zellproliferation in 2D-Modellen auswirkt. Dadurch haben 2D-Modelle eine höhere Zellteilungsrate und damit eine höhere Ausbeute an DNA, welche für weitergehende PCR Studien genutzt werden kann (CARON et al. 2012). Zweitens sind Monolayerkulturen besonders leicht durch extern zugesetzte Faktoren zu beeinflussen und eignen sich daher gut für mechanistische Studien. Ohne eine Einbettung in Ersatzmatrizes, wie in 3D-Kulturen üblich, werden die Zellen nicht durch Fremdstoffe von einer artifiziellen 3D-Matrix beeinflusst. Drittens sind daher die beobachteten Effekte nur auf die Zusätze im Zellkulturmedium zurückzuführen und werden nicht durch die Ersatzmatrizes verfälscht (RAI et al. 2008). Trotz aller Vorzüge sollten Untersuchungsergebnisse immer vor dem Hintergrund von Daten aus in vivo Studien interpretiert werden, da es sich um ein Modellsystem handelt, welches die Situation im Gelenk nur nachempfindet.

Aus ethischen Gründen sind wir bestrebt, die Verwendung von Versuchstieren zu vermeiden. In Zusammenarbeit mit Tierarztpraxen der Umgebung konnten wir ein Netzwerk etablieren, in dem uns Hunde zur Entnahme von Knorpelgewebe zur Verfügung gestellt wurden, welche unabhängig von dieser Arbeit euthanasiert wurden. Daraus ergaben sich mehrere Problemfelder, auf die ich im Folgenden eingehen werde. Da in Tierarztpraxen vor allem ältere Tiere zur Euthanasie vorgestellt werden, sind über die Hälfte der Hunde in dieser Studie älter als 10 Jahre. Diese Altersverteilung sollte bei einer Interpretation der Ergebnisse berücksichtigt werden, da in anderen Studien bereits ein Einfluss des Alters auf die Wirkung von Fettsäuren bei Hunden festgestellt werden konnte (KEARNS et al. 1999). Es wurden nur kniegelenkgesunde Hunde als Spender akzeptiert und jedes eröffnete Gelenk vor der Entnahme von Knorpelgewebe auf makroskopische Defekte untersucht. Da 80 \% aller Hunde 
über 8 Jahren von OA betroffen sind (ANDERSON et al. 2018; JOHNSTON 1997), mussten erwartungsgemäß viele Tierkörper vor der Entnahme als Spender ausgeschlossen werden. Daraus ergab sich eine relativ geringe Anzahl an Hunden als Lieferanten für Primärzellen. Um eine größere Anzahl an Versuchen zu ermöglichen, wurden diese Primärzellen über 10 Tage in Monolayerkultur vermehrt, einmalig passagiert und schließlich in unsere Knorpelzellbank aufgenommen.

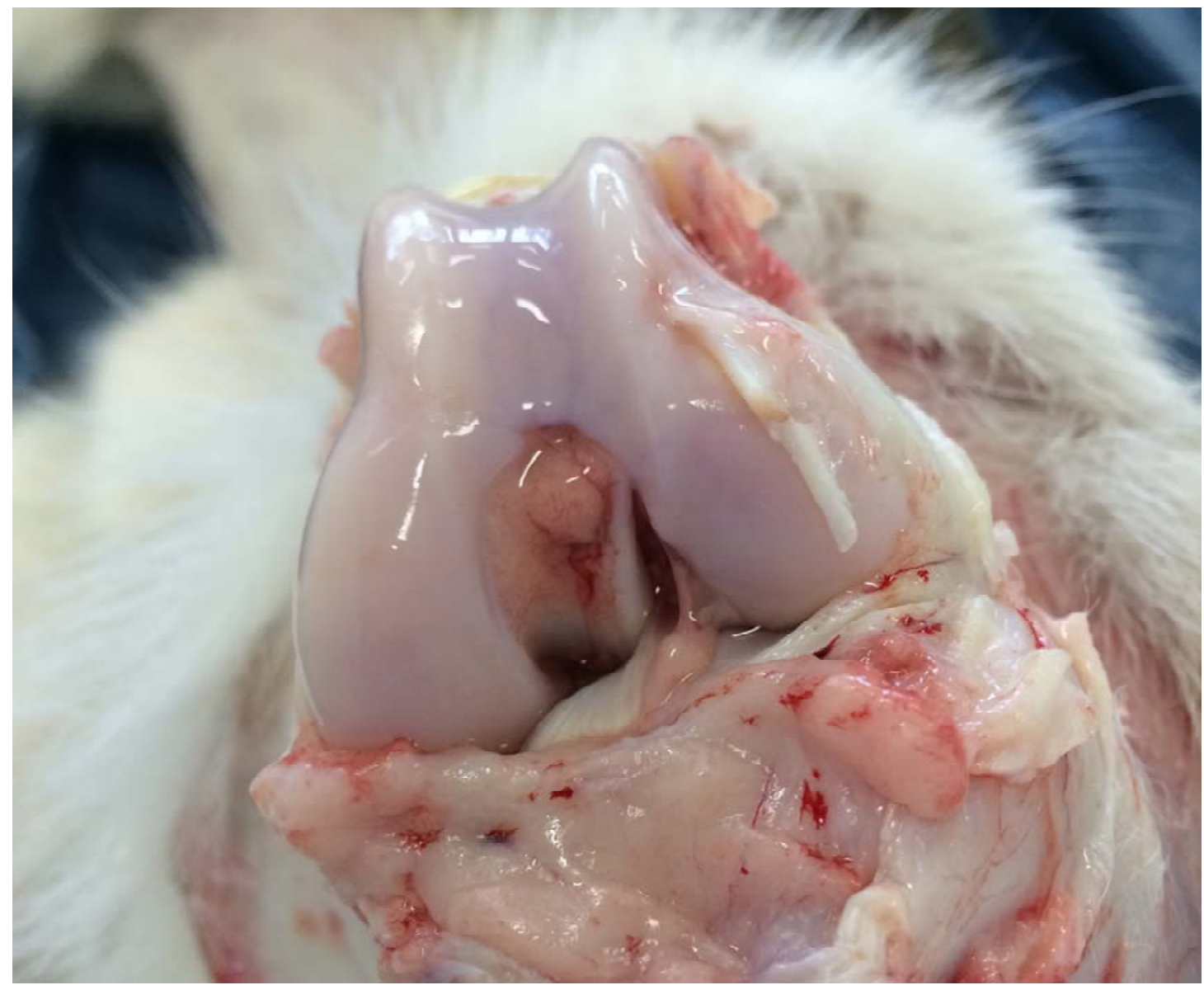

Abbildung 4: Blick auf die Gelenksfläche eines kniegesunden Spenderhundes vor der Gewebsentnahme

Lange Anzuchtzeiten in Monolayerkultur und multiples Passagieren führen zur Dedifferenzierung der Chondrozyten und damit zum Verlust des charakteristischen Phänotyps der Zellen. Der Prozess der Dedifferenzierung beschreibt die Rückentwicklung der Zellen zu ihren Vorläuferzellen (TALLHEDEN et al. 2006). Dedifferenzierte Chondrozyten verlieren ihre Fähigkeit, ECM mit einem hohen Gehalt an Kollagen II, Aggrecan und Glykosaminoglykanen zu produzieren und bilden stattdessen große Mengen an Kollagen I (MINEGISHI et al. 2013; CARON et al. 2012). Ihre Reaktion auf eine Stimulation mit Zytokinen und Wachstumsfaktoren ähnelt eher der Antwort von Fibroblasten. So sind die Zellen nicht mehr in der Lage, bei Stimulation mit IL-1 $\beta$ große Mengen an NO zu produzieren (BLANCO et al. 1995). Dieser 
Prozess wird oft begleitet von einer Veränderung der Zellmorphologie von einer polygonalen zu einer abgeflachten, fibroblastoiden Gestalt. Die Dedifferenzierung einer Chondrozytenkultur ist ein schleichender Prozess. Sie beginnt, wenn die Zellen aus ihrer Matrix gelöst werden und ist erst ab der fünften Passage vollendet (KANG et al. 2007; BENYA et al. 1978).

In dieser Arbeit kommen nur Chondrozyten bis zur zweiten Passage zum Einsatz. Nach Isolation heften sich die Zellen innerhalb von $48 \mathrm{~h}$ an den Boden der Zellkulturflasche und zeigen eine abgeflachte, fibroblastoide Gestalt. Es kommt im gewählten Modell sowohl in den Primärkulturen als auch in der ersten Passage arealweise zum Auftreten von differenzierten Chondrozytennestern. Die Zellen dieser Nester weisen im Gegensatz zur restlichen Kultur eine polygonale Gestalt auf und kapseln sich durch metachromatisches Material von der Umgebung ab. Wie wir mittels Alcianblau-Färbung nachweisen konnten, enthält dieses Material hohe Mengen an anionischen Glykokonjugaten wie Proteoglykanen und Glykosaminoglykanen und zeigt damit typische Eigenschaften von ECM (ROUGHLEY und MORT 2014). Die Ansprechbarkeit der Zellen auf verschiedene Stimulanzien lässt ebenfalls auf eine weitestgehend differenzierte Zellkultur schließen (BLANCO et al. 1995). So kommt es nach der Stimulation mit IL-1 $\beta$ zu einer erhöhten iNOS Expression und damit einhergehenden hohen Produktion an NO. Unter Einfluss von TGF- $\beta$ kann zudem eine größere Zellproliferation beobachtet werden. Insgesamt gehen wir daher davon aus, dass die verwendeten Zellen trotz ihrer Gestalt größtenteils einen differenzierten Phänotyp aufweisen.

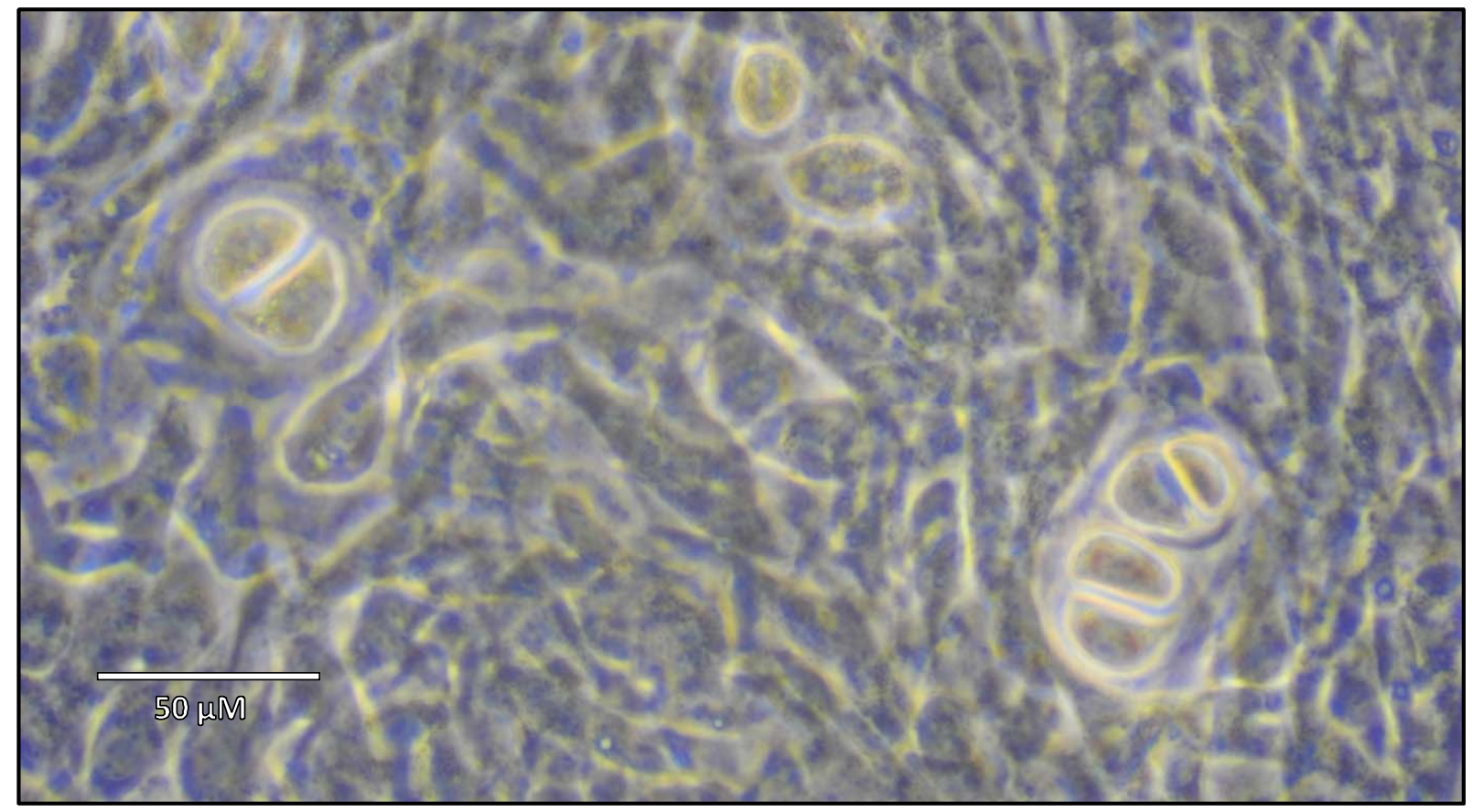

Abbildung 5: Chondrozytennester in einer P1-Kultur nach 8 Tagen, dargestellt bei 400-facher Vergrößerung im Lichtmikroskop. 
Um die Abläufe bei der Zellisolation fließend zu gestalten, wurden die Tierkörper der Spenderhunde vor der Knorpelzellgewinnung bis zu 24 h bei $7{ }^{\circ} \mathrm{C}$ gelagert. Diese Verzögerung hatte, wie auch in anderen Studien, keine erkennbaren Auswirkungen auf die Lebensfähigkeit der Zellen (RAl et al. 2009). Beim Menschen gelten Zeitintervalle zwischen Tod und Knorpelzellgewinnung von bis zu $48 \mathrm{~h}$ als akzeptabel (KAPS et al. 2004), da sich die Zellen in einem zum restlichen Körper abgeschlossenen Kompartiment befinden und sehr widerstandsfähig sind (ALIBEGOVIC 2014). Das Protokoll zur Zellisolation orientierte sich an einer Vorschrift zur Isolierung von humanen Chondrozyten (KAPS et al. 2004), welches bereits in anderen Studien mit caninen Chondrozyten erfolgreich zur Anwendung kam (RAl et al. 2009).

Eine wichtige Modifikation des Protokolls lag in der Verwendung verschiedener Medienzusätze zur Steigerung der Matrixbildung und Erhalt des Phänotyps bei der Anzucht der Zellen. Zu diesen Medienzusätzen gehören Ascorbinsäure, Glucose und Insulin. Ascorbinsäure ist Cofaktor für die Synthese von Kollagen II und damit essenziell für die Bildung einer gesunden ECM. Glucose dient als Baustoff für Glykosaminoglykane und ist außerdem ein wesentlicher Energielieferant für Knorpelzellen, kann jedoch ohne Insulin nur mangelhaft in die Zellen aufgenommen werden (CIGAN et al. 2013). Erst nach Zugabe von Ascorbinsäure, Glucose und Insulin kommt es zum Auftreten von Chondrozytennestern in den Kulturen und deutlicher Matrixbildung, weshalb wir davon ausgehen, dass die Zusätze wesentlich zur Zelldifferenzierung in den Kulturen beigetragen haben.

Die Zellansätze aller Spender wurden separat vermehrt, um subvitale Kulturen auszuschließen, und schließlich bei $-20^{\circ} \mathrm{C}$ in der Knorpelzellbank gelagert. Eine Kryokonservierung mit $5 \%$ DMSO hat keine Auswirkung auf den Differenzierungsstatus der Chondrozyten, kann allerdings die Proliferation und Überlebensrate negativ beeinflussen (RENDAL-VÁZQUEZ et al. 2001). Wie wir durch den Vergleich der Zellzahlen vor dem Einfrieren und nach dem Auftauen ermitteln konnten, kam es durch die Kryokonservierung zu Zellverlusten von bis $\mathrm{zu} 30 \%$. Damit unterscheiden sich die Überlebensraten der Kryokonservierung in unserem Modell nicht von der Überlebensrate in anderen Modellen (RENDAL-VÁZQUEZ et al. 2001).

Insgesamt präsentieren wir in dieser Studie ein leicht umsetzbares Protokoll zur Isolation, Kryokonservierung und Anzucht von caninen Chondrozyten mit einer hohen Zellausbeute. Das Protokoll dient der Erstellung von 2D-Kulturen von caninen Chondrozyten, welche für die Untersuchung von physiologischen zellulären Prozessen wie Signaltransduktion, Teilung und Zellmetabolismus geeignet sind und als Modell für Gelenkserkrankungen verwendet werden können. 


\subsection{IL-stimulierte canine Chondrozyten als Osteoarthrosemodell}

$\mathrm{OA}$ ist eine Krankheit mit einer komplexen Pathogenese, welche alle Strukturen des Gelenks involviert (HASEEB und HAQQI 2013). Auf Grund der multifaktoriellen Genese existieren verschiedene Unterformen der Krankheit, deren Entstehung nicht an einen gemeinsamen Mechanismus gebunden ist, sondern individuellen Mustern folgt (WANG et al. 2015; BERENBAUM 2013). Dementsprechend ist es kaum möglich, ein Modellsystem zu finden, welches alle Facetten der Krankheit wiedergibt. In dieser Studie kommt ein in vitro Modell zum Einsatz, welches vor allem die inflammatorischen Aspekte der Krankheit thematisiert. Basis für dieses Modell ist eine Stimulation der Chondrozyten mit dem proinflammatorischen Zytokin IL-1 $\beta$.

Dieses Zytokin bewirkt unter natürlichen Bedingungen eine Steigerung der katabolen Stoffwechselwege bei gleichzeitiger Schwächung der anabolen Stoffwechselwege und führt schließlich zum Schlüsselereignis der $\mathrm{OA}$, der irreversiblen Zerstörung der ECM (WOJDASIEWICZ et al. 2014). Vor allem im frühen Stadium der OA produzieren die Synovialozyten der Gelenkskapsel große Mengen an IL-1 $\beta$ (TETLOW et al. 2001), welches über die Synovia zu den Chondrozyten diffundiert. Daher stellte die externe Zugabe von IL-1 $\beta$ ins Zellkulturmedium den Zustand im Gelenk zum Beginn der OA nach (Grad I bis II). Früher wurde IL-1 $\beta$ neben TNF- $\alpha$ als wichtigster Auslöser der ersten osteoarthrotischen Veränderungen angesehen (FERNANDES et al. 2002; WESTACOTT und SHARIF 1996). Inzwischen konnte jedoch gezeigt werden, dass die Rolle von IL-1 $\beta$ zu Beginn der Krankheit weniger wichtig ist als bisher angenommen (SANDY et al. 2015). So geht man inzwischen davon aus, dass auch andere Zytokine wie Interleukin-17 oder Interleukin-6 einen wesentlichen Beitrag zum Krankheitsbeginn leisten (WOJDASIEWICZ et al. 2014). Dennoch ist die Anwendung von IL-1 $\beta$ in 2D- und 3D-OA Modellen bei Menschen (HURST et al. 2009; CURTIS et al. 2002b) und Hunden (DYCUS et al. 2013; RAl et al. 2008; KUROKI et al. 2005; COOK et al. 2000) gut etabliert. In vitro Studien konnten zeigen, dass auch eine alleinige Stimulation mit dem Zytokin ein Enzymmuster hervorruft, welches dem natürlichen Krankheitsverlauf weitestgehend entspricht (RAl et al. 2008; COOK et al. 2000). Darüber hinaus steigert IL-1 $\beta$ die Produktion anderer Zytokine, wie z.B. Interleukin-6 (GUERNE et al. 1990) und könnte dadurch ebenfalls den Krankheitsprozess vorantreiben.

Viele in vitro Modelle arbeiten mit überphysiologischen Konzentrationen von bis zu $100 \mathrm{ng} / \mathrm{ml}$ IL-1 $\beta$ (KUROKI et al. 2005) oder langen Stimulationszeiten von bis zu 20 Tagen (COOK et al. 2000). Im gewählten Modell wird bereits bei $10 \mathrm{ng} / \mathrm{ml} \mathrm{IL-1 \beta}$ über $24 \mathrm{~h}$ eine Expression von Markern initiiert, welche in ähnlicher Form in den Gelenken von an OA erkrankten Hunde auftritt (CLEMENTS et al. 2009). Diese Dosis ist zwar im Vergleich zu anderen Studien niedrig, entspricht aber dennoch der fünffachen Menge der natürlichen Konzentration von IL-1 $\beta$ in der 
Synovia von caninen ostoarthrotischen Gelenken (FUJITA et al. 2005). Im vorliegenden Modell erhöhen die Chondrozyten unter Einfluss von IL-1 $\beta$ die Genexpression und Produktion aller ausgewählten Marker und reduzieren die Bildung matrixschützender Enzyme wie TIMP-2. Nur die Expression von ADAMTS-5 bleibt trotz Stimulation mit IL-1 $\beta$ unverändert. Diese Beobachtung ist in Übereinstimmung mit anderen Studien (CURTIS et al. 2002b) und zeigt erneut, dass ADAMTS-5 im Gegensatz zu ADAMTS-4 rein konstitutiv exprimiert wird (TORTORELLA et al. 2001). Zusammenfassend lässt sich sagen, dass im vorgestellten 2D-Zellkulturmodell die Dosis von $10 \mathrm{ng} / \mathrm{ml} \mathrm{IL}-1 \beta$ über $24 \mathrm{~h}$ ausreichend ist, um typische Abläufe der caninen OA zu initiieren.

Damit wird in dieser Arbeit ein simples und dennoch realistisches Modell für die canine OA präsentiert, welches in Zukunft zur näheren Untersuchung der Pathogenese und zur Entwicklung neuer Therapieoptionen von großem Nutzen sein kann. Inwiefern sich dieses Modell auch auf die Situation in der humanen OA übertragen lässt, bleibt abzuwarten. Tatsächlich ähneln sich viele pathologische Abläufe bei Hund und Mensch. Bei beiden sind mechanische und inflammatorische Aspekte im Krankheitsverlauf beteiligt, wie auch eine Aktivierung des Immunsystem und eine Beteiligung des Komplementsystems (FRYE et al. 2016; MALEMUD 2015). Zudem ähneln sich die Expressionsmuster von Proteasen und Matrixmolekülen im Knorpel vor allem im späten Stadium der Krankheit bei Menschen und Hunden (CLEMENTS et al. 2006). Doch konnten auch speziesabhängige Unterschiede nachgewiesen werden. So scheinen einige Gene, z.B. TIMP-2, bei Menschen rein konstitutiv exprimiert zu sein (KEVORKIAN et al. 2004), wogegen sie beim Hund induzierbar sind (CLEMENTS et al. 2009).

\section{$5.3 \quad$ TGF $-\beta$ als Gegenspieler von IL-1 $\beta$}

Diese Studie beleuchtet zum ersten Mal die Wirkung von TGF- $\beta$ auf typische Entzündungsmarker in einem in vitro Modell der caninen OA. Zur Untersuchung dosisabhängiger Effekte kamen Konzentrationen von 1 und $10 \mathrm{ng} / \mathrm{ml}$ über $24 \mathrm{~h}$ zum Einsatz. Dabei handelt es sich, wie kürzlich bewiesen wurde, um physiologische bis supraphysiologische Konzentrationen. Die Konzentrationen von TGF- $\beta$ in der Synovia beim Hund liegen im Bereich von $1 \mathrm{ng} / \mathrm{ml}$ und verdoppeln sich im Zuge einer OA (NEUMANN und LAUENSTEIN-BOSSE 2018).

In unserem Modell reduziert TGF- $\beta$ dosisabhängig die IL-induzierte Genexpression von MMP-3, COX-2 und iNOS, die damit korrelierende Produktion von PGE und NO sowie das MMP-3/TIMP-2 Verhältnis. Diese Beobachtung lässt sich durch die direkte Interaktion von TGF- $\beta$ und IL-1 $\beta$ erklären. So bewirkt TGF- $\beta$ im Zusammenspiel mit IL-1 $\beta$ nicht nur einen Schutz der ECM über eine veränderte Expression von matrixdestruktiven und -protektiven 
Genen (BAUGÉ et al. 2014), sondern auch einen Rückgang der IL-Rezeptoren und antagonisiert damit zusätzlich die Signalübertragung von IL-1 $\beta$ selbst (RÉDINI et al. 1993; HARVEY et al. 1991).

Unter TGF- $\beta$ allein besteht eine ähnliche Tendenz, jedoch fallen die Effekte im Vergleich zu den Effekten bei einer simultanen Inkubation mit IL-1 $\beta$ schwächer bis nicht signifikant aus. So sinkt ebenfalls die Expression von iNOS sowie das MMP-3/TIMP-2 Verhältnis dosisabhängig, wogegen die Produktion von NO und PGE unbeeinflusst niedrig bleibt. Nur die Expression der COX-2 steigt dosisabhängig signifikant an. Da in dieser Studie jedoch die Entwicklung der COX-2 Expression und die PGE Produktion oft nicht übereinstimmt, ist davon auszugehen, dass die PGE Produktion in diesem Modell über andere Mechanismen beeinflusst wird und eine Expressionsänderung der COX-2 keine nennenswerte Auswirkung hat. Zusammenfassend zeigen unsere Untersuchungen, dass TGF- $\beta$ beim Hund weitreichende vorteilhafte Effekte auf osteoarthrotische Marker hat und bei einem gemeinsamen Auftreten mit IL-1 $\beta$ als dessen Gegenspieler agiert.

Nicht alle Studien mit TGF- $\beta$ kommen zu so einem eindeutigen Ergebnis. So kam es in früheren Studien an Chondrozyten von Menschen und Kaninchen oft zu inkonsistenten Ergebnissen, welche eine schädliche Wirkung von TGF- $\beta$ im Krankheitsverlauf nicht ausschließen (FAWTHROP et al. 1997; MEJIERS et al. 1994; PUJOL et al. 1991). Neuere Forschungsergebnisse legen nahe, dass TGF- $\beta$ nur in einem kurzen Zeitraum und engen Dosisbereich vorteilhafte Effekte hat (ZHAl et al. 2015). Kurze Inkubationszeiten vermitteln über die Activin-like Rezeptorkinase-5 eine Phosphorylierung der R-Smad-2 und -3 und damit die Expression chondroprotektiver Gene. Längere Inkubationszeiten hingegen bewirken eine Reduktion der Activin-like Rezeptorkinase-5 bei gleichzeitiger Induktion von dem inhibitorischen SMAD-7. Ohne Activin-like Rezeptorkinase-5 weicht die Signaltransduktion zur Activin-Rezeptorkinase-1 aus, welche über die R-SMAD-1, -5 und -8 zu einer Betonung der destruktiven Wirkungen von TGF- $\beta$ führen (BAUGÉ et al. 2014). Bisher ist nicht genau bekannt, in welchem Dosisbereich und unter welchen Kultivierungsbedingungen TGF- $\beta$ vorteilhaft ist. So scheint sich unter anderem die Kulturform (2D vers. 3D) (DEMOORFOSSARD et al. 1999) und der Einsatz von Serum (FAWTHROP et al. 1997) auf die Untersuchungsergebnisse auszuwirken. Da TGF- $\beta$ in dieser Studie nur über einen kurzen Zeitraum von $24 \mathrm{~h}$ eingesetzt wurde, sind die positiven Effekte wahrscheinlich der kurzen Inkubationsperiode zuzuschreiben. An Hand unserer Ergebnisse können wir schlussfolgern, dass in caninen 2D-Modellen eine Dosis von $10 \mathrm{ng} / \mathrm{ml}$ über $24 \mathrm{~h}$ keinen schädlichen Einfluss auf den Knorpelmetabolismus hat. Diese Beobachtung ist von großer Bedeutung, da TGF- $\beta$ in anderen caninen Kulturen als chondrogenes Differenzierungsmedium zum Einsatz kommt (CSAKI et al. 2007). 
Beim Menschen ist ein fortgeschrittenes Alter einer der wichtigsten Risikofaktoren für OA. Da das Knorpelgewebe älterer Menschen mechanischen Stress schlechter kompensieren kann, kommt es im Falle einer Fehlbelastung oder Schädigung zu rapideren Krankheitsverläufen als bei jungen Menschen. Neben einer Veränderung der biomechanischen Eigenschaften der ECM liegt die Ursache wahrscheinlich in einer verminderten Ansprechbarkeit der Chondrozyten auf Wachstumsfaktoren wie Insulin-like Growth Faktor-1 oder TGF- $\beta$ (ANDERSON und LOESER 2010). So exprimieren Menschen im Alter geringere Mengen des TGF- $\beta$ Rezeptors. Zusätzlich verliert TGF- $\beta$ seine protektiven Wirkungen durch die Verschiebung der Signalwegen von R-Smad-2/-3 zu R-Smad-1/-5/-8 (VAN DER KRAAN 2014; BLANEY DAVIDSON et al. 2005). Obwohl die verwendeten Chondrozyten vor allem von älteren Hunden gewonnen wurden, ist in unserem Modell keine verminderte Ansprechbarkeit auf TGF- $\beta$ festzustellen. Daher lässt sich vorsichtig die Hypothese aufstellen, dass in Hunden die altersabhängigen Veränderungen der Signaltransduktion ausbleiben und TGF- $\beta$ auch in älteren Tieren effektiv ist. Zusammenfassend zeigen die Untersuchungen, dass TGF- $\beta$ beim Hund weitreichende vorteilhafte Effekte auf osteoarthrotische Marker hat. Auf Basis dieser Ergebnisse sollte man TGF- $\beta$ eine größere Bedeutung als Angriffspunkt für Therapeutika gegen $O A$ auch beim älteren Hund zuschreiben.

\subsection{Fettsäuremetabolismus der Chondrozyten}

Als avaskuläres Gewebe mit einer engmaschigen, anionischen ECM unterliegt Knorpel einer stark limitierten Versorgung mit Nährstoffen. Die Ernährung der Zellen erfolgt hauptsächlich über die Diffusion aus der Synovia (WANG et al. 2013b) und zu geringem Anteil über den anliegenden subchondralen Knochen (PAN et al. 2009). In der Synovia werden Fettsäuren auf Grund ihres hydrophilen Charakters an große Proteine wie Albumin gebunden oder als Triglyceride mittels Lipoproteinen transportiert. Vor dem Eindringen in die ECM löst sich die Fettsäure von ihrem Transportprotein und diffundiert durch das engporige Netzwerk der ECM (ARKILL und WINLOVE 2006). Um die natürlichen Gegebenheiten zu imitieren, kam in dieser Studie fetales Kälberserum (FCS) zum Einsatz. Das darin enthaltene Albumin und die darin enthaltenen Lipoproteine ermöglichen den Fettsäuren, zu den Chondrozyten in der Zellkultur zu diffundieren. Demensprechend stellt das Zellkulturmedium mit 5 \% FCS die Synovia dar und die Monolayer-Zellkultur die Knorpelschicht der Gelenke.

Wegen des limitierten Zugriffs auf Lipide hat Knorpelgewebe eine einzigartige Fettsäurezusammensetzung. Wie Fettsäureanalysen vom Knorpel verschiedener Spezies zeigen, haben die n-9 Fettsäuren Ölsäure und Meadsäure, die n-6 Fettsäuren Linolsäure (LA) und Arachidonsäure (AA), sowie die gesättigten Fettsäuren Palmitinsäure und Stearinsäure den größten Anteil (CLELAND et al. 1995; XU et al. 1994; ADKISSON et al. 1991). Allein 
Palmitin-, Öl- und Linolsäure machen beim Menschen $85 \%$ der Gesamtfettsäuren aus (LIPPIELLO et al. 1991). Diese Beobachtung konnten wir in dem vorgestellten Modell nur teilweise bestätigen. So entspricht das Fettsäuremuster der caninen Knorpelzellen ohne Supplementierung zwar weitestgehend dem Fettsäuremuster des Knorpels anderer Spezies, jedoch weisen die Zellen einen relativ geringen Gehalt an ALA (0,5\%) und AA (2\%) und einem im Vergleich hohen Gehalt an EPA $(0,3 \%)$ und DHA (1,2\%) auf. Das Verhältnis von n-6 zu n-3 beträgt 1,4:1 und ist damit schon vor einer Supplementierung mit EPA oder DHA recht vorteilhaft. Zudem machen Palmitin-, Öl- und Linolsäure nur 45 \% der Gesamtfettsäuren aus. Für diese Diskrepanz gibt es zwei mögliche Erklärungen. Zum einen ist bekannt, dass Knorpel nicht nur intrazelluläre Lipide enthält, sondern die Zellen der oberflächlichen Schichten von einem Mantel aus extrazellulären Lipiden umgeben werden (MANSFIELD und WINLOVE 2017). Da die Chondrozytenkulturen als Monolayer nur geringe Anteile an ECM enthalten, wäre es möglich, dass im Modell nur geringe Mengen an extrazellulären Lipiden vorkommen und damit die Zusammensetzung der Lipide anders ausfällt, als bei der Analyse ganzer Gewebsstücken. Zum anderen wurde im Gegensatz zu anderen Studien (WANN et al. 2010; HURST et al. 2009; ZAINAL et al. 2009; CURTIS et al. 2002a; CURTIS et al. 2002b) FCS anstelle von bovinem Serumalbumin eingesetzt, da bovines Serumalbumin zu einer erhöhten Zytokinfreisetzung führen kann (WANN et al. 2010; ZHAO et al. 2009) und somit eventuell die Ergebnisse dieser Studie beeinflusst hätte. Ein Nachteil bei der Nutzung von FCS besteht in den darin vorhandenen Fettsäuren, welche den Fettsäuremetabolismus der Chondrozyten ebenfalls beeinflussen. Tatsächlich enthält das genutzte FCS relativ hohe Mengen an EPA und DHA und es kommt bei dem Wechsel von $10 \%$ zu $5 \%$ FCS im Kulturmedium zu Veränderung des Fettsäuremusters. Daher ist davon auszugehen, dass das verwendete FCS einen Einfluss auf die Ausgangszusammensetzung der Fettsäuren im Modell hatte. Dies entspricht jedoch zumindest in der Theorie den natürlichen Gegebenheiten, da sich auch bei einer Gabe von Fischöl zusätzlich zum handelsüblichen Futter die Hintergrunddiät auf das Fettsäuremuster im Gelenk auswirkt (MANTZIORIS et al. 1994).

Die Dosis von $10 \mu \mathrm{M}$ DHA, EPA oder AA über 8 Tage liegt wahrscheinlich nicht über den Konzentrationen, die im Gelenk unter natürlichen Bedingungen erreicht werden können. Gesunde Hunde mit einer Ernährung ohne zusätzliche Fischölgaben weisen im Blut Konzentrationen von 50 MM EPA bzw. DHA auf (HALL und JEWELL 2012). Da es sich bei der Synovia um ein Ultrafiltrat des Plasmas handelt, ist davon auszugehen, dass die Fettsäurekonzentration im Blut einen wesentlichen Einfluss auf die Fettsäurekonzentration in der Synovia hat. Tatsächlich konnte durch eine Supplementierung von langkettigen n-3 PUFAs bei Pferden ein Anstieg der EPA und DHA Konzentration in der Synovia hervorgerufen werden (ROSS-JONES et al. 2016). Bekannt ist außerdem, dass beim Menschen das Fettsäuremuster 
der Synovia weitestgehend dem Fettsäuremuster des Blutes entspricht (MOGHADDAMI et al. 2015). Leider existieren derzeit keine Publikationen, welche die erreichbare Endkonzentration von EPA und DHA in der Synovia untersuchen. Im Blut hingegen wurde die Steigerung der Fettsäurekonzentration, welche durch eine n-3 PUFA-supplementierte Diät erreichbar ist, bereits erforscht. So kam es nach einer 90-tägigen Fütterung mit einem Futter, welches 1-3\% EPA und DHA in der Trockenmasse enthält, im Blut von osteoarthrotischen Hunden zu einer 20-fachen Steigerung von EPA und 6-fachen Steigerung von DHA (FRITSCH et al. 2010a). Andere Autoren beschreiben bei einer Fütterung von 0,2 ml Fischöl/kg Körpergewicht/Tag über 112 Tage eine 6-fache Steigerung von EPA und eine 2-fache Steigerung von DHA im Blut (BARROUIN-MELO et al. 2016). Im Zuge der OA kommt es zusätzlich zu einem erhöhten Lipidgehalt in der Synovia (KOSINSKA et al. 2016; DAMYANOVICH et al. 1999). Dies ist wahrscheinlich bedingt durch die bessere Nährstoffversorgung wegen der Gefäßeinsprossung ausgehend vom subchondralen Knochen sowie der Auflockerung des dichten Netzwerkes der ECM durch Matrixproteasen (PAN et al. 2012; LOTKE und GRANDA 1972). Zusammenfassend lässt sich schlussfolgern, dass relativ zu den Blutspiegeln gesunder Hunde ohne Fettsäuresupplementierung eine 5-fach geringere Konzentration an EPA und DHA zur Anwendung kam. Im Zuge einer $O A$ und bei einer Fütterung fischölreicher Diäten sind wahrscheinlich sogar höhere Spiegel im Blut und damit im Gelenk zu erwarten. Daher könnte die Fettsäurekonzentration im Modell sogar unterhalb der Fettsäurekonzentration liegen, die unter natürlichen Bedingungen im Gelenk erreichbar ist. Im Gegensatz zu der Mehrzahl anderer Studien mit bis zu 30-fach höheren Fettsäuredosen (ZAINAL et al. 2009; CURTIS et al. 2002a; CURTIS et al. 2002b) wird damit der Einfluss einer relativ geringen Fettsäuredosis über einen längeren Zeitraum geprüft. Dies ermöglicht eine bessere Vergleichbarkeit zur Situation im caninen Gelenk, da der Gehalt an Fischöl in Ergänzungsfuttermitteln und Spezialdiäten für Hunde nachweislich gering ist (BAUER 2007). Diese Studie liefert somit einen Beitrag zur Frage, ob eine Langzeitsupplementierung einer niedrigen Dosis zu ähnlichen Effekten führt wie die kurze Gabe hoher Dosen an EPA und DHA.

Die n-3 PUFA ALA beeinflusst das n-6 zu n-3 Verhältnis ebenfalls positiv und ist im Vergleich zu Fischöl deutlich kostengünstiger (LOPEZ 2012). Eine Überlegung war es daher, die n-3 PUFA ALA in die Studie einzubeziehen. Theoretisch sind Hunde in der Lage, ALA in EPA zu konvertieren, in Realität erfolgt die Umwandlung jedoch nur in einer sehr geringen Rate (BAUER 2007; HARRIS et al. 2007). Hinzu kommt, dass deutlich höhere Mengen an ALA nötig sind, um ähnliche Effekte wie mit DHA und EPA zu erzielen (ZAINAL et al. 2009; BAUER 2007). Da dosisabhängige Nebenwirkungen von n-3 Fettsäuren wie Durchfall oder Erbrechen auftreten können (LENOX und BAUER 2013), wäre demnach eine Supplementierung mit der effektiven Dosis von ALA für die Patienten mit einem Risiko für 
gastrointestinale Nebenwirkungen verbunden. Auch aus anderen Studien ergeht die Empfehlung, die Diäten direkt mit EPA und DHA zu supplementieren und nicht auf eine Umwandlung aus ALA zu vertrauen (MEHLER et al. 2016; BAUER 2008). In dieser Studie entscheiden wir uns daher für die direkte Zugabe von EPA und DHA und nicht ALA.

Um den Fettsäureeinbau in die Chondrozyten zu dokumentieren, wurde in Vorversuchen nach 4, 6 und 8 Tagen sowie nach Zugabe von 0, 10, 20 und $50 \mu \mathrm{M} \mathrm{AA,} \mathrm{EPA} \mathrm{und} \mathrm{DHA} \mathrm{das}$ Fettsäuremuster der Zellen gaschromatographisch analysiert. In Übereinstimmung mit anderen in vitro Studien (ZAINAL et al. 2009; CURTIS et al. 2002a) kam es zu einer konzentrationsabhängigen Aufnahme aller untersuchten Fettsäuren. Im zeitlichen Verlauf war eine deutliche Zunahme von EPA, DHA und AA zwischen dem ersten und dem vierten Tag festzustellen, die gegen Ende der Untersuchungsperiode zunehmend abflacht. Der Gesamtgehalt an Fettsäuren hingegen steigt kontinuierlich an. Diese Beobachtung entspricht den Ergebnissen anderer Studien, in denen die Zunahme der Fettsäurekonzentration von EPA, DHA und AA bereits 8 Stunden nach Beginn der Supplementierung stagniert (ZAINAL et al. 2009; CURTIS et al. 2002a; NAGAO et al. 1991). Da sich diese Studie auf eine Langzeitsupplementierung von Fettsäuren konzentriert, wurden zwischen Studienbeginn und den ersten vier Tagen keine gaschromatographischen Untersuchungen durchgeführt. Andere Studien untersuchen den Fettsäureeinbau dieser PUFAs nur über eine Periode von $48 \mathrm{~h}$ (ZAINAL et al. 2009; CURTIS et al. 2002a; NAGAO et al. 1991). Es ist nicht auszuschließen, dass es in ähnlichen Modellen ebenfalls zu einem zeitabhängigen Abfall von EPA, DHA und AA kommt. Eine mögliche Erklärung ist, dass die Chondrozyten die bereits aufgenommenen PUFAs metabolisieren. Tatsächlich wurde ein zeitabhängiger Anstieg von Docosapentaensäure (DPA) in EPA-supplementierten Kulturen festgestellt. Übereinstimmend mit anderen Autoren sind canine Chondrozyten somit in der Lage, EPA mittels Elongase in DPA umzuwandeln. Da DPA in der Theorie mit Hilfe der $\triangle 6$-Desaturase zu DHA konvertiert werden kann, könnte DPA im Körper als zirkulierendes Reservoir für DHA genutzt werden (BAUER 2007). Bei Menschen wurde allerdings gezeigt, dass dieser Syntheseweg für die Bildung von DHA kaum Bedeutung hat (BRENNA et al. 2009). Da es in unserem Modell trotz des hohen Gehalts an DPA (6 \%) nur zu einem geringen Anstieg von DHA kommt, ist davon auszugehen, dass auch Hunde kaum in der Lage sind, DPA in DHA umzuwandeln. Kulturen, welche mit DHA supplementiert wurden, zeigen einen zeitabhängigen Anstieg von DPA und EPA. Eine Retrokonversion von DHA zu EPA scheint demnach beim Hund, genau wie bei Ratte und Mensch (CONQUER und HOLUB 1997), stattzufinden. 


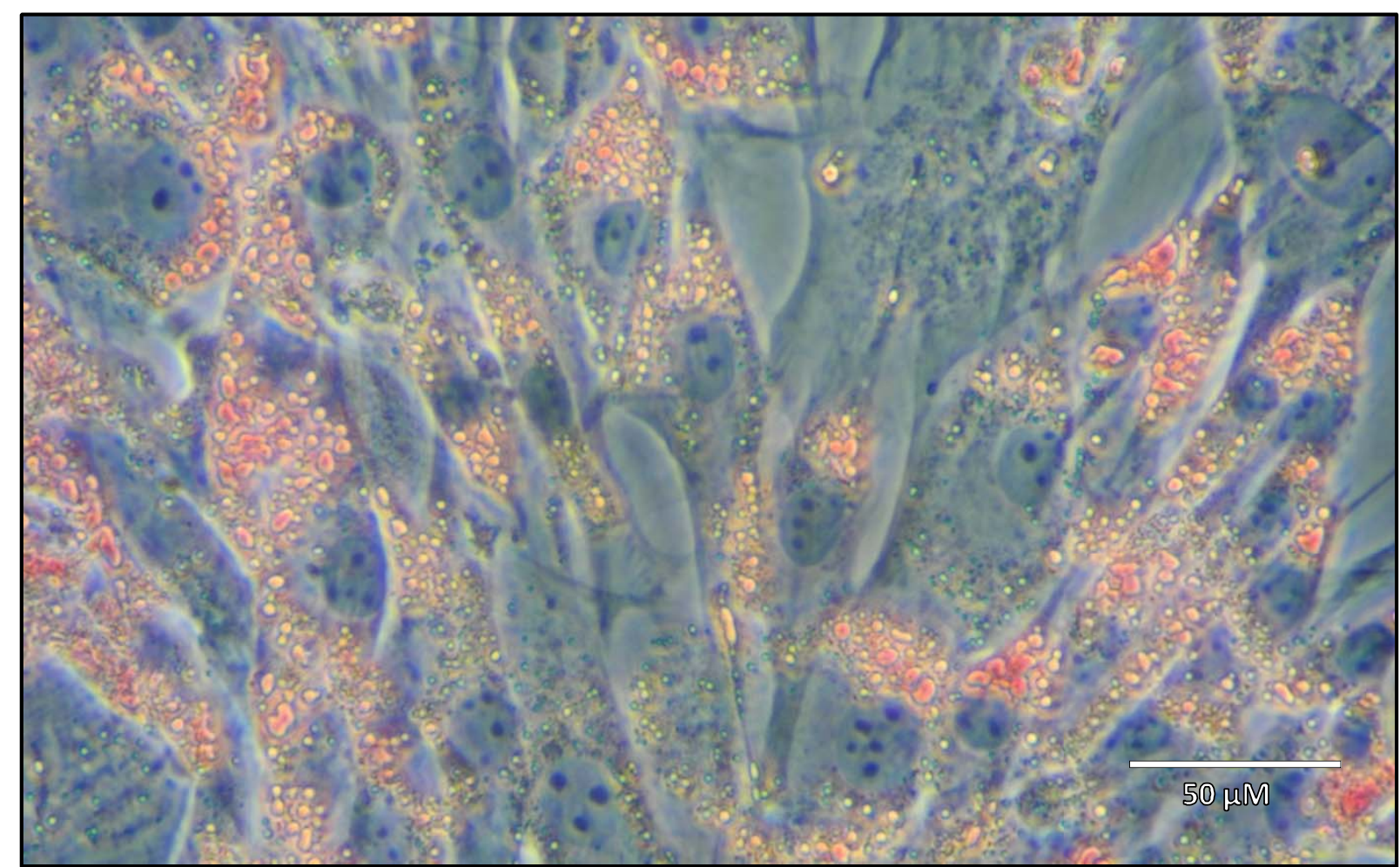

Abbildung 6: Lipidvakuolen in Chondrozyten nach einer Supplementierung des Mediums mit 200 M ALA über 8 Tage, dargestellt mittels Öl Rot O Färbung bei 400-facher Vergrößerung im Lichtmikroskop

Um eine toxische Wirkung der Fettsäuren abzuschätzen, wurden in Vorversuchen die Kulturen mit bis zu $200 \mu \mathrm{M}$ LA und ALA über 8 Tagen behandelt. Trotz der hohen Fettsäurekonzentrationen waren keine Veränderungen in Proliferation oder Vitalität zu beobachten. Dies sehen auch andere Autoren, welche bei $500 \mu \mathrm{M}$ LA, ALA und Ölsäure keine toxischen Wirkungen feststellen können (NAGAO et al. 1991). Im Vorversuch zum Fettsäureeinbau kam es jedoch in den Kulturen, welche mit 20 und $50 \mu \mathrm{M}$ DHA behandelt wurden, zu einem erhöhten Zellsterben. Bei Brustkrebszellen ist bekannt, dass DHA eine Apoptose der Zellen induzieren kann (VANDERSLUIS et al. 2017). Diese Wirkung wurde zumindest teilweise mit einer stattgefundenen Lipidperoxidation begründet (GONZALEZ et al. 1993). Obwohl erhöhte Mengen an Fischöl in der Nahrung mit der Gefahr eines Auftretens von Lipidperoxidationsprodukten einhergehen, führen n-3 PUFAs in vivo zu einer Aktivierung des antioxidativen Schutzsystems (BARROUIN-MELO et al. 2016; KEARNS et al. 1999). Daher ist es wahrscheinlich, dass die beobachteten schädlichen Effekte bei dem Einsatz von hohen Konzentrationen DHA für die Zellvitalität in vivo keine Relevanz haben. 


\subsection{Fettsäuren als Therapieoption bei der caninen OA}

Bei in vitro Studien an bovinen und humanen Chondrozyten bewirkt die Zugabe von n-3 PUFAs eine Reduktion von inflammatorischen Markern wie Matrixproteinasen, proinflammatorischen Zytokinen und Cyclooxygenasen (HURST et al. 2009; ZAINAL et al. 2009; CURTIS et al. 2002a; CURTIS et al. 2002b). Darüber hinaus kam es in bovinen Explantkulturen unter Einfluss von EPA und DHA zu einer Reduktion des Abbaus der Glykosaminoglykane (WANN et al. 2010). Eine Supplementierung mit n-6 PUFAs hingegen führt, wie erwartet, zu keiner Veränderung oder sogar einem Anstieg der inflammatorischen Marker (HURST et al. 2009; ZAINAL et al. 2009; CURTIS et al. 2002a; CURTIS et al. 2002b). In caninen Studien kommt es jedoch teilweise zu abweichenden Ergebnissen. In einer caninen Studie konnte bei OA kein Unterschied zwischen den Effekten von Fischöl und dem Placebo Maiskeimöl auf oxidativen Stress festgestellt werden (BARROUIN-MELO et al. 2016). In einer anderen caninen Studie führte die Fütterung von Fischöl in Vergleich zu Maiskeimöl zu keiner stärkeren Verbesserung der OA Symptome (HIELM-BJÖRKMAN et al. 2012). Auf Basis dieser in vitro Studien lässt sich die Hypothese aufstellen, dass Maiskeimöl zu ähnlich positiven Effekten führt wie Fischöl. Maiskeimöl enthält vor allem die n-6 PUFA LA, welche von Hunden zur n-6 PUFA AA konvertiert werden kann (BAUER 2007). Die vorgestellte Studie unterstützt diese Hypothese und bietet darüber hinaus eine Erklärung für den fehlenden Unterschied zwischen Fischöl und Maiskeimöl, denn auch in diesem Modell hatte nicht nur die n-3 PUFA EPA sondern auch die n-6 PUFA AA vereinzelt positive Effekte auf einige der untersuchten Marker. So wird die Expression von iNOS und die damit einhergehende Produktion von NO durch AA stärker herabgesetzt als durch EPA oder DHA. Darüber hinaus führt AA als einzige Fettsäure in unserer Studie zu einer signifikanten Reduktion der MMP-3 Expression. Da es sich bei MMP-3 zusätzlich um einen Aktivator von Pro-IL-1 $\beta$, Pro-TNF sowie verschiedenen Pro-MMPs handelt (CUI et al. 2017), ist es wahrscheinlich, dass diese Reduktion eine weitreichende Auswirkung auf die gesamte Entzündungskaskade im gewählten Modell hat. Neben diesen positiven Effekten sind in dieser Studie allerdings auch erhebliche negative Wirkungen von AA zu verzeichnen, unter anderem eine gesteigerte Genexpression von der Aggrecanase ADAMTS-5 und eine extrem erhöhte Produktion von PGE.

DHA entfaltet seine matrixprotektive und entzündungslösende Wirkung hauptsächlich über die Bildung von speziellen Lipidmediatoren, wie zum Beispiel die D-Serie der Resolvine und Protektine (WEYLANDT et al. 2012). Im vorgestellten Modell hat eine Supplementierung mit DHA auf keinen der untersuchten Marker eine signifikante Wirkung. Auch andere Autoren kommen zu dem Ergebnis, dass DHA im Vergleich zu EPA eine deutlich geringere Effizienz hat (WANN et al. 2010; ZAINAL et al. 2009). Dabei konnte in einer Studie beobachtet werden, dass die Effizienz von DHA initial besser ist als die von EPA, aber innerhalb der ersten $120 \mathrm{~h}$ 
deutlich nachlässt (WANN et al. 2010). Da in unserer Arbeit die Wirkung von DHA erst nach 8 Tagen evaluiert wird, ist es möglich, dass DHA zu Beginn der Studienperiode effizienter wirkt, die Wirkung jedoch bis zum 8. Tag verloren geht. Eine Erklärung zu diesem Phänomen fehlt bisher. Es ist bekannt, dass DHA im Gegensatz zu EPA nicht von der COX-2 umgesetzt werden kann und somit nicht mit AA konkurriert. Daher ist davon auszugehen, dass DHA keinen direkten Einfluss auf die PGE2 Produktion hat, wogegen EPA zu einem Abfall von PGE2 und einem Anstieg von PGE3 führt (SMITH et al. 2011). Da PGE2 eine synergistische Wirkung auf andere Marker in der OA hat, unter anderem iNOS und MMPs (LI et al. 2009; ATTUR et al. 2008), ist denkbar, dass durch die fehlende Beeinflussung der PGE2 Produktion durch DHA auch der Einfluss auf andere Marker ausbleibt. Leider kann in diesem Modell keine Aussage zu dieser Hypothese getroffen werden, da auf Grund einer Kreuzreaktion in dem verwendeten ELISA nicht zwischen PGE2 und PGE3 unterschieden werden kann. In dieser Untersuchung kam es demnach weder bei der Gabe von EPA noch bei der Gabe von DHA zu einer Veränderung der PGE Produktion.

NSAIDs sind die häufigsten verordneten Medikamente in der caninen OA (BOUND et al. 2011). Sie verhindern über die Hemmung der COX-2 eine Bildung von PGE2 und wirken somit effektiv gegen Schmerz und Entzündung im Gelenk (SMITH et al. 2011). Um die Effizienz der Fettsäuren besser abschätzen zu können, kam in der vorgestellten Studie das NSAID Ibuprofen zum Einsatz. Die Dosis von Ibuprofen wurde so gewählt, dass es zu einer Reduktion der PGE Produktion von 50 \% kam. Ibuprofen kommt zwar beim Hund nicht zur Verwendung (CLINIPHARM/CLINITOX 2018a), ist aber im Gegensatz zu Carprofen und Meloxicam ein nicht-selektiver COX 2 Inhibitor mit einer mittleren Wirksamkeit (MITCHELL und WARNER 1999) und somit ein guter Vertreter dieser Wirkstoffklasse. Ein wesentlicher Kritikpunkt bei der Nutzung von NSAIDs ist neben den weitreichenden Nebenwirkungen (MONTEIROSTEAGALL et al. 2013), dass sie dem Abbau der ECM nicht entgegenwirken (COMBLAIN et al. 2016). In dem vorgestellten Modell senkte Ibuprofen jedoch nicht nur PGE, sondern auch die untersuchten Matrixproteinasen. Die Wirkungen fielen jedoch auf Grund der geringen Dosis an Ibuprofen nicht immer signifikant aus. Wie bereits erwähnt, hat PGE2 eine synergistische Wirkung auf iNOS und verschiedene MMPs (LI et al. 2009; ATTUR et al. 2008). Eine Reduktion der PGE2 durch Ibuprofen in diesem Modell hat somit wahrscheinlich ebenfalls eine Reduktion der MMP-3, MMP-13 und iNOS Genexpression zur Folge. Insgesamt lässt sich somit schlussfolgern, dass Ibuprofen zwar nur die PGE Produktion direkt beeinflusst, aber dadurch indirekt auch eine matrixprotektive Wirkung vermitteln kann. Überraschenderweise kommt es in dem vorgestellten Modell durch Ibuprofen zu einem signifikanten Anstieg der iNOS Genexpression in IL-stimulierten Kulturen, welche aber nicht zu einem signifikanten Anstieg von NO führt. In Gliazellen bewirkt Ibuprofen nur einen schwachen Abfall der iNOS 
Genexpression, vermittelt jedoch über postranslationale Mechanismen eine starke Reduktion der Enzymaktivität (STRATMAN et al. 1997). Da in unserem Modell das Endprodukt NO nicht beeinflusst wurde, ist es möglich, dass die iNOS Enzymaktivität ebenfalls über posttranslationale Mechanismen bestimmt wird.

Insgesamt entfaltet im Modell keine der untersuchten Fettsäuren eine so effektive Wirkung wie Ibuprofen. Diese Beobachtung zeigt erneut, dass die Wirkung von Fettsäuren allein wahrscheinlich nicht ausreichend ist, um die Symptome von OA vollständig zu lindern (HANSEN et al. 2008). Dennoch könnte eine Behandlung mit Fischöl eine Senkung der NSAID Dosis ermöglichen und damit vor den schädlichen Nebenwirkungen dieser Medikamentengruppe schützen (FRITSCH et al. 2010b).

Verschiedene Proteinasen sind bei der Degeneration der ECM involviert. Wir untersuchen die Wirkung der n-3 PUFAs auf MMP-3, MMP-13 und ADAMTS-5. MMP-3 gilt als Marker für entzündliche Vorgänge im Gelenk (HEGEMANN et al. 2002), wogegen MMP-13 als Enzym mit der höchsten Umsatzrate für Kollagen II wesentlich zur Matrixdegeneration beiträgt (LI et al. 2017). Entgegen unserer Erwartungen hatte weder EPA noch DHA in unserem Modell einen Einfluss auf die IL-induzierte Expression von MMP-3 und MMP-13. Untersuchungen zur Expression von MMP-3 und MMP-13 in bovinen Chondrozyten konnten eine deutliche Konzentrationsabhängigkeit der Effekte aufdecken. So gewannen beobachtete Effekte erst bei $70 \mu \mathrm{M}$ EPA, also einer dreifach höheren Konzentration, an Signifikanz (ZAINAL et al. 2009). Somit ist zu vermuten, dass die ausbleibenden Effekte in unserem Modell auf die geringe Dosierung der Fettsäuren zurückzuführen sind. Wie bei den eigenen Untersuchungen zur Fettsäureaufnahme deutlich wurde, kommt es nach längerer Inkubation nicht mehr zu einer Steigerung der Akkumulation von EPA in den Zellen. In diesem Falle scheint die lange Inkubationszeit die niedrige Dosis nicht zu kompensieren. Im Gegensatz zu den untersuchten n-3 PUFAs konnte n-6 AA die MMP-3 Expression halbieren und unterschied sich damit in seiner Effizienz nicht von der Positivkontrolle Ibuprofen.

Die Regulation der MMPs findet auf mehreren Ebenen statt. Sie erfolgt neben einer Kontrolle der Genexpression und der gezielten Aktivierung der Pro-MMPs über eine Bindung an ihre natürlichen Hemmstoffe, die TIMPs (CUI et al. 2017). Unsere Studie analysiert daher neben der Genexpression der MMPs auch die Expression von TIMP-2. In einer caninen in vivo Studie konnte in der Synovia von an OA erkrankten Hunden nach der Gabe von Fischöl eine erhöhte TIMP-2 Expression nachgewiesen werden (HANSEN et al. 2008). In einer humanen in vitro Studie hingegen hatten n-3 und n-6 PUFAs keinen Einfluss auf die TIMP-2 mRNA Menge (CURTIS et al. 2002b). Auch in dieser Studie beobachteten wir keine Änderung der TIMP-2 Expression nach einer Supplementierung mit n-3 und n-6 PUFAs. Da auch canine 
Synovialozyten große Mengen an TIMP-2 exprimieren (BEE et al. 2000), ist es wahrscheinlich, dass der in vivo beobachtete Anstieg von TIMP-2 durch eine Expressionsänderung in den Synovialozyten bedingt ist. Es ist daher davon auszugehen, dass die TIMP-2 Genexpression in Chondrozyten durch Fettsäuren nicht zu beeinflussen ist.

ADAMTS-5 und ADAMTS-4 gelten als die wichtigsten Aggrecanasen in OA und spielen beim Abbau der ECM eine Schlüsselrolle. Bei Untersuchungen zum Einfluss von IL-1 $\beta$ auf die ADAMTS-5 Expression kam es zu inkonsistenten Ergebnissen. Dies führte zu der Hypothese, dass die Regulation der ADAMTS-5 Translation und Transkription nach Spezies, Alter und Kulturbedingungen variiert (NAGASE und KASHIWAGI 2003). In Versuchen zu der Wirkung von n-3 PUFAs konnte beobachtet werden, dass nur in Kulturen, deren ADAMTS-5 Expression durch IL induzierbar ist, n-3 PUFAs einen Einfluss auf die ADAMTS-5 Expression haben (ZAINAL et al. 2009). In der eigenen Studie hatten weder IL-1 $\beta$ noch lbuprofen einen Effekt auf ADAMTS-5 und dementsprechend konnte auch unter n-3 PUFAs keine Veränderung der ADAMTS-5 Expression dokumentiert werden. Es ist denkbar, dass die erhöhte ADAMTS-5 Expression in der caninen OA unabhängig von IL-1 $\beta$ entsteht. Sollte dies der Fall sein, ist das vorgestellte Modell nicht geeignet, um die Wirkung von n-3 PUFAs auf die ADAMTS-5 zu untersuchen.

In der vorgelegten Studie wird zum ersten Mal die iNOS Expression und NO Produktion unter dem Einfluss von PUFAs in einem caninen in vitro Modell für OA untersucht. In geringen Mengen hat NO eine protektive Rolle, wogegen es bei höheren Dosen mit reaktiven Sauerstoffspezies zu Peroxinitrit reagiert (ABRAMSON 2008). Peroxinitrit hat eine destruktive Wirkung auf die ECM (CAO et al. 1997; MURRELL et al. 1995; TASKIRAN et al. 1994) und führt zur Apoptose der Chondrozyten (YASUHARA et al. 2005; WHITEMAN et al. 2004). In porzinen Explantkulturen kam es abhängig vom Sauerstoffdruck (20-1\%) nach einer Stimulation mit IL-1 $\beta$ zu einer erhöhten Produktion von Peroxinitrit (CERNANEC et al. 2007). Da im vorgestellten Modell die Zellen unter ca. 17 \% Sauerstoff und unter Einfluss von IL-1 $\beta$ kultiviert wurden, ist eine Bildung von Peroxinitrit wahrscheinlich. Demnach wird eine hohe Menge an NO mit einer erhöhten Menge an Peroxinitrit einhergehen. Unter EPA und unter AA kam es in dieser Studie zu einer geringeren Bildung von NO, hervorgerufen durch eine Reduktion der iNOS Genexpression. Es lässt sich somit die Hypothese aufstellen, dass beide Fettsäuren nicht nur NO senken, sondern auch die Menge an schädlichem Peroxinitrit reduzieren. Eine humane in vitro Studie kommt zu einem ähnlichen Ergebnis. Dort senkten verschiedene Fettsäurekombinationen unter anderem LA und AA sowie LA und EPA gleichermaßen die IL-induzierte NO Produktion der Chondrozyten (SHEN et al. 2004). Neben einer Reduktion der NO Produktion ist zu berücksichtigen, dass es in caninen Fütterungsstudien mit Fischöl zu einem Anstieg von antioxidativen Stoffen im Blut kommt. 
Diese schützen vor ROS und beugen somit zusätzlich einer Bildung von Peroxinitrit vor (BARROUIN-MELO et al. 2016).

PGE2 ist ein Lipidmediator aus AA, welcher in niedrigen Dosen (bis $70 \mathrm{pg} / \mathrm{ml}$ ) eine protektive Wirkung vermittelt (TCHETINA et al. 2007), in hohen Dosen jedoch maßgeblich zur Entzündung und dem Schmerz in osteoarthrotischen Gelenken beiträgt (LEE et al. 2013). Das Schlüsselenzym zur Entstehung von PGE2 ist die COX-2, welche die Reaktion von AA zu PGH2, dem Vorläufer von PGE2, katalysiert (SMITH et al. 2011). Wie zu erwarten, kommt es in AA-supplementierten Kulturen mit und ohne IL-1 $\beta$ zu einem erheblichen Anstieg der PGE Produktion. Als Ausgangsstoff von PGE2 steigert AA die Produktion zum einen durch eine erhöhte Substratverfügbarkeit, zum anderen durch eine allosterische Induktion der COX-2 (SMITH et al. 2011). EPA ist ebenfalls ein Substrat der COX-2 und wird zu dem weniger potenten Eicosanoid PGE3 umgesetzt. EPA hemmt daher über die Konkurrenz mit AA um das reaktive Zentrum der COX-2 die Bildung von PGE2. Außerdem ist bekannt, dass EPA als allosterischer Hemmstoff die Aktivität der COX-2 reduziert (SMITH et al. 2011). Leider gibt es derzeit keinen ELISA, der verlässlich zwischen PGE2 und PGE3 unterscheiden kann. Daher konnten wir in diesem Modell nur die Auswirkung der PUFAs auf die Gesamtmenge an PGE untersuchen und diese bleibt auch nach Zugabe von EPA oder DHA unverändert. Es ist allerdings nicht ausgeschlossen, dass nach der Supplementierung in unserem Modell das weniger potente PGE3 überwiegt. Jedoch ist zu beachten, dass die COX-2 bei einem gemeinsamen Auftreten von AA und EPA den Umsatz von AA gegenüber EPA vorzieht (SMITH et al. 2011). Daher bleibt das Verhältnis von PGE3 zu PGE2 auch nach einer Supplementierung mit EPA im Serum von Hunden gering (1:500) (KEARNS et al. 1999). Auch im vorgestellten Modell fiel der Gehalt an AA in den Zellen nie unter $2 \%$, wahrscheinlich bedingt durch die Zugabe der Fettsäuren über das FCS.

Keine der Fettsäuren hat in unserem Modell einen Einfluss auf die COX-2 Expression. Dies steht im Gegensatz zu anderen Studien, in denen bei ähnlichen oder sogar niedrigeren EPA Dosen eine Reduktion der COX-2 Expression beobachtet wurde (WANN et al. 2010; HURST et al. 2009; ZAINAL et al. 2009; CURTIS et al. 2002b; CURTIS et al. 2000). Auffällig ist dabei, dass sich die COX-2 Expression in Explantkulturen gut durch EPA beeinflussen lässt (WANN et al. 2010; HURST et al. 2009). Ob die Kultivierungsmethode einen Einfluss auf die COX-2 Expression hat, verlangt weitere Untersuchungen. Da es in unserer Studie zu abweichenden Ergebnissen zwischen COX-2 und PGE kam, ist davon auszugehen, dass die PGE Produktion nicht immer über die Genexpression reguliert wird. Daher ergeht die Empfehlung, in zukünftigen Studien neben der COX-2 Expression stets die PGE Produktion zu messen. 
Ein neuer Erklärungsansatz zur Wirkung der n-3 PUFAs liegt in der Lipidersatztherapie. Lipide sind in Form von Glycerophospholipiden und Sphingolipiden Teil der Membran und der Sättigungsgrad ihrer Fettsäuren bestimmt maßgeblich die Fluidität und Dichte einzelner Membrandomänen. Im Falle einer chronisch-degenerativen Krankheit wie OA kommt es zur Oxidation der Fettsäuren in der Membran und dadurch zu veränderten Membraneigenschaften und einem gestörten Zellmetabolismus. Über die Nahrung zugeführte n-3 PUFAs gelten als Bausteine, um die geschädigten Anteile der Zellmembran zu reparieren und schützen so vor Stoffwechselentgleisung und Zelltod (NICOLSON und ASH 2014). Ein weiterer Ansatz ist die Produktion von antiinflammatorischen Lipidmediatoren wie Resolvinen, Protektinen oder Endocannabinoiden (CALDER 2015; WEYLANDT et al. 2012). Auch in unserem Modell sind derartige Überlegungen zur Wirkung der n-3 PUFAs denkbar. 


\section{SCHLUSSFOLGERUNG}

Eine Stimulation der Chondrozyten mit IL-1 $\beta$ führt im vorgestellten Modell zu einem ähnlichen Muster an degenerierenden und entzündlichen Markern wie unter natürlichen Bedingungen in der caninen und humanen OA. Es konnte gezeigt werden, dass $10 \mu \mathrm{M} I \mathrm{~L}-1 \beta$ über $24 \mathrm{~h}$ ausreichend sind, um OA zu imitieren. Im Gegensatz dazu hat eine Stimulation mit TGF- $\beta$ dosisabhängig einen antiinflammatorischen und matrixprotektiven Effekt. Die Zellen in unserem Modell verhalten sich wie Chondrozyten in vivo und zeigen nur wenige Anzeichen für eine fortgeschrittene Entdifferentzierung.

Die supplementierten Fettsäuren werden von den Chondrozyten konzentrationsabhängig aufgenommen und metabolisiert. Trotz der langen Supplementierungsperiode kommt es nicht zu einer Akkumulation der n-3 PUFAs.

EPA hatte auf einzelne inflammatorische Marker einen vorteilhaften Effekt, wogegen eine Supplementierung mit DHA keine signifikanten Effekte hervorrief. Erstaunlicherweise führt eine Supplementierung mit AA ebenfalls zu einer Verbesserung einzelner Marker, andere Entzündungsmarker wie PGE hingegen wurden von AA erheblich induziert.

Insgesamt deckt diese Studie die möglichen Mechanismen hinter der oftmals vermuteten positiven Wirkung von Fischöl bei der caninen OA auf. Sie bestärkt außerdem die Hypothese, dass beim Hund vor allem n-3 PUFA EPA, aber auch n-6 PUFAs wie AA eine positive Auswirkung auf den Krankheitsverlauf haben könnten. Es konnte gezeigt werden, dass auch eine niedrige Dosis der PUFAs über einen längeren Zeitraum eine positive Auswirkung auf osteoarthrotische Marker hat. Damit wird erneut deutlich, wie nützlich eine ausreichende und ausgewogene Einnahme von PUFAs zur unterstützenden Therapie degenerativer Gelenkserkrankungen ist. Herauszustellen ist dabei, dass von allen untersuchten Fettsäuren EPA die größte Effektivität aufzuweisen scheint und somit der Einnahme von EPA die größte Bedeutung zuzusprechen ist. 


\section{ZUSAMMENFASSUNG}

\section{Nadja Adler}

Die Wirkung mehrfach ungesättigter Fettsäuren auf Schlüsselproteine der Knorpeldegeneration in einem Modellsystem für die canine Osteoarthrose

Veterinär-Physiologisch-Chemisches Institut, Veterinärmedizinische Fakultät, Universität Leipzig

Eingereicht im März 2020

69 Seiten, 2 Publikationen, 6 Abbildungen, 233 Literaturangaben

Schlüsselwörter: Canine Osteoarthrose, PUFA, Chondrozyten, Interleukin-1 $\beta$, Transforming Growth Faktor- $\beta$, Zellkultur

Einleitung: Osteoarthrose $(\mathrm{OA})$ ist eine der häufigsten muskuloskelettalen Erkrankungen beim Hund und wird definiert durch einen fortschreitenden Verlust der Knorpelschicht auf den Gelenksflächen. Therapeutika erster Wahl, wie nichtsteroidale Antiphlogistika, wirken rein palliativ und haben insbesondere bei der Langzeitgabe schädliche Nebenwirkungen. Bei der Suche nach Alternativen rückten Ergänzungsfuttermittel in den Focus der Forschung. Dabei zeigten mehreren Studien, dass eine Fütterung von Fischöl die klinischen Symptome von OA bei Hunden verbessert. Der dahinterliegende Wirkmechanismus ist jedoch beim Hund nicht erforscht.

Ziele der Untersuchungen: Ziel dieser Studie war demnach, den genauen Wirkmechanismus von mehrfach ungesättigten Fettsäuren (PUFA) auf ausgewählte Schlüsselfaktoren der Knorpeldegeneration in einem Modellsystem der caninen OA zu untersuchen.

Material und Methoden: Wir etablierten ein Protokoll zur Isolierung von caninen Chondrozyten, kultivierten die Zellen erfolgreich bis zur Konfluenz und kryokonservierten sie für die weiteren Versuche. Um die Ansprechbarkeit der Zellen auf verschiedene Zytokine zu untersuchen, wurden die Zellen über $24 \mathrm{~h}$ mit $10 \mathrm{ng} / \mathrm{ml}$ Interleukin-1 $\beta$ (IL-1 $\beta$ ) und mit 1 bis $10 \mathrm{ng} / \mathrm{ml}$ Transforming Growth Faktor- $\beta$ (TGF- $\beta$ ) stimuliert und die Genexpression von Matrixproteinasen, induzierbarer Stickstoffmonoxid Synthase (iNOS) und Cyclooxygenase-2 (COX-2) sowie die Produktion von Stickstoffmonoxid (NO) und Prostaglandin E (PGE) gemessen (4 Spender, $\mathrm{N}=3$ ). Auf Basis des etablierten Models wurden in einer zweiten Versuchsreihe die Zellen über 6 Tage mit n-3 Eicosapentaensäure (EPA), n-3 Docosahexaensäure (DHA) oder n-6 Arachidonsäure (AA) kultiviert und anschließend über $48 \mathrm{~h}$ mit IL-1 $\beta$ stimuliert. Die Veränderung der IL-induzierte Genexpression von 
Matrixproteinasen, iNOS und COX-2 sowie die Produktion von PGE und NO unter Einfluss der Fettsäuren wurde analysiert (6 Spender, N=4). Darüber hinaus wurde die Fettsäureaufnahme und der Fettsäuremetabolismus via Gaschromatographie überprüft.

Um die Wirkungen der Fettsäuren und Stimulantien zu verifizieren, wurden die Daten einer zweifachen Varianzanalyse (AV) unterzogen. Bei signifikanten Einflüssen der Faktoren folgte ein Post-hoc-Test (Dunnett's Test für die PUFA bzw. ein Bonferroni Test für die Stimulanzien). Die Signifikanzniveaus für AV- und die Post-hoc Tests wurden auf $\alpha=0,01$ eingestellt.

Ergebnisse: Unter der Stimulation mit IL-1 $\beta$ kam es zu einem signifikanten Anstieg von degenerativen und entzündlichen Markern. Das Muster der Marker entsprach dabei dem Muster, welches unter natürlichen Bedingungen in erkrankten Gelenken vorzufinden ist. Somit haben wir ein simples und dennoch repräsentatives Modell für die canine OA etabliert. Im Gegensatz zu IL-1 $\beta$ reduzierte TGF- $\beta$ konzentrationsabhängig signifikant den von IL-1 $\beta$ induzierten Anstieg der inflammatorischen Marker und stellt sich somit als Gegenspieler zu diesem proinflammatorischen Zytokin dar. Die gegensätzliche Antwort der Zellen auf beide Zytokine bewies, dass die Chondrozyten in unserem Modell Charakteristika von differenzierten Zellen aufweisen.

Alle Fettsäuren wurden konzentrationsabhängig in die Zellen aufgenommen und metabolisiert. EPA reduzierte die IL-induzierte Expression von iNOS und die damit im Zusammenhang stehende Produktion von NO signifikant. AA reduzierte ebenfalls iNOS und NO und außerdem die Expression von Matrixmetalloproteinase-3 signifikant. Auf der anderen Seite steigerte AA signifikant die Produktion von PGE und die Expression von Aggrecanase ADAMTS-5. DHA hatte auf keinen der untersuchten Marker einen Effekt.

Schlussfolgerungen: Zusammenfassend bestätigen die Ergebnisse dieser Studie die in Fütterungsversuchen dokumentierte positive Wirkung von n-3 PUFAs bei der caninen OA und bieten zudem eine Erklärung für die dahinterliegenden Mechanismen. Hervorzuheben ist, dass in dieser Studie nicht nur EPA, sondern auch AA eine positive Wirkung auf einzelne Marker erzielen. EPA scheint von allen untersuchten Fettsäuren die höchste Effektivität zu haben. Eine geringe Dosis an Fettsäuren über einen längeren Zeitraum führte nicht zu einer Akkumulation der Fettsäuren und hatte daher auf einige untersuchte Marker nur eine geringe Wirkung. Insgesamt lässt sich schlussfolgern, dass eine ausreichende Menge und ausgewogenes Verhältnis von n-3 und n-6 PUFA als unterstützende Therapie bei chronischen Gelenkserkrankungen beim Hund von großer Wichtigkeit ist. Besonders ein hoher Gehalt an EPA scheint dabei eine hohe Bedeutung für die Effektivität zu haben. 


\section{SUMMARY}

\section{Nadja Adler}

The effect of polyunsaturated fatty acids on key proteins of cartilage degeneration in a model system of canine osteoarthritis

Institute of Biochemistry, Faculty of Veterinary Medicine, University of Leipzig

Submitted in March 2020

69 pages, 2 publications, 6 figures, 233 references

Keywords: Canine osteoarthritis, PUFA, chondrocytes, cell culture, interleukin-1 $\beta$, transforming growth factor- $\beta$

Introduction: Osteoarthrosis (OA) is one of the most common musculoskeletal diseases in dogs and is defined by the progressive loss of the protective joint cartilage layer. First-choice treatments, like nonsteroidal anti-inflammatory drugs, act palliative only and are known to have harmful side effects especially in long-term usage. The urge to find alternative treatments moved nutraceuticals into the focus of research. In multiple trials, feeding fish oil improved the clinical symptoms of osteoarthritis in dogs. However, the underlying molecular mechanisms have not been investigated in dogs.

Aim of the Study: The aim of this study was therefore to further clarify how polyunsaturated fatty acids affect key factors of cartilage degeneration in a cell culture model for canine OA.

Materials and methods: We established a protocol for the isolation of canine chondrocytes, cultivated them successfully until confluency and cryoconservated them for further experiments. To examine the response of the cells to different cytokines, cells were stimulated for $24 \mathrm{~h}$ with $10 \mathrm{ng} / \mathrm{ml}$ Interleukin-1 $\beta$ (IL-1 $\beta$ ) or 1 to $10 \mathrm{ng} / \mathrm{ml}$ Transforming Growth Factor- $\beta$ (TGF- $\beta$ ). The gene expression of matrix proteinases, inducible nitric oxide synthase (iNOS) and cyclooxygenase-2 (COX-2), the production of nitric oxide (NO) and prostaglandin E (PGE) were measured (4 donors, $\mathrm{N}=3$ ). Using the established model, cells in the second trial were incubated with eicosapentaenoic acid (EPA), docosahexaenoic acid (DHA) and arachidonic acid (AA) for 6 days and subsequently stimulated with IL-1 $\beta$ for another $48 \mathrm{~h}$. The change in IL-induced gene expression of matrix proteinases, iNOS and COX-2 as well as the production of NO and PGE under the influence of n-3 EPA, n-3 DHA and n-6 AA was analysed (6 donors, $\mathrm{N}=4$ ). 
To verify the effects of the fatty acids and the stimulants, data were analysed with a two-factorial analysis of variance (ANOVA). When there was a significant effect of the factors, a post-hoc test was performed (Dunnett's test for PUFA, Bonferroni test for stimulants). Significance level for ANOVA- and the post hoc test was set at $\alpha=0,01$.

Results: Stimulation with IL-1 $\beta$ led to a significant increase of degenerative and inflammatory markers. This pattern of responsiveness was comparable to the events in naturally occurring OA. We therefore have established a simple yet representative model for canine OA. In contrast to IL-1 $\beta$, TGF- $\beta$ significantly decreased the IL-induced inflammatory markers in a dose-dependent manner and therefore could counteract IL-1 $\beta$. The response of the cells to the cytokines indicates, that in our model, the chondrocytes have characteristics of differentiated cells.

All fatty acids were incorporated in a dose-dependent manner and metabolized. EPA decreased the IL-induced gene expression of iNOS and reduced the concomitant production of NO significantly. AA also decreased iNOS and NO significantly and downregulated the gene expression of matrix metalloproteinase-3 significantly. On the other hand, AA significantly increased the production of PGE and the gene expression of the aggrecanase ADAMTS-5. DHA had no effect on any of the markers.

Conclusions: Taking together, the results of this study add further weight to the beneficial effect of n-3 PUFAs in canine OA and furthermore provide an explanation for the underlying mechanism. It is of importance, that not only the n-3 fatty acid EPA but also the n- 6 fatty acid AA could provide beneficial effects on several markers. EPA seems to be the most effective of all fatty acids included in this study. A low concentration of fatty acids over a long period of time did not lead to an accumulation of fatty acids and therefore had a rather small impact on some of the investigated markers. Therefore, an optimal ratio between n- 3 and $n-6$ and the adequate amount of fatty acids seems to be of high importance when treating chronic degenerative joint disease in dogs. However, a high content of EPA seems to be particularly effective. 


\section{LITERATURVERZEICHNIS}

Abramson SB. Osteoarthritis and nitric oxide. Osteoarthritis Cartilage. 2008;16 Suppl2:S15-S20

Adkisson HD, Trancik TM, Zarrinkar PP, Wuthier RE. Accumulation of essential fatty acids in hyaline cartilage with aging and osteoarthritis: Possible implications in development of osteoarthritis. Orthop Trans. 1990:423-4.

Adkisson HD, Risener FS, Zarrinkar PP, Walla MD, Christie WW, Wuthier RE. Unique fatty acid composition of normal cartilage: Discovery of high levels of $n-9$ eicosatrienoic acid and low levels of $n-6$ polyunsaturated fatty acids. FASEB J. 1991;5(3):344-53.

Aigner T, Fundel K, Saas J, Gebhard PM, Haag J, Weiss T et al. Large-scale gene expression profiling reveals major pathogenetic pathways of cartilage degeneration in osteoarthritis. Arthritis Rheum. 2006;54(11):3533-44.

Allen MJ. Advances in total joint replacement in small animals. J Small Anim Pract. 2012;53(9):495-506.

Alibegović A. Cartilage: A new parameter for the determination of the postmortem interval? J Forensic Leg Med. 2014;27:39-45. Doi: 10.1016/j.jflm.2014.08.005.

Ameye LG, Young MF. Animal models of osteoarthritis: Lessons learned while seeking the 'Holy Grail'. Curr Opin Rheumatol. 2006;18(5):537-47.

Anderson AS, Loeser RF. Why is osteoarthritis an age-related disease? Best Pract Res Clin Rheumatol. 2010;24(1):15-26.

Anderson KL, O’Neill DG, Brodbelt DC, Church DB, Meeson RL, Sargan D et al. Prevalence, duration and risk factors for appendicular osteoarthritis in a UK dog population under primary veterinary care. Sci Rep. 2018;8(1):5641. Doi: 10.1038/s41598-018-23940-z.

Aref-Eshghi E, Liu M, Harper PE, Doré J, Martin G, Furey A et al. Overexpression of MMP13 in human osteoarthritic cartilage is associated with the SMAD-independent TGF- $\beta$ signalling pathway. Arthritis Res Ther. 2015;17(1):264. Doi:10.1186/s13075-015-0788-x.

Arkill KP, Winlove CP. Fatty acid transport in articular cartilage. Arch Biochem Biophys. 2006;456(1):71-8.

Arterburn LM, Hall EB, Oken H. Distribution, interconversion, and dose response of $n-3$ fatty acids in humans. Am J Clin Nutr. 2006;83(6 Suppl):1467S-1476S. 
Attur M, Al-Mussawir HE, Patel J, Kitay A, Dave M, Palmer G et al. Prostaglandin E2 exerts catabolic effects in osteoarthritis cartilage: Evidence for signaling via the EP4 receptor. J Immunol. 2008;181(7):5082-8.

Attur M, Belitskaya-Levy I, Oh C, Krasnokutsky S, Greenberg J, Samuels J et al. Increased interleukin-1beta gene expression in peripheral blood leukocytes is associated with increased pain and predicts risk for progression of symptomatic knee osteoarthritis. Arthritis Rheum. 2011;63(7):1908-17.

Attur M, Dave M, Abramson SB, Amin A. Activation of diverse eicosanoid pathways in osteoarthritic cartilage: A lipidomic and genomic analysis. Bull NYU Hosp Jt Dis. 2012;70(2):99-108.

Barrouin-Melo SM, Anturaniemi J, Sankari S, Griinari M, Atroshi F, Ounjaijean S et al. Evaluating oxidative stress, serological- and haematological status of dogs suffering from osteoarthritis, after supplementing their diet with fish or corn oil. Lipids Health Dis. 2016;15(1):139. Doi: 10.1186/s12944-016-0304-6.

Bauer JE. Responses of dogs to dietary omega-3 fatty acids. J Am Vet Med Assoc. 2007;231(11):1657-61.

Bauer JE. Essential fatty acid metabolism in dogs and cats. Rev Bras Zootecn. 2008;37(special issue):20-7.

Baugé C, Legendre F, Leclercq S, Elissalde JM, Pujol JP, Galéra P et al. Interleukin-1beta impairment of transforming growth factor beta1 signaling by down-regulation of transforming growth factor beta receptor type II and up-regulation of Smad7 in human articular chondrocytes. Arthritis Rheum. 2007;56(9):3020-32.

Baugé C, Girard N, Lhuissier E, Bazille C, Boumediene K. Regulation and role of TGFbeta signaling pathway in aging and osteoarthritis joints. Aging Dis. 2014;5(6):394-405.

Beale BS. Use of nutraceuticals and chondroprotectants in osteoarthritic dogs and cats. Vet Clin North Am Small Anim Pract. 2004;34(1):271-89.

Bee A, Barnes A, Jones MD, Robertson DH, Clegg PD, Carter SD. Canine TIMP-2: Purification, characterization and molecular detection. Vet J. 2000;160(2):126-34.

Benya PD, Padilla SR, Nimni ME. Independent regulation of collagen types by chondrocytes during the loss of differentiated function in culture. Cell. 1978;15(4):1313-21.

Berenbaum F. Osteoarthritis as an inflammatory disease (osteoarthritis is not osteoarthrosis!). Osteoarthritis Cartilage. 2013;21(1):16-21. 
Blanco FJ, Geng Y, Lotz M. Differentiation-dependent effects of IL-1 and TGF-beta on human articular chondrocyte proliferation are related to inducible nitric oxide synthase expression. $J$ Immunol. 1995;154(8):4018-26.

Blanco FJ, Lotz M. IL-1-induced nitric oxide inhibits chondrocyte proliferation via PGE2. Exp Cell Res. 1995;218(1):319-25.

Bland S. Canine osteoarthritis and treatments: A review. Vet Sci Dev. 2015;5(2):84-89. Doi: $10.4081 /$ vsd.2015.5931.

Blaney Davidson EN, Scharstuhl A, Vitters EL, van der Kraan PM, van den Berg WB. Reduced transforming growth factor-beta signaling in cartilage of old mice: Role in impaired repair capacity. Arthritis Res Ther 2005;7(6):R1338-47. Doi: 10.1186/ar1833.

Blaney Davidson EN, van Caam APM, Vitters EL, Bennink MB, Thijssen E, van den Berg WB et al. TGF-beta is a potent inducer of Nerve Growth Factor in articular cartilage via the ALK5-Smad2/3 pathway. Potential role in OA related pain? Osteoarthritis Cartilage. 2015;23(3):478-86.

Boe C, Vangsness CT. Fish oil and osteoarthritis: Current evidence. Am J Orthop (Belle Mead NJ). 2015;44(7):302-5.

Böttcher P, Ludewig E, Grevel V. Konservative Frakturversorgung. Teil 3: Komplikationen. Kleintier konkret- J Small Anim Practitioner. 2007a;10(03):10-16.

Böttcher P., Zeißler M., Winkels P., Ludewig E., Maierl J., Grevel V. Mosaikplastik am Ellbogengelenk eines Hundes. Technik des osteochondralen Transfers und Einschätzung der resultierenden Gelenkkongruenz mittels Computertomographie und computertomographischer Osteoabsorptiometrie. Tierärztl Prax. 2007b;35(K):253-260.

Bound NJ, Upjohn MJ, Jackson S, Baines SJ. Assessment of veterinary practitioners in the British Isles' approaches towards the management of canine osteoarthritis. Veterinary Rec. 2011;168(21):563. Doi: 10.1136/vr.d1021.

Brenna JT, Salem N, JR, Sinclair AJ, Cunnane SC. Alpha-linolenic acid supplementation and conversion to n-3 long-chain polyunsaturated fatty acids in humans. Prostaglandins Leukot Essent Fatty Acids. 2009;80(2-3):85-91.

Brown SA, Brown CA, Crowell WA, Barsanti JA, Kang CW, Allen T et al. Effects of dietary polyunsaturated fatty acid supplementation in early renal insufficiency in dogs. J Lab Clin Med. 2000;135(3):275-86.

Buckwalter JA, Mankin HJ, Grodzinsky AJ. Articular cartilage and osteoarthritis. Instr Course Lect. 2005;54:465-80. 
Burton-Wurster N, Liu W, Matthews GL, Lust G, Roughley PJ, Glant TT et al. TGF beta 1 and biglycan, decorin, and fibromodulin metabolism in canine cartilage. Osteoarthritis Cartilage. 2003;11(3):167-76.

Calder PC. Marine omega-3 fatty acids and inflammatory processes: Effects, mechanisms and clinical relevance. Biochim Biophys Acta. 2015;1851(4):469-84. Doi: 10.1016/j.bbalip.2014.08.010.

Cao M, Westerhausen-Larson A, Niyibizi C, Kavalkovich K, Georgescu HI, Rizzo CF et al. Nitric oxide inhibits the synthesis of type-Il collagen without altering Col2A1 mRNA abundance: Prolyl hydroxylase as a possible target. Biochem J. 1997;324(Pt 1):305-10.

Caron MMJ, Emans PJ, Coolsen MME, Voss L, Surtel DAM, Cremers A et al. Redifferentiation of dedifferentiated human articular chondrocytes: Comparison of $2 \mathrm{D}$ and $3 \mathrm{D}$ cultures. Osteoarthritis Cartilage. 2012;20(10):1170-8.

Carrig CB. Diagnostic imaging of osteoarthritis. Vet Clin North Am Small Anim Pract. 1997:777-814

Cawston T. Matrix metalloproteinases and TIMPs: Properties and implications for the rheumatic diseases. Mol Med Today. 1998;4(3):130-7.

Cernanec JM, Weinberg JB, Batinic-Haberle I, Guilak F, Fermor B. Influence of oxygen tension on interleukin 1-induced peroxynitrite formation and matrix turnover in articular cartilage. J Rheumatol. 2007;34(2):401-7.

Chen J, Huang J, Du W, Tong P. Expression and significance of MMP3 in synovium of knee joint at different stage in osteoarthritis patients. Asian Pac J Trop Med. 2014;7(4):297-300.

Chen R, Mian M, Fu M, Zhao JY, Yang L, Li Y et al. Attenuation of the progression of articular cartilage degeneration by inhibition of TGF-beta1 signaling in a mouse model of osteoarthritis. Am J Pathol. 2015;185(11):2875-85. Doi: 10.1016/j.ajpath.2015.07.003.

Cicuttini FM, Wluka AE. Osteoarthritis: Is OA a mechanical or systemic disease? Nat Rev Rheumatol. 2014;10(9):515-6. Doi: 10.1038/nrrheum.2014.114.

Cigan AD, Nims RJ, Albro MB, Esau JD, Dreyer MP, Vunjak-Novakovic G et al. Insulin, ascorbate, and glucose have a much greater influence than transferrin and selenous acid on the in vitro growth of engineered cartilage in chondrogenic media. Tissue Eng Part $A$. 2013;(00):1-8.

Clark CA, Li T-F, Kim K-O, Drissi H, Zuscik MJ, Zhang X et al. Prostaglandin E2 inhibits BMP signaling and delays chondrocyte maturation. J Orthop Res. 2009;27(6):785-92. 
Cleland KA, James MJ, Neumann MA, Gibson RA, Cleland LG. Differences in fatty acid composition of immature and mature articular cartilage in humans and sheep. Lipids. 1995;30(10):949-53.

Clements DN, Carter SD, Innes JF, Ollier WER, Day PJR. Analysis of normal and osteoarthritic canine cartilage mRNA expression by quantitative polymerase chain reaction. Arthritis Res Ther. 2006;8(6):R158. Doi: 10.1186/ar2053.

Clements DN, Fitzpatrick N, Carter SD, Day PJR. Cartilage gene expression correlates with radiographic severity of canine elbow osteoarthritis. Vet J. 2009;179(2):211-8.

CliniPharm/CliniTox [Internet]. Zürich: Institut für Veterinärpharmakologie und -toxikologie Antiphlogistika (schwache Analgetika); 2020a [zitiert vom 12.01.2020]. Verfügbar unter: <http://www.vetpharm.uzh.ch/reloader.htm?wir/WIK/WIP_E0.htm?inhalt_c.htm>.

CliniPharm/CliniTox [Internet]. Zürich: Institut für Veterinärpharmakologie und -toxikologie Cortison. 2020b [zitiert vom 12.01.2020]. Verfügbar unter: <https://www.vetpharm.uzh.ch/wir/00000005/3065_01.htm>

Comblain F, Serisier S, Barthelemy N, Balligand M, Henrotin Y. Review of dietary supplements for the management of osteoarthritis in dogs in studies from 2004 to 2014. J Vet Pharmacol Ther. 2016;39(1):1-15. Doi: 10.1111/jvp.12251.

Conquer JA, Holub BJ. Dietary docosahexaenoic acid as a source of eicosapentaenoic acid in vegetarians and omnivores. Lipids. 1997;32(3):341-5.

Cook JL, Payne J. Surgical treatment of osteoarthritis. Vet Clin North Am Small Anim Pract. 1997:931-44.

Cook JL, Anderson CC, Kreeger JM, Tomlinson JL. Effects of human recombinant interleukin-1 beta on canine articular chondrocytes in three-dimensional culture. Am J Vet Res. 2000;61(7):766-70.

Csaki C, Matis U, Mobasheri A, Ye H, Shakibaei M. Chondrogenesis, osteogenesis and adipogenesis of canine mesenchymal stem cells: A biochemical, morphological and ultrastructural study. Histochem Cell Biol. 2007;128(6):507-20.

Cui N, Hu M, Khalil RA. Biochemical and biological attributes of matrix metalloproteinases. Prog Mol Biol Transl Sci. 2017;147:1-73. Doi: 10.1016/bs.pmbts.2017.02.005.

Curtis CL, Hughes CE, Flannery CR, Little CB, Harwood JL, Caterson B. N-3 fatty acids specifically modulate catabolic factors involved in articular cartilage degradation. J Biol Chem. 2000;275(2):721-4. 
Curtis CL, Rees SG, Cramp J, Flannery CR, Hughes CE, Little CB et al. Effects of n-3 fatty acids on cartilage metabolism. Proc Nutr Soc. 2002a;61(03):381-9.

Curtis CL, Rees SG, Little CB, Flannery CR, Hughes CE, Wilson C et al. Pathologic indicators of degradation and inflammation in human osteoarthritic cartilage are abrogated by exposure to n-3 fatty acids. Arthritis Rheum. 2002b;46(6):1544-53.

Curtis CL, Harwood JL, Dent CM, Caterson B. Biological basis for the benefit of nutraceutical supplementation in arthritis. Drug Discov Today. 2004;9(4):165-72.

Daheshia M, Yao JQ. The Interleukin 1 beta Pathway in the pathogenesis of osteoarthritis. J Rheumatol. 2008;35(12):2306-12.

Damyanovich AZ, Staples JR, Chan AD, Marshall KW. Comparative study of normal and osteoarthritic canine synovial fluid using $500 \mathrm{MHz} 1 \mathrm{H}$ magnetic resonance spectroscopy. J Orthop Res. 1999;17(2):223-31.

Demoor-Fossard M, Boittin M, Redini F, Pujol JP. Differential effects of interleukin-1 and transforming growth factor beta on the synthesis of small proteoglycans by rabbit articular chondrocytes cultured in alginate beads as compared to monolayers. Mol Cell Biochem. 1999;199(1-2):69-80.

Dycus DL, Au AY, Grzanna MW, Wardlaw JL, Frondoza CG. Modulation of inflammation and oxidative stress in canine chondrocytes. Am J Vet Res. 2013;74(7):983-9.

Elford PR, Graeber M, Ohtsu H, Aeberhard M, Legendre B, Wishart WL et al. Induction of swelling, synovial hyperplasia and cartilage proteoglycan loss upon intra-articular injection of transforming growth factor beta-2 in the rabbit. Cytokine. 1992;4(3):232-8.

Fawthrop FW, Frazer A, Russell RGG, Bunning RAD. Effects of transforming growth factor beta on the production of prostaglandin $E$ and caseinase activity of unstimulated and interleukin 1-stimulated human articular chondrocytes in culture. $\mathrm{Br} J$ Rheumatol. $1997 ; 36(7): 729-34$.

Felson DT. Osteoarthritis as a disease of mechanics. Osteoarthritis Cartilage. 2013;21(1):10-5.

Fernandes JC, Martel-Pelletier J, Pelletier J-P. The role of cytokines in osteoarthritis pathophysiology. Biorheology. 2002;39(1-2):237-46.

Fitzgerald JB, Jin M, Dean D, Wood DJ, Zheng MH, Grodzinsky AJ. Mechanical compression of cartilage explants induces multiple time-dependent gene expression patterns and involves intracellular calcium and cyclic AMP. J Biol Chem. 2004;279(19):19502-11. 
Fitzpatrick N, Yeadon R, Smith TJ. Early clinical experience with osteochondral autograft transfer for treatment of osteochondritis dissecans of the medial humeral condyle in dogs. Vet Surg. 2009;38(2):246-60.

Fritsch D, Allen TA, Dodd CE, Jewell DE, Sixby KA, Leventhal PS et al. Dose-titration effects of fish oil in osteoarthritic dogs. J Vet Intern Med. 2010a;24(5):1020-6.

Fritsch DA, Timothy AA, Dodd CE, Jewell DE, Sixby KA, Leventhal PS et al. A multicenter study of the effect of dietary supplementation with fish oil omega-3 fatty acids on carprofen dosage in dogs with osteoarthritis. J Am Vet Med Assoc. 2010b;236(5):535-9.

Frye CW, Shmalberg JW, Wakshlag JJ. Obesity, exercise and orthopedic disease. Vet Clin North Am Small Anim Pract. 2016;46(5):831-41.

Fuchs J, Rabenberg M, Scheidt-Nave C. Prävalenz ausgewählter muskuloskelettaler Erkrankungen. Bundesgesundheitsbl. 2013;56:668-77. Doi: 10.1007/s00103-013-1687-4.

Fujita Y, Hara Y, Nezu Y, Yamaguchi S, Schulz KS, Tagawa M. Direct and indirect markers of cartilage metabolism in synovial fluid obtained from dogs with hip dysplasia and correlation with clinical and radiographic variables. Am J Vet Res. 2005;66(12):2028-33.

Glasson SS, Askew R, Sheppard B, Carito B, Blanchet T, Ma H et al. Deletion of active ADAMTS5 prevents cartilage degradation in a murine model of osteoarthritis. Nature. 2005;434(7033):644-8.

Gonzalez MJ, Schemmel RA, Dugan L, JR, Gray JI, Welsch CW. Dietary fish oil inhibits human breast carcinoma growth: A function of increased lipid peroxidation. Lipids. 1993;28(9):827-32.

Gosset M, Berenbaum F, Salvat C, Sautet A, Pigenet A, Tahiri K et al. Crucial role of visfatin/pre-B cell colony-enhancing factor in matrix degradation and prostaglandin E2 synthesis in chondrocytes: Possible influence on osteoarthritis. Arthritis Rheum. 2008;58(5):1399-409.

Guerne PA, Carson DA, Lotz M. IL-6 production by human articular chondrocytes: Modulation of its synthesis by cytokines, growth factors, and hormones in vitro. J Immunol. 1990;144(2):499-505.

Gupta T, Zielinska B, McHenry J, Kadmiel M, Haut Donahue TL. IL-1 and iNOS gene expression and $\mathrm{NO}$ synthesis in the superior region of meniscal explants are dependent on the magnitude of compressive strains. Osteoarthritis Cartilage. 2008;16(10):1213-9.

Hall JA, Jewell DE. Feeding healthy beagles medium-chain triglycerides, fish oil, and carnitine offsets age-related changes in serum fatty acids and carnitine metabolites. PLoS One. 2012;7(11):e49510. Doi: 101371/journal.pone.0049510. 
Hansen RA, Harris MA, Pluhar GE, Motta T, Brevard S, Ogilvie GK et al. Fish oil decreases matrix metalloproteinases in knee synovia of dogs with inflammatory joint disease. J Nutr Biochem. 2008;19(2):101-8.

Harris WS, DiRienzo MA, Sands SA, George C, Jones PG, Eapen AK. Stearidonic acid increases the red blood cell and heart eicosapentaenoic acid content in dogs. Lipids. 2007;42(4):325-33.

Harvey AK, Hrubey PS, Chandrasekhar S. Transforming growth factor-beta inhibition of interleukin-1 activity involves down-regulation of interleukin-1 receptors on chondrocytes. Exp Cell Res. 1991;195(2):376-85.

Haseeb A, Haqqi TM. Immunopathogenesis of osteoarthritis. Clin Immunol. 2013;146(3):185-96. Doi: 10.1016/j.clim.2012.12.011.

Hegemann N, Kohn B, Brunnberg L, Schmidt MF. Biomarkers of joint tissue metabolism in canine osteoarthritic and arthritic joint disorders. Osteoarthritis Cartilage. 2002;10(9):714-21.

Henrotin YE, Bruckner P, Pujol J-PL. The role of reactive oxygen species in homeostasis and degradation of cartilage. Osteoarthritis Cartilage. 2003;11(10):747-55.

Henrotin Y, Sanchez C, Balligand M. Pharmaceutical and nutraceutical management of canine osteoarthritis: Present and future perspectives. Vet J. 2005;170(1):113-23.

Hielm-Björkman A, Roine J, Elo K, Jouni J, Outi L-V. An un-commissioned randomized, placebo-controlled double-blind study to test the effect of deep sea fish oil as a pain reliever for dogs suffering from canine OA. BMC Vet Res. 2012;(8):157-70.

Hodge WA, Fijan RS, Carlson KL, Burgess RG, Harris WH, Mann RW. Contact pressures in the human hip joint measured in vivo. Proc Natl Acad Sci U S A. 1986;83(9):2879-83.

Houard X, Goldring MB, Berenbaum F. Homeostatic mechanisms in articular cartilage and role of inflammation in osteoarthritis. Curr Rheumatol Rep. 2013;15(11):375. Doi: 10.1007/s11926013-0375-6.

Hunziker EB. Articular cartilage repair: Basic science and clinical progress. A review of the current status and prospects. Osteoarthritis Cartilage. 2002;10(6):432-63.

Hurst S, Rees SG, Randerson PF, Caterson B, Harwood JL. Contrasting effects of n-3 and n-6 fatty acids on cyclooxygenase-2 in model systems for arthritis. Lipids. 2009;44(10):889-96.

Johnson Cl, Argyle DJ, Clements DN. In vitro models for the study of osteoarthritis. Vet J. 2016;209:40-9. 
Johnston SA. Osteoarthritis. Joint anatomy, physiology, and pathobiology. Vet Clin North Am Small Anim Pract. 1997;27(4):699-723.

Kang S, Yoo SP, Kim B. Effect of chondrocyte passage number on histological aspects of tissue-engineered cartilage. Biomed Mater Eng. 2007;17(5):269-76.

Kaps C, Fuchs S, Endres M, Vetterlein S, Krenn V, Perka C et al. Molekulare Charakterisierung von gezüchteten humanen dreidimensionalen Chondrozytentransplantaten. Orthopäde. 2004;33(1):76-85.

Kearns RJ, Hayek MG, Turek JJ, Meydani M, Burr JR, Greene RJ et al. Effect of age, breed and dietary omega-6 (n-6): omega-3 (n-3) fatty acid ratio on immune function, eicosanoid production, and lipid peroxidation in young and aged dogs. Vet Immunol Immunop. 1999;69(2-4):165-83.

Kenneth W, Lima EG, Liming B, O'Connor CJ, Jayabalan P, Stoker AM et al. Passaged adult chondrocytes can form engineered cartilage with functional mechanical properties: A canine model. Tissue Eng Part A. 2010;16(3):1041-51.

Kevorkian L, Young DA, Darrah C, Donell ST, Shepstone L, Porter S et al. Expression profiling of metalloproteinases and their inhibitors in cartilage. Arthritis Rheum. 2004;50(1):131-41.

Kim T-W, Giorgi M. A brief overview of the coxib drugs in the veterinary field. Am J Anim Vet Sci. 2013;8:89-97. Doi: 10.3844/ajavssp.2013.89.97.

Kinzel S, Hein S, Scheven C von, Kupper W. 10 years experience with denervation of the hip joint capsule for treatment of canine hip joint dysplasia and arthrosis. Berl Munch Tierarztl Wochenschr. 2002;115(1-2):53-6.

Kirby Shaw K, Rausch-Derra LC, Rhodes L. Grapiprant: An EP4 prostaglandin receptor antagonist and novel therapy for pain and inflammation. Vet Med Sci. 2015,2(1):3-9. Doi: $10.1002 / v m s 3.13$.

Kokebie R, Aggarwal R, Lidder S, Hakimiyan AA, Rueger DC, Block JA et al. The role of synovial fluid markers of catabolism and anabolism in osteoarthritis, rheumatoid arthritis and asymptomatic organ donors. Arthritis Res Ther. 2011;13(2):R50. Doi: 10.1186/ar3293.

Korotkova M, Jakobsson P. Persisting eicosanoid pathways in rheumatic diseases. Nat Rev Rheumatol. 2014;10(4):229-41.

Kosinska MK, Mastbergen SC, Liebisch G, Wilhelm J, Dettmeyer RB, Ishaque B et al. Comparative lipidomic analysis of synovial fluid in human and canine osteoarthritis. Osteoarthritis Cartilage. 2016;24(8):1470-8. 
Kuroki K, Stoker AM, Cook JL. Effects of proinflammatory cytokines on canine articular chondrocytes in a three-dimensional culture. Am J Vet Res. 2005;66(7):1187-96.

Kuroki K, Stoker AM, Sims HJ, Cook JL. Expression of Toll-like receptors 2 and 4 in stifle joint synovial tissues of dogs with or without osteoarthritis. Am J Vet Res. 2010;71(7):750-4.

Kyrkanides S, Tallents RH, Miller JH, Olschowka ME, Johnson R, Yang M et al. Osteoarthritis accelerates and exacerbates Alzheimer's disease pathology in mice. J Neuroinflammation. 2011;8:112.

Lebensmittel- und Futtermittelgesetzbuch (LFGB, 01.09.2005) in der Fassung der Bekanntmachung vom 03.06.2013 (BGBI. I S. 1426), zuletzt geändert durch Art. 28 G v. 20.11.2019 (BGBI. I S. 1626).

Lee AS, Ellman MB, Yan D, Kroin JS, Cole BJ, van Wijnen, Andre J et al. A current review of molecular mechanisms regarding osteoarthritis and pain. Gene. 2013;527(2):440-7.

Lee MS, Trindade MCD, Ikenoue T, Goodman SB, Schurman DJ, Smith RL. Regulation of nitric oxide and bcl-2 expression by shear stress in human osteoarthritic chondrocytes in vitro. J Cell Biochem. 2003;90(1):80-6.

Lemare F, Steimberg N, Le Griel C, Demignot S, Adolphe M. Dedifferentiated chondrocytes cultured in alginate beads: Restoration of the differentiated phenotype and of the metabolic responses to interleukin-1 beta. J Cell Physiol. 1998;176(2):303-13.

Lenox CE, Bauer JE. Potential adverse effects of omega-3 fatty acids in dogs and cats. J Vet Intern Med. 2013;27(2):217-26.

Levin A, Burton-Wurster N, Chen CT, Lust G. Intercellular signaling as a cause of cell death in cyclically impacted cartilage explants. Osteoarthritis Cartilage. 2001;9(8):702-11.

Li H, Wang D, Yuan Y, Min J. New insights on the MMP-13 regulatory network in the pathogenesis of early osteoarthritis. Arthritis Res Ther. 2017;19(1):248. Doi: 10.1186/s13075017-1454-2.

Li X, Ellman M, Muddasani P, Wang JH-C, Cs-Szabo G, van Wijnen AJ et al. PGE(2) and its cognate EP receptors control human adult articular cartilage homeostasis and are linked to the pathophysiology of osteoarthritis. Arthritis Rheum. 2009;60(2):513-23.

Lippiello L. Lipid and cell metabolic changes associated with essential fatty acid enrichment of articular chondrocytes. Proc Soc Exp Biol Med. 1990;195(2):282-7.

Lippiello L, Walsh T, Fienhold M. The association of lipid abnormalities with tissue pathology in human osteoarthritic articular cartilage. Metabolism. 1991;40(6):571-6. 
Lires-Déan M, Caramés B, Cillero-Pastor B, Galdo F, López-Armada MJ, Blanco FJ. Antiapoptotic effect of transforming growth factor-beta 1 on human articular chondrocytes: Role of protein phosphatase 2A. Osteoarthritis Cartilage. 2008;16(11):1370-8.

Little CB, Barai A, Burkhardt D, Smith SM, Fosang AJ, Werb Z et al. Matrix metalloproteinase 13-deficient mice are resistant to osteoarthritic cartilage erosion but not chondrocyte hypertrophy or osteophyte development. Arthritis Rheum. 2009;60(12):3723-33.

Little CB, Hughes CE, Curtis CL, Janusz MJ, Bohne R, Wang-Weigand $S$ et al. Matrix metalloproteinases are involved in C-terminal and interglobular domain processing of cartilage aggrecan in late stage cartilage degradation. Matrix Biol. 2002;21(3):271-88.

Löffler G, Petrides PE, Heinrich PC, Hrsg. Biochemie und Pathobiochemie. 8. Aufl. Berlin Heidelberg: Springer-Verlag; 2007.

Lopez HL. Nutritional interventions to prevent and treat osteoarthritis. Part I: Focus on fatty acids and macronutrients. PM R. 2012;4(5 Suppl):S145-54.

Lotke PA, Granda JL. Alterations in the permeability of articular cartilage by proteolytic enzymes. Arthritis Rheum. 1972;15(3):302-8.

Malemud CJ. Biologic basis of osteoarthritis: State of the evidence. Curr Opin Rheumatol. 2015;27(3):289-94.

Mansfield JC, Winlove CP. Lipid distribution, composition and uptake in bovine articular cartilage studied using Raman micro-spectrometry and confocal microscopy. J Anat. 2017;231(1):156-66. Doi: 10.1111/joa.12624.

Mantzioris E, James MJ, Gibson RA, Cleland LG. Dietary substitution with an alpha-linolenic acid-rich vegetable oil increases eicosapentaenoic acid concentrations in tissues. Am J Clin Nutr. 1994;59(6):1304-9.

Massicotte F, Lajeunesse D, Benderdour M, Pelletier J, Hilal G, Duval N et al. Can altered production of interleukin-1beta, interleukin-6, transforming growth factor-beta and prostaglandin $E(2)$ by isolated human subchondral osteoblasts identify two subgroups of osteoarthritic patients. Osteoarthritis Cartilage. 2002;10(6):491-500.

Mathy-Hartert M, Martin G, Devel P, Deby-Dupont G, Pujol JP, Reginster JY et al. Reactive oxygen species downregulate the expression of pro-inflammatory genes by human chondrocytes. Inflamm Res. 2003;52(3):111-8.

Mclllwraith WC, Frisbie DD, Kawcak CE. The horse as a model of naturally occurring osteoarthritis. Bone Joint Res. 2012;1(11):297-309. Doi: 10.1302/2046-3758.111.2000132. 
Mehler SJ, May LR, King C, Harris WS, Shah Z. A prospective, randomized, double blind, placebo-controlled evaluation of the effects of eicosapentaenoic acid and docosahexaenoic acid on the clinical signs and erythrocyte membrane polyunsaturated fatty acid concentrations in dogs with osteoarthritis. Prostaglandins Leukot Essent Fatty Acids. 2016;109:1-7. Doi: 10.1016/j.plefa.2016.03.015.

Mejiers MHM, Aisa CM, Billingham MEJ, Bunning RAD, Russell RGG. The effect of interleukin-1 beta and transforming growth factor beta on cathepsin B activity in human articular chondrocytes. Agents Actions. 1994;41(Cl):C198-C200.

Melchiorri C, Meliconi R, Frizziero L, Silvestri T, Pulsatelli L, Mazzetti I et al. Enhanced and coordinated in vivo expression of inflammatory cytokines and nitric oxide synthase by chondrocytes from patients with osteoarthritis. Arthritis Rheum. 1998;41(12):2165-74.

Minegishi Y, Hosokawa K, Tsumaki N. Time-lapse observation of the dedifferentiation process in mouse chondrocytes using chrondrocyte-specific reporters. Osteoarthritis Cartilage. 2013;21(12):1968-75

Mitchell JA, Warner TD. Cyclo-oxygenase-2: Pharmacology, physiology, biochemistry and relevance to NSAID therapy. Br J Pharmacol. 1999;128(6):1121-32.

Moghaddami M, James M, Proudman S, Cleland LG. Synovial fluid and plasma $\mathrm{n} 3$ long chain polyunsaturated fatty acids in patients with inflammatory arthritis. Prostaglandins Leukot Essent Fatty Acids. 2015;97:7-12. Doi: 10.1016/j.plefa.2015.02.005.

Mohammed FF, Smookler DS, Khokha R. Metalloproteinases, inflammation, and rheumatoid arthritis. Ann Rheum Dis. 2003;62 Suppl 2:ii43-7.

Monteiro-Steagall BP, Steagall, PVM, Lascelles, BDX. Systematic review of nonsteroidal antiinflammatory drug-induced adverse effects in dogs. J Vet Intern Med. 2013;27(5):1011-9.

Moulharat N, Lesur C, Thomas M, Rolland-Valognes G, Pastoureau P, Anract P et al. Effects of transforming growth factor-beta on aggrecanase production and proteoglycan degradation by human chondrocytes in vitro. Osteoarthritis Cartilage. 2004;12(4):296-305.

Müntener CR, Kupper J, Naegeli H, Schaublin M. Vigilance of veterinary medicinal products: Reports of adverse reactions in the year 2014. Schweiz Arch Tierheilkd. 2015;157(11):601-5.

Murphy CL, Thoms BL, Vaghjiani RJ, Lafont JE. Hypoxia. HIF-mediated articular chondrocyte function: Prospects for cartilage repair. Arthritis Res Ther. 2009;11(1):213. Doi: $10.1186 / a r 2574$.

Murphy $\mathrm{G}$, Lee $\mathrm{MH}$. What are the roles of metalloproteinases in cartilage and bone damage? Ann Rheum Dis. 2005;64(Suppl 4):iv44-iv47. 
Murrell GA, Jang D, Williams RJ. Nitric oxide activates metalloprotease enzymes in articular cartilage. Biochem Biophys Res Commun. 1995;206(1):15-21.

Nagao M, Ishii S, Murata Y, Akino T. Effect of extracellular fatty acids on lipid metabolism in cultured rabbit articular chondrocytes. J Orthop Res. 1991;9(3):341-7.

Nagase $\mathrm{H}$, Kashiwagi M. Aggrecanases and cartilage matrix degradation. Arthritis Res Ther. 2003;5(2):94-103.

Neumann S, Lauenstein-Bosse S. Evaluation of transforming growth factor beta 1 in dogs with osteoarthritis. Open Vet J. 2018;8(4):386-92. Doi: 10.4314/ovj.v8i4.6.

Nicolson GL, Ash ME. Lipid Replacement Therapy: A natural medicine approach to replacing damaged lipids in cellular membranes and organelles and restoring function. Biochim Biophys Acta. 2014;1838(6):1657-79. Doi: 10.1016/j.bbamem.2013.11.010.

Nishitani K, Ito H, Hiramitsu T, Tsutsumi R, Tanida S, Kitaori T et al. PGE2 inhibits MMP expression by suppressing MKK4-JNK MAP kinase-C-JUN pathway via EP4 in human articular chondrocytes. J Cell Biochem. 2010;109(2):425-33.

O'Keefe RJ, Crabb ID, Puzas JE, Rosier RN. Influence of prostaglandins on DNA and matrix synthesis in growth plate chondrocytes. J Bone Miner Res. 1992;7(4):397-404.

O'Neill DG, Church DB, McGreevy PD, Thomson PC, Brodbelt DC. Prevalence of disorders recorded in dogs attending primary-care veterinary practices in England. PLoS One. 2014;9(3):e90501. Doi: 10.1371/journal.pone.0090501.

Ogilvie GK, Fettman MJ, Mallinckrodt CH, Walton JA, Hansen RA, Davenport DJ et al. Effect of fish oil, arginine, and doxorubicin chemotherapy on remission and survival time for dogs with lymphoma: A double-blind, randomized placebo-controlled study. Cancer. 2000;88(8):1916-28.

Oh M, Fukuda K, Asada S, Yasuda Y, Tanaka S. Concurrent generation of nitric oxide and superoxide inhibits proteoglycan synthesis in bovine articular chondrocytes: Involvement of peroxynitrite. J Rheumatol. 1998;25(11):2169-74.

Ontsouka EC, Burgener IA, Luckschander-Zeller N, Blum JW, Albrecht C. Fish-meal diet enriched with omega-3 PUFA and treatment of canine chronic enteropathies. Eur J Lipid Sci Tech. 2012;114(4):412-22.

Ostojic M, Soljic V, Vukojevic K, Dapic T. Immunohistochemical characterization of early and advanced knee osteoarthritis by NF-kappaB and iNOS expression. J Orthop Res. 2017;35(9):1990-7. Doi: 10.1002/jor.23504. 
Palmer RM, Ashton DS, Moncada S. Vascular endothelial cells synthesize nitric oxide from L-arginine. Nature. 1988;333(6174):664-6.

Pan J, Zhou X, Li W, Novotny JE, Doty SB, Wang L. In situ measurement of transport between subchondral bone and articular cartilage. J Orthop Res.2009; 27(10):1347-52.

Pan J, Wang B, Li W, Zhou X, Scherr T, Yang Y et al. Elevated cross-talk between subchondral bone and cartilage in osteoarthritic joints. Bone. 2012;51(2):212-7.

Panina SB, Krolevets IV, Milyutina NP, Sagakyants AB, Kornienko IV, Ananyan AA et al. Circulating levels of proinflammatory mediators as potential biomarkers of post-traumatic knee osteoarthritis development. J Orthop Traumatol. 2017;18(4):349-57. Doi: 10.1007/s10195017-0473-8.

Pelletier JP, Jovanovic DV, Lascau-Coman V, Fernandes JC, Manning PT, Connor JR et al. Selective inhibition of inducible nitric oxide synthase reduces progression of experimental osteoarthritis in vivo: Possible link with the reduction in chondrocyte apoptosis and caspase 3 level. Arthritis Rheum. 2000;43(6):1290-9.

Pettitt RA, German AJ. Investigation and management of canine osteoarthritis. In Pract. 2015;37(Suppl 1):1-8. Doi: 10.1136/inp.h5763.

Pfander D, Heinz N, Rothe P, Carl H-D, Swoboda B. Tenascin and aggrecan expression by articular chondrocytes is influenced by interleukin 1 beta: a possible explanation for the changes in matrix synthesis during osteoarthritis. Ann Rheum Dis. 2004;63(3):240-4.

Pfander D. Physiologie und Pathophysiologie des Gelenkknorpels. Akt Rheumatol. 2005:344-53.

Poole AR, Nelson F, Dahlberg L, Tchetina E, Kobayashi M, Yasuda T et al. Proteolysis of the collagen fibril in osteoarthritis. Biochem Soc Symp. 2003;(70):115-23.

Priddy NH 2 ${ }^{\text {nd }}$, Cook JL, Kreeger JM, Tomlinson JL, Steffen DJ. Effect of ascorbate and two different media on canine chondrocytes in three-dimensional culture. Vet Ther. 2001;2(1):70-7.

Pronost S, Segond N, Macro M, Rédini F, Penfornis H, Jullienne A et al. Modulation of interleukin-1 receptor expression by transforming growth factor-beta in cultured rabbit articular chondrocytes: Analysis by reverse transcription-polymerase chain reaction. Osteoarthritis Cartilage. 1995;3(3):147-55.

Pujol JP, Galera P, Redini F, Mauviel A, Loyau G. Role of cytokines in osteoarthritis: Comparative effects of interleukin 1 and transforming growth factor-beta on cultured rabbit articular chondrocytes. J Rheumatol Suppl. 1991;27:76-9. 
Pujol JP, Chadjichristos C, Legendre F, Baugé C, Beauchef G, Andriamanalijaona R et al. Interleukin-1 and transforming growth factor- $ß 1$ as crucial factors in osteoarthritic cartilage metabolism. Connect Tissue Res. 2008;49(3-4):293-7.

Rai MF, Rachakonda PS, Manning K, Vorwerk B, Brunnberg L, Kohn B et al. Quantification of cytokines and inflammatory mediators in a three-dimensional model of inflammatory arthritis. Cytokine. 2008;42(1):8-17.

Rai MF, Rachakonda PS, Manning K, Palissa C, Sittinger M, Ringe J et al. Molecular and phenotypic modulations of primary and immortalized canine chondrocytes in different culture systems. Res Vet Sci. 2009;87(3):399-407.

Rausch-Derra L, Huebner M, Wofford J, Rhodes L. A prospective, randomized, masked, placebo-controlled multisite clinical study of grapiprant, an EP4 prostaglandin receptor antagonist (PRA), in dogs with osteoarthritis. J Vet Intern Med. 2016;30(3):756-63. Doi: $10.1111 /$ jvim.13948.

Rédini F, Mauviel A, Pronost S, Loyau G, Pujol JP. Transforming growth factor beta exerts opposite effects from interleukin-1 beta on cultured rabbit articular chondrocytes through reduction of interleukin-1 receptor expression. Arthritis Rheum. 1993;36(1):44-50.

Rendal-Vázquez ME, Maneiro-Pampín E, Rodríguez-Cabarcos M, Fernández-Mallo O, López de Ullibarri I, Andión-Núñez $C$ et al. Effect of cryopreservation on human articular chondrocyte viability, proliferation, and collagen expression. Cryobiology. 2001;42(1):2-10.

Richette $\mathrm{P}$, Francois M, Vicaut E, Fitting C, Bardin T, Corvol M et al. A high interleukin 1 receptor antagonist/IL-1beta ratio occurs naturally in knee osteoarthritis. J Rheumatol. 2008;35(8):1650-4.

Ross-Jones TN, Mcllwraith CW, Kisiday JD, Hess TM, Hansen DK, Black J. Influence of an n-3 long-chain polyunsaturated fatty acid-enriched diet on experimentally induced synovitis in horses. J Anim Physiol Anim Nutr (Berl). 2016;100(3):565-77. Doi: 10.1111/jpn.12359.

Roughley PJ, Mort JS. The role of aggrecan in normal and osteoarthritic cartilage. J. Exp. Orthop. 2014;1(1):8. Doi:10.1186/s40634-014-0008-7.

Roush JK, Cross AR, Renberg WC, Dodd CE, Sixby KA, Fritsch DA et al. Evaluation of the effects of dietary supplementation with fish oil omega-3 fatty acids on weight bearing in dogs with osteoarthritis. J Am Vet Med Assoc. 2010a;236(1):67-73.

Roush JK, Dodd CE, Fritsch DA, Allen TA, Jewell DE, Schoenherr WD et al. Multicenter veterinary practice assessment of the effects of omega- 3 fatty acids on osteoarthritis in dogs. J Am Vet Med Assoc. 2010b;236(1):59-66. 
Sandy JD, Flannery CR, Neame PJ, Lohmander LS. The structure of aggrecan fragments in human synovial fluid. Evidence for the involvement in osteoarthritis of a novel proteinase which cleaves the Glu 373-Ala 374 bond of the interglobular domain. J Clin Invest. 1992;89(5):1512-6.

Sandy JD, Chan DD, Trevino RL, Wimmer MA, Plaas A. Human genome-wide expression analysis reorients the study of inflammatory mediators and biomechanics in osteoarthritis. Osteoarthritis Cartilage. 2015;23(11):1939-45.

Sato T, Konomi K, Yamasaki S, Aratani S, Tsuchimochi K, Yokouchi M et al. Comparative analysis of gene expression profiles in intact and damaged regions of human osteoarthritic cartilage. Arthritis Rheum. 2006;54(3):808-17.

Scharstuhl A, Glansbeek HL, van Beuningen HM, Vitters EL, van der Kraan PM, van den Berg WB. Inhibition of endogenous TGF-beta during experimental osteoarthritis prevents osteophyte formation and impairs cartilage repair. J Immunol. 2002;169(1):507-14.

Shen C-L, Dunn DM, Henry JH. Decreased production of inflammatory mediators in human osteoarthritic chondrocytes by conjugated linoleic acids. Lipids. 2004;39:161-6.

Shimpo H, Sakai T, Kondo S, Mishima S, Yoda M, Hiraiwa $H$ et al. Regulation of prostaglandin $E(2)$ synthesis in cells derived from chondrocytes of patients with osteoarthritis. J Orthop Sci. 2009;14(5):611-7.

Shlopov BV, Gumanovskaya ML, Hasty KA. Autocrine regulation of collagenase 3 (matrix metalloproteinase 13) during osteoarthritis. Arthritis Rheum. 2000;43(1):195-205.

Smith CE, Freeman LM, Rush JE, Cunningham SM, Biourge V. Omega-3 fatty acids in Boxer dogs with arrhythmogenic right ventricular cardiomyopathy. $\mathrm{J}$ Vet Intern Med. 2007;21(2):265-73.

Smith MD, Triantafillou S, Parker A, Youssef PP, Coleman M. Synovial membrane inflammation and cytokine production in patients with early osteoarthritis. $J$ Rheumatol. 1997;24(2):365-71.

Smith WL, Urade Y, Jakobsson P. Enzymes of the cyclooxygenase pathways of prostanoid biosynthesis. Chem Rev. 2011;111(10):5821-65. Doi: 10.1021/cr2002992.

Sohn DH, Sokolove J, Sharpe O, Erhart JC, Chandra PE, Lahey LJ et al. Plasma proteins present in osteoarthritic synovial fluid can stimulate cytokine production via Toll-like receptor 4. Arthritis Res Ther. 2012;14(1):R7. Doi: 10.1186/ar3555.

Stockwell RA. The lipid and glycogen content of rabbit articular hyaline and non-articular hyaline cartilage. J Anat. 1967;102(Pt 1):87-94. 
Stratman NC, Carter DB, Sethy VH. Ibuprofen: Effect on inducible nitric oxide synthase. Brain Res Mol Brain Res. 1997;50(1-2):107-12.

Studer RK, Levicoff E, Georgescu H, Miller L, Jaffurs D, Evans CH. Nitric oxide inhibits chondrocyte response to IGF-I: Inhibition of IGF-IR $\beta$ tyrosine phosphorylation. Am J Physiol Cell Physiol. 2000;279(4):C961-C969.

Su S, Grover J, Roughley PJ, DiBattista JA, Martel-Pelletier J, Pelletier JP et al. Expression of the tissue inhibitor of metalloproteinases (TIMP) gene family in normal and osteoarthritic joints. Rheumatol Int. 1999;18(5-6):183-91.

Szabo SD, Biery DN, Lawler DF, Shofer FS, Powers MY, Kealy RD et al. Evaluation of a circumferential femoral head osteophyte as an early indicator of osteoarthritis characteristic of canine hip dysplasia in dogs. J Am Vet Med Assoc. 2007;231(6):889-92.

Tallheden T, Brittberg M, Peterson L, Lindahl A. Human articular chondrocytes-plasticity and differentiation potential. Cells Tissues Organs. 2006;184(2):55-67.

Tang QO, Shakib K, Heliotis M, Tsiridis E, Mantalaris A, Ripamonti U. TGF-beta 3: A potential biological therapy for enhancing chondrogenesis. Expert Opin Biol Ther. 2009;9(6):689-701.

Taskiran D, Stefanovic-Racic M, Georgescu H, Evans C. Nitric oxide mediates suppression of cartilage proteoglycan synthesis by interleukin-1. Biochem Biophys Res Commun. 1994;200(1):142-8.

Tchetina EV, Antoniou J, Tanzer M, Zukor DJ, Poole AR. Transforming growth factor-beta2 suppresses collagen cleavage in cultured human osteoarthritic cartilage, reduces expression of genes associated with chondrocyte hypertrophy and degradation, and increases prostaglandin $E(2)$ production. Am J Pathol. 2006;168(1):131-40.

Tchetina EV, Di Battista JA, Zukor DJ, Antoniou J, Poole AR. Prostaglandin PGE(2) at very low concentrations suppresses collagen cleavage in cultured human osteoarthritic articular cartilage: This involves a decrease in expression of proinflammatory genes, collagenases and COL10A1, a gene linked to chondrocyte hypertrophy. Arthritis Res Ther. 2007;9(4):R75. Doi: 10.1186/ar2273.

Temenoff JS, Mikos AG. Review: Tissue engineering for regeneration of articular cartilage. Biomaterials. 2000;21(5):431-40.

Tetlow LC, Adlam DJ, Woolley DE. Matrix metalloproteinase and proinflammatory cytokine production by chondrocytes of human osteoarthritic cartilage: Associations with degenerative changes. Arthritis Rheum. 2001;44(3):585-94. 
Tortorella MD, Malfait A-M, Deccico C, Arner E. The role of ADAM-TS4 (aggrecanase-1) and ADAM-TS5 (aggrecanase-2) in a model of cartilage degradation. Osteoarthritis Cartilage. 2001;9(6):539-52.

Tsuchida Al, Beekhuizen M, 't Hart MC, Radstake TR, Dhert WJA, Saris DBF et al. Cytokine profiles in the joint depend on pathology, but are different between synovial fluid, cartilage tissue and cultured chondrocytes. Arthritis Res Ther. 2014;16(5). Doi: 10.1186/s13075-0140441-0.

van den Berg WB. Osteoarthritis year 2010 in review: Pathomechanisms. Osteoarthritis Cartilage. 2011;19(4):338-41.

van der Kraan PM. Age-related alterations in TGF beta signaling as a causal factor of cartilage degeneration in osteoarthritis. Biomed Mater Eng. 2014;24(1 Suppl):75-80.

VanderSluis L, Mazurak VC, Damaraju S, Field CJ. Determination of the relative efficacy of eicosapentaenoic acid and docosahexaenoic acid for anti-cancer effects in human breast cancer models. Int J Mol Sci. 2017;18(12). Doi: 10.3390/ijms18122607.

Vandeweerd J-M, Coisnon C, Clegg P, Cambier C, Pierson A, Hontoir F et al. Systematic review of efficacy of nutraceuticals to alleviate clinical signs of osteoarthritis. J Vet Intern Med. 2012;26(3):448-56.

VERORDNUNG (EG) Nr. 767/2009 des europäischen Parlaments und Rates vom 13.07.2009 über das Inverkehrbringen und die Verwendung von Futtermitteln. ABI 01.09.2009; L229/2.

Verpaalen VD, Baltzer WI, Smith-Ostrin S, Warnock JJ, Stang B, Ruaux CG. Assessment of the effects of diet and physical rehabilitation on radiographic findings and markers of synovial inflammation in dogs following tibial plateau leveling osteotomy. J Am Vet Med Assoc. 2018;252(6): 701-706.

Villalvilla A, Gómez R, Largo R, Herrero-Beaumont G. Lipid transport and metabolism in healthy and osteoarthritic cartilage. Int J Mol Sci. 2013;14(10):20793-808.

Vuolteenaho K, Moilanen T, Jalonen U, Lahti A, Nieminen R, van Beuningen HM et al. TGF beta inhibits IL-1 -induced iNOS expression and NO production in immortalized chondrocytes. Inflamm Res. 2005;54(10):420-7.

Wang P, Guan P, Guo C, Zhu F, Konstantopoulos K, Wang Z. Fluid shear stress-induced osteoarthritis: Roles of cyclooxygenase-2 and its metabolic products in inducing the expression of proinflammatory cytokines and matrix metalloproteinases. FASEB J. 2013;27(12):4664-77. Doi: 10.1096/fj.13-234542. 
Wang $\mathrm{X}$, Hunter $\mathrm{D}, \mathrm{Xu} \mathrm{J}$, Ding C. Metabolic triggered inflammation in osteoarthritis. Osteoarthritis Cartilage. 2015;23(1):22-30.

Wang Y, Wei L, Zeng L, He D, Wei X. Nutrition and degeneration of articular cartilage. Knee Surg Sports Traumatol Arthrosc. 2013;21(8):1751-62. Doi: 10.1007/s00167-012-1977-7.

Wann AKT, Mistry J, Blain EJ, Michael-Titus AT, Knight MM. Eicosapentaenoic acid and docosahexaenoic acid reduce interleukin-1 $\beta$-mediated cartilage degradation. Arthritis Res Ther. 2010;12(6):R207. Doi: 10.1186/ar3183.

Westacott Cl, Sharif M. Cytokines in osteoarthritis: Mediators or markers of joint destruction? Semin Arthritis Rheum. 1996;25(4):254-72.

Weylandt KH, Chiu C, Gomolka B, Waechter SF, Wiedenmann B. Omega-3 fatty acids and their lipid mediators: Towards an understanding of resolvin and protectin formation. Prostaglandins Other Lipid Mediat. 2012;97(3-4):73-82. Doi: 10.1016/j.prostaglandins.2012.01.005.

Whiteman M, Armstrong JS, Cheung NS, Siau J-L, Rose P, Schantz JT et al. Peroxynitrite mediates calcium-dependent mitochondrial dysfunction and cell death via activation of calpains. FASEB J. 2004;18(12):1395-7. Doi: 10.1096/fj.03-1096fje.

Wojdasiewicz P, Poniatowski ŁA, Szukiewicz D. The role of inflammatory and antiinflammatory cytokines in the pathogenesis of osteoarthritis. Mediators Inflamm. 2014;2014:19 pages. Doi: 10.1155/2014/561459.

Wong M, Carter DR. Articular cartilage functional histomorphology and mechanobiology: A research perspective. Bone. 2003;33(1):1-13.

Xia B, Chen D, Zhang J, Hu S, Jin H, Tong P. Osteoarthritis pathogenesis: A review of molecular mechanisms. Calcif Tissue Int. 2014;95(6):495-505. Doi: 10.1007/s00223-0149917-9.

Xu H, Watkins A, Adkisson HD. Dietary lipids modify the fatty acid composition of cartilage, isolated chondrocytes and matrix vesicles. Lipids. 1994;29(9):619-25.

Yasuhara R, Miyamoto Y, Akaike T, Akuta T, Nakamura M, Takami M et al. Interleukin-1beta induces death in chondrocyte-like ATDC5 cells through mitochondrial dysfunction and energy depletion in a reactive nitrogen and oxygen species-dependent manner. Biochem J. 2005;389(2):315-23.

Yu WH, Yu S, Meng Q, Brew K, Woessner JF Jr. TIMP-3 binds to sulfated glycosaminoglycans of the extracellular matrix. J Biol Chem. 2000;275(40):31226-32. 
Zainal Z, Longman AJ, Hurst S, Duggan K, Caterson B, Hughes CE et al. Relative efficacies of omega-3 polyunsaturated fatty acids in reducing expression of key proteins in a model system for studying osteoarthritis. Osteoarthritis Cartilage. 2009;17(7):896-905.

Zhai G, Doré J, Rahman P. TGF-beta signal transduction pathways and osteoarthritis. Rheumatol Int. 2015;35(8):1283-92. Doi: 10.1007/s00296-015-3251-z.

Zhang Z, McCaffery JM, Spencer RGS, Francomano CA. Hyaline cartilage engineered by chondrocytes in pellet culture: Histological, immunohistochemical and ultrastructural analysis in comparison with cartilage explants. J Anat. 2004;205(3):229-37.

Zhao T, Xia Y, Li L, Li J, Zhu G, Chen S et al. Bovine serum albumin promotes IL-1beta and TNF-alpha secretion by N9 microglial cells. Neurol Sci. 2009;30(5):379-83.

Zhao W, Wang T, Luo Q, Chen Y, Leung VYL, Wen C et al. Cartilage degeneration and excessive subchondral bone formation in spontaneous osteoarthritis involves altered TGF-beta signaling. J Orthop Res. 2016;34(5):763-70. Doi: 10.1002/jor.23079. 


\section{DANKSAGUNG}

Mein Dank gilt zunächst meinem Doktorvater Prof. Dr. Herbert Fuhrmann, der mir dieses hochinteressante Thema übertragen hat und mich herzlich in sein Forschungsteam aufgenommen hat. Jede Phase dieser Arbeit wurde von ihm professionell und warmherzig begleitet. Besonders danken möchte ich inm für seine ausgesprochene Geduld und sein Verständnis, da die Fertigstellung dieser Arbeit neben dem stressigen Klinikjob bewältigt werden musste.

Großer Dank gebührt meinem Zweitbetreuer und Zimmernachbar Dr. Axel Schöniger. Nicht nur, dass er mir immer mit seinem kompetenten Rat zur Seite stand, auch musste er fast täglich meine Zweifel zerschlagen und hat mich oft mit engelsgleicher Geduld ermutigt, nicht aufzugeben. Ohne seine Hilfe wäre diese Arbeit so nicht zu Stande gekommen.

Für die unermüdliche und professionelle Einführung in sämtliche Zellkulturarbeiten danke ich Frau Büchner ganz herzlich. Frau Dobeleit danke ich für die ausgezeichnete Unterstützung bei der Untersuchung und Auswertung der Gaschromatographie. Unsere zahlreichen interessanten Gespräche zu Nahrungsergänzungsmitteln haben nicht nur diese Arbeit, sondern auch meine Kochrezepte bereichert.

Besonderer Dank gilt auch unserer Sekretärin Frau Gück, der guten Seele des Instituts, welche stets ein offenes Ohr für mich hatte und in jeder Lebenslage unterstützenden Beistand leistete.

Ich danke meinen Mitdoktoranden Alexander Gleich, Christine Hellwing und Bastian Kaiser sowie allen Mitarbeitern und Mitarbeiterinnen des Veterinär-PhysiologischChemischen Instituts für die außerordentlich gute Zusammenarbeit. Nur durch ihre Hilfe ist es mir gelungen, mich in dieses eigentlich fachfremde Gebiet einzuarbeiten und diese Arbeit zur realisieren.

Ein besonderer Dank geht an meine Eltern und Großeltern, die mir das Studium der Veterinärmedizin ermöglichten und auch während der Anfertigung dieser Arbeit immerzu unterstützend und liebevoll zur Seite standen. Ich danke besonders meinen Großeltern Marlene und Andreas Deutrich dafür, dass ich jederzeit bei ihnen Zuflucht finden konnte und sie mich in jeder Not mit leckerem Essen und tiefgreifenden Gesprächen wieder aufzubauen wussten. 
Mein größter Dank gilt jedoch meiner besten Freundin und Mitbewohnerin Franziska Koch, die sowohl mein Studium als auch meine Arbeit an der Universität über den gesamten Zeitraum begleitet hat. Unsere Mensa-Gespräche halfen mir aus so mancher Krise und ohne ihre Hilfe hätte ich sicher bald aufgegeben. Kannst du es glauben, dass wir es wirklich geschafft haben?

Bei Boehringer Ingelheim bedanke ich mich für die finanzielle Unterstützung dieser Arbeit und sowie das Sponsoring des Besuches des BSAVA Kongress in Birmingham 2011. 